Supporting Information

Part 1

\title{
Modular solid-phase synthesis of antiprotozoal barnesin derivatives
}

Dávid Romana, Luka Raguža, Francois Keiffa, Florian Meyera, Fabian Barthels ${ }^{\mathrm{b}}$, Tanja Schirmeisterb ${ }^{\text {, Florian Kloss, }{ }^{\text {a }} \text { Christine Beemelmanns }}{ }^{a}$

aLeibniz Institute for Natural Product Research and Infection Biology - Hans Knöll Institute, Beutenbergstraße 11a, 07745 Jena, Germany

bInstitute of Pharmacy and Biochemistry, Johannes Gutenberg University Mainz, Staudingerweg 5, D55128, Mainz

Corresponding Author

E-mail: christine.beemelmanns@hki-jena.de 


\section{Content}

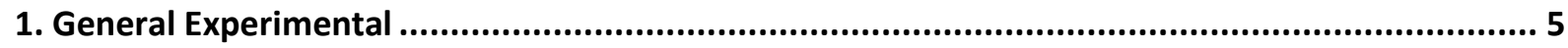

2. Experimental Procedures and Characterization Data for ........................................................ 6

2.1 General procedure for the synthesis of triple protected arginine ${ }^{2}$ (GP1) ............................... 6

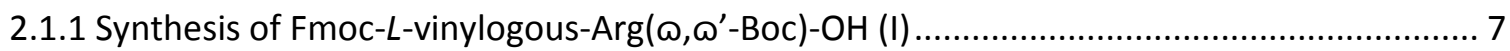

2.1.2 Synthesis of Fmoc-D-vinylogous-Arg( $\left(, \mathrm{Q}^{\prime}-\mathrm{Boc}\right)-\mathrm{OH}$ (II) ................................................... 7

2.2 General procedure for the methyl ester formation (GP2) ….................................................. 7

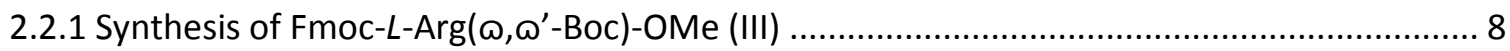

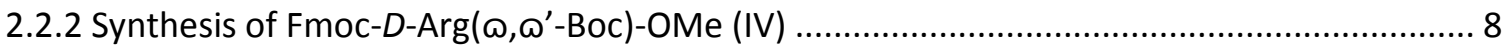

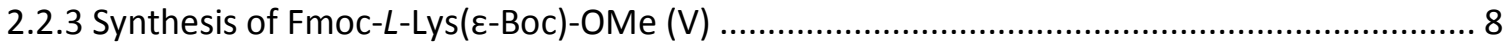

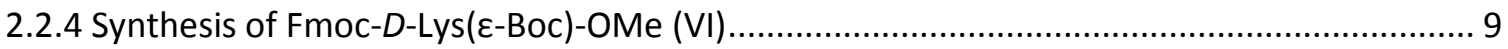

2.3 General procedure for the reduction of methyl esters ${ }^{4}$ (GP3) ............................................. 9

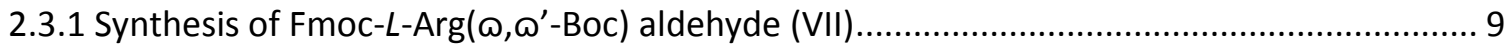

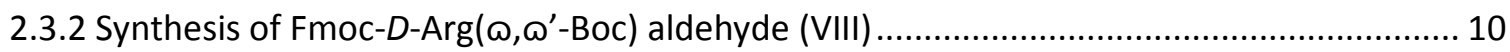

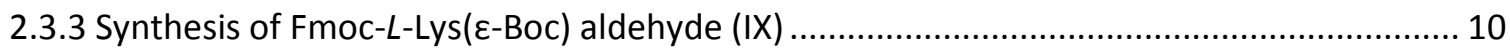

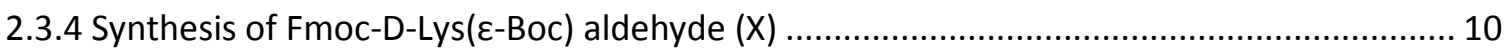

3. General procedure for solid-phase peptide synthesis (GP4) .............................................. 11

4. General procedure for the esterification of the C-terminus (GP5) ........................................... 13

5. Experimental Procedures of SPPS and Analytical Data .......................................................... 14

5.1 (S,E)-7-guanidino-4-((S)-3-(4-hydroxyphenyl)-2-((E)-oct-2-enamido)propanamido)hep-2-enoic

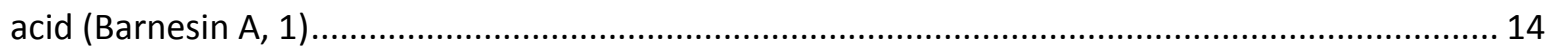

$5.2(R, E)$-7-guanidino-4-((S)-3-(4-hydroxyphenyl)-2-((E)-oct-2-enamido)propanamido)hept-2-

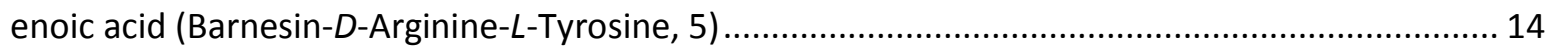

5.3 (S,E)-7-guanidino-4-((R)-3-(4-hydroxyphenyl)-2-((E)-oct-2-enamido)propanamido)hept-2-

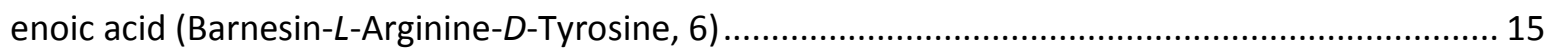

5.4 (S,E)-7-guanidino-4-((S)-3-(4-hydroxyphenyl)-2-stearamidopropanamido)hept-2-enoic acid (Barnesin-L-Arginine-L-Tyrosine-stearic acid, 7)

5.5 (S,E)-7-guanidino-4-((S)-3-(4-hydroxyphenyl)-2-octanamidopropanamido)hept-2-enoic acid (17,18-Dihydrobarnesin, 8)

$5.6(S, E)-4-((S)$-2-((E)-but-2-enamido)-3-(4-hydroxyphenyl)propanamido)-7-guanidinohept-2enoic acid (Barnesin-trans-2-butenoic acid, 9)

$5.7(S, E)$-4-((S)-2-acetamido-3-(4-hydroxyphenyl)propanamido)-7-guanidinohept-2-enoic acid (Acylderivative, 10).

5.8 (S)-7-guanidino-4-((S)-3-(4-hydroxyphenyl)-2-octanamidopropanamido)heptanoic acid $(2,3,17,18-$ Tetrahydro Barnesin, 11)

5.9 (S,E)-7-guanidino-4-((S)-2-((E)-oct-2-enamido)-3-phenylpropanamido)hept-2-enoic acid (Barnesin-L-Phenylalanine, 12)... 
5.10 Methyl (S,E)-8-amino-4-((S)-3-(4-hydroxyphenyl)-2-((E)-oct-2-enamido)propanamido)oct-2enoate (Barnesin-L-Lysin-OMe, 13)

5.11 Methyl (S,E)-8-amino-4-((S)-2-((E)-oct-2-enamido)-3-phenylpropanamido)oct-2-enoate (Barnesin-L-Lysin-OMe-L-Phenylalanine, 14)

5.12 (S,E)-8-amino-4-((S)-2-((E)-oct-2-enamido)-3-phenylpropanamido)oct-2-enoic acid (Barnesin-L-Lysin-L-Phenylalanine, 15) ....

$5.13(S, E)$-8-amino-4-((S)-3-(4-hydroxyphenyl)-2-((E)-oct-2-enamido)propanamido)oct-2-enoic acid (Barnesin-L-Lysin, 16)

5.14 (R,E)-8-amino-4-((S)-3-(4-hydroxyphenyl)-2-((E)-oct-2-enamido)propanamido)oct-2-enoic acid (Barnesin- $D$-Lysin, 17).

6. Bioactivity studies

6.1 Enzymatic assays

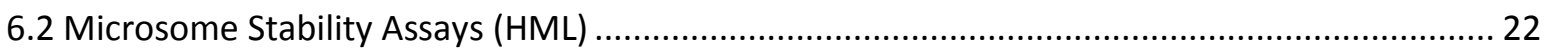

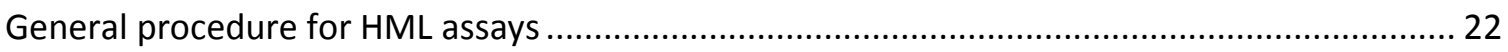

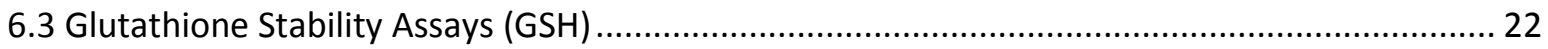

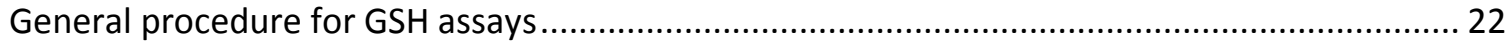

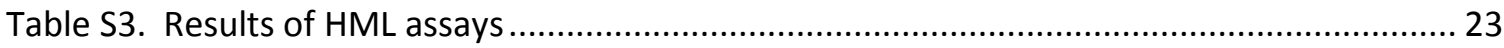

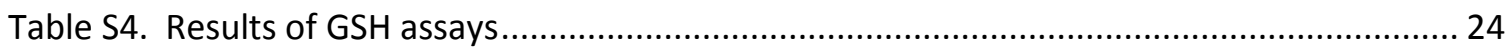

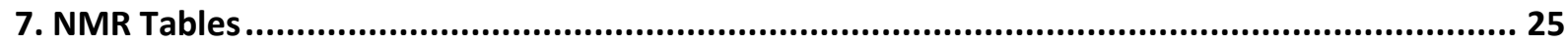

Table S5. NMR table of (S,E)-7-guanidino-4-((S)-3-(4-hydroxyphenyl)-2-((E)-oct-2enamido)propanamido)hep-2-enoic acid (Barnesin $\mathrm{A}, 1)$ in $d_{6}$-DMSO at $26^{\circ} \mathrm{C}$.

Table S6. NMR table of (R,E)-7-guanidino-4-((S)-3-(4-hydroxyphenyl)-2-((E)-oct-2enamido)propanamido)hept-2-enoic acid (Barnesin-D-Arginine-L-Tyrosine, 5) ) in $d_{6}$-DMSO at $26^{\circ} \mathrm{C}$

Table S7. NMR Table of $(S, E)$-7-guanidino-4-((R)-3-(4-hydroxyphenyl)-2-((E)-oct-2-

enamido)propanamido)hept-2-enoic acid (Barnesin-L-Arginine-D-Tyrosine, 6 ) in $d_{6}$-DMSO at $26^{\circ} \mathrm{C}$

Table S8. NMR table of (S,E)-7-guanidino-4-((S)-3-(4-hydroxyphenyl)-2-

stearamidopropanamido)hept-2-enoic acid (Barnesin-L-Arginine-L-Tyrosine-stearic acid, 7) in $d_{6^{-}}$ DMSO at $26^{\circ} \mathrm{C}$.

Table S10. NMR table of (S,E)-4-((S)-2-((E)-but-2-enamido)-3-(4-hydroxyphenyl)propanamido)-7guanidinohept-2-enoic acid (Barnesin-trans-2-butenoic acid, 9) in $d_{6}$-DMSO at $26^{\circ} \mathrm{C}$.................... 30

Table S11. NMR table of $(S, E)$-4-((S)-2-acetamido-3-(4-hydroxyphenyl)propanamido)-7guanidinohept-2-enoic acid (Acylderivative, 10) in $d_{6}$-DMSO at $26{ }^{\circ} \mathrm{C}$

Table S12. NMR table of (S)-7-guanidino-4-((S)-3-(4-hydroxyphenyl)-2octanamidopropanamido)heptanoic acid $(2,3,17,18$-Tetrahydro Barnesin, 11$)$ in $d_{6}$-DMSO at $26^{\circ} \mathrm{C}$

Table S13. NMR table of (S,E)-7-guanidino-4-((S)-2-((E)-oct-2-enamido)-3phenylpropanamido)hept-2-enoic acid (Barnesin-L-Phenylalanine, 12 ) in $d_{6}$-DMSO at $26^{\circ} \mathrm{C}$ 33 
Table S14. NMR table of methyl (S,E)-8-amino-4-((S)-3-(4-hydroxyphenyl)-2-((E)-oct-2enamido)propanamido)oct-2-enoate (Barnesin-L-Lysin-OMe, 13) in $d_{6}$-DMSO at $26{ }^{\circ} \mathrm{C}$.

Table S15. NMR table of methyl $(S, E)$-8-amino-4-((S)-2-((E)-oct-2-enamido)-3-

phenylpropanamido)oct-2-enoate (Barnesin-L-Lysin-OMe-L-Phenylalanine, 14) in $d_{6}$-DMSO at $26{ }^{\circ} \mathrm{C}$

Table S16. NMR table of (S,E)-8-amino-4-((S)-2-((E)-oct-2-enamido)-3-phenylpropanamido)oct-2enoic acid (Barnesin-L-Lysin-L-Phenylalanine, 15$)$ in $d_{6}$-DMSO at $26^{\circ} \mathrm{C}$

Table S17. NMR table of $(S, E)$-8-amino-4-((S)-3-(4-hydroxyphenyl)-2-((E)-oct-2-

enamido)propanamido)oct-2-enoic acid (Barnesin-L-Lysin, 16) in $\mathrm{D}_{2} \mathrm{O}$ at $26{ }^{\circ} \mathrm{C}$

Table S18. NMR table of $(R, E)$-8-amino-4-((S)-3-(4-hydroxyphenyl)-2-((E)-oct-2-

enamido)propanamido)oct-2-enoic acid (Barnesin-D-Lysin, 17) in $d_{6}$-DMSO at $26^{\circ} \mathrm{C}$

8. References

39 


\section{General Experimental}

NMR measurements were performed on a Bruker AVANCE II $300 \mathrm{MHz}$, Bruker AVANCE $500 \mathrm{MHz}$ and a Bruker AVANCE III $600 \mathrm{MHz}$ spectrometer, equipped with a Bruker Cryoplatform. The chemical shifts are reported in parts per million (ppm) relative to the solvent residual peak of DMSO-d6 $\left({ }^{1} \mathrm{H}\right.$ : 2.50 ppm, quintet; ${ }^{13} \mathrm{C}: 39.52 \mathrm{ppm}$, septet), $\mathrm{CDCl}_{3}\left({ }^{1} \mathrm{H}: 7.26 \mathrm{ppm}\right.$, singlet; ${ }^{13} \mathrm{C}: 77.16 \mathrm{ppm}$, triplet), $\mathrm{D}_{2} \mathrm{O}$ $\left({ }^{1} \mathrm{H}: 4.79 \mathrm{ppm}\right)$. The following abbreviations were used to explain multiplicities: $\mathrm{s}=$ singlet, $d=$ doublet, $\mathrm{t}=$ triplet, $\mathrm{q}=$ quartet, $\mathrm{dd}=$ doublet of doublets, $\mathrm{dt}=$ doublet of triplets, $\mathrm{m}=$ multiplet, $\mathrm{br}=$ broad.

LC-ESI-HRMS measurements were carried out on an Accela UPLC system (Thermo Scientific) coupled with a Phenomenex Kinetex C18 column (150 x $2.1 \mathrm{~mm}$, particle size $2.6 \mu \mathrm{m})$ combined with a QExactive mass spectrometer (Thermo Scientific) equipped with an electrospray ion (ESI) source.

UHPLC-MS measurements were performed on a Shimadzu LCMS-2020 system equipped with single quadrupole mass spectrometer using a Phenomenex Kinetex $\mathrm{C} 18$ column $(50 \times 2.1 \mathrm{~mm}$, particle size $1.7 \mu \mathrm{m}$, pore diameter $100 \AA$ ). Column oven was set to $40 \mathrm{C}$; scan range of MS was set to $\mathrm{m} / \mathrm{z} 150$ to 2,000 with a scan speed of $10,000 \mathrm{u} / \mathrm{s}$ and event time of $0.25 \mathrm{~s}$ under positive and negative mode. DL temperature was set to $250^{\circ} \mathrm{C}$ with an interface temperature of $350{ }^{\circ} \mathrm{C}$ and a heat block of $400{ }^{\circ} \mathrm{C}$. The nebulizing gas flow was set to $1.5 \mathrm{~L} / \mathrm{min}$ and dry gas flow to $15 \mathrm{~L} / \mathrm{min}$.

Semi-preparative HPLC was performed on a Shimadzu HPLC system using a Phenomenex Luna C18(2) column (particle size $5 \mu \mathrm{m}$, pore diameter $100 \AA$ ).

Flash chromatography purification was performed on a Biotage Isolera Prime system. Normal phase purifications were run on packed Biotage SNAP KP-Sil cartridges ( $25 \mathrm{~g}, 40 \mathrm{~g}, 80 \mathrm{~g}, 120 \mathrm{~g}$ and $200 \mathrm{~g}$ ) or on Biotage cartridges packed with Normasil 60 silica gel (particle size $40-63 \mu \mathrm{m})(25 \mathrm{~g}$, and $40 \mathrm{~g}$ ) using cyclohexane and EtOAc as solvents, unless otherwise stated. Reverse phase purifications were run on packed Biotage SNAP Ultra C18 column (12 g) using a $\mathrm{MeOH}$ and $\mathrm{H}_{2} \mathrm{O}$ with $0.1 \% \mathrm{AcOH}$ gradient for reverse phase.

IR spectra were recorded on an FT/IR-4100 ATR spectrometer (JASCO).

Optical rotations were recorded in $\mathrm{MeOH}$ on a $\mathrm{P}-1020$ polarimeter (JASCO).

TLC was performed using $0.25 \mathrm{~mm}$ Macherey-Nagel silica plates with Fluorescent indicator $\mathrm{UV}_{254}$, using short-wave UV light as the visualizing agent, and $p$-anisaldehyde and heat as developing agents. Reactions were monitored by LC/MS and thin layer chromatography (TLC).

Solid-phase peptide synthesis was performed using 2-Chlorotrityl Chloride resin (CTC resin) purchased from Carbolution Chemicals and used without further purification.

Kaiser test ${ }^{1}$ was performed using one drop of a $5 \%$ solution ninhydrin in $\mathrm{EtOH}$, one drop of a $20 \mu \mathrm{M}$ $\mathrm{KCN}$ solution in pyridine and one drop of a $5 \%$ phenol solution in EtOH which were placed in a HPLC vial. An analytical amount of the resin was added to the mixture. The vial was closed and incubated at $100{ }^{\circ} \mathrm{C}$ for 5 minutes. A negative response led to the remaining yellow colour of the solution. The solution coloured dark blue in presence of free primary amines.

All other reagents and solvents for synthesis were purchased from Acros Organics, Alfa Aesar, Carbolution Chemicals, Carl Roth, Sigma Aldrich, TCl, Th. Geyer, VWR in the highest commercial quality and used without further purification, unless otherwise stated. 


\section{Experimental Procedures and Characterization Data for}

\subsection{General procedure for the synthesis of triple protected arginine ${ }^{2}$ (GP1)}

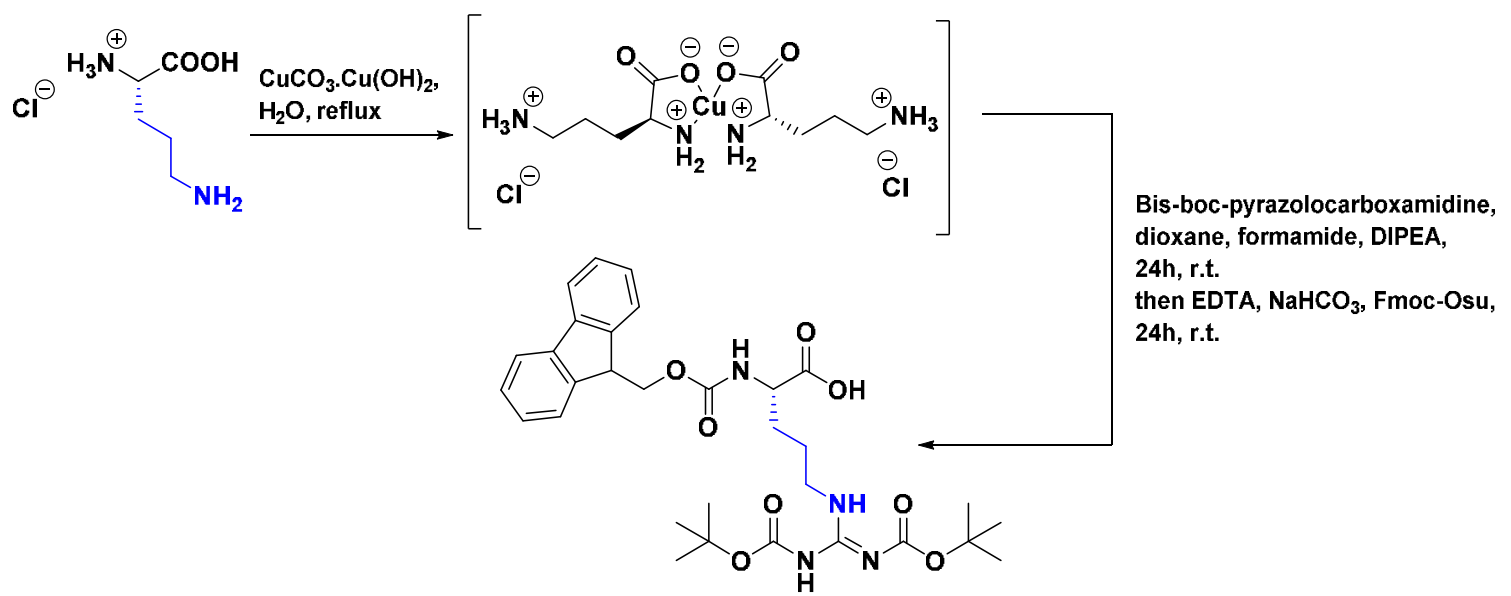

A mixture containing $D$ - or $L$-ornithine hydrochloride (1.0 eq.) and basic copper carbonate $\mathrm{CuCO}_{3}$ (0.5 eq.) was dissolved in distilled $\mathrm{H}_{2} \mathrm{O}$ (8 $\mathrm{mL}$ per $1 \mathrm{~g}$ of ornithine) and stirred under reflux for $15 \mathrm{~min}$. The blue reaction mixture was filtered, evaporated and dried under reduced pressure to afford a blue solid.

The intermediate was suspended in formamide $(6 \mathrm{~mL}$ ) and DIPEA (4.5 eq.) was added. To the blue solution was added dropwise bis-boc-pyrazolocarboxamidine (2.0 eq.) in dioxane (3.3 mL per 1.0 eq.). The reaction mixture was stirred at r.t. overnight, then quenched with $\mathrm{H}_{2} \mathrm{O}(20 \mathrm{~mL})$ to yield a light blue solid precipitate. The suspension was extracted twice with EtOAc $(2 \times 30 \mathrm{~mL})$. Organic layers were combined, washed with brine, dried over $\mathrm{MgSO}_{4}$, filtered and concentrated in vacuo to give a blue foam.

The crude product was suspended in $\mathrm{H}_{2} \mathrm{O}(10 \mathrm{~mL})$, EDTA* $2 \mathrm{Na}^{2} 2 \mathrm{H}_{2} \mathrm{O}$ (1.2 eq.) and saturated aq. $\mathrm{NaHCO}_{3}$ (4.7 eq.) were added. Then 9-fluorenylmethyl-succinimidyl carbonate (3.0 eq.) dissolved in acetone ( $9 \mathrm{~mL}$ per 1.0 eq.) was added dropwise to the reaction mixture at room temperature. The blue suspension turned light blue and the reaction mixture was stirred overnight. Subsequently, the solvent was removed under reduced pressure, $\mathrm{H}_{2} \mathrm{O}(25 \mathrm{~mL})$ was added resulting in a slight basic light blue turbid mixture $(\mathrm{pH} 8)$. The mixture was acidified by $10 \%$ aq. citric acid solution $(\mathrm{pH} \mathrm{2-3).}$ The resulting solution was extracted twice with EtOAc $(2 \times 30 \mathrm{~mL})$. Organic layers were combined, washed with brine, dried over MgSO4, filtered and concentrated in vacuo.

The crude product was purified by flash chromatography over a silica gel column (mobile phase: cyclohexane/EtOAc $+1 \% \mathrm{AcOH}$ 10:1 to $1: 1$ ). The appropriate fractions were collected, combined and concentrated under vacuo to give a triple protected arginine. 


\subsubsection{Synthesis of Fmoc-L-vinylogous-Arg(Ф,ه'-Boc)-OH (I)}

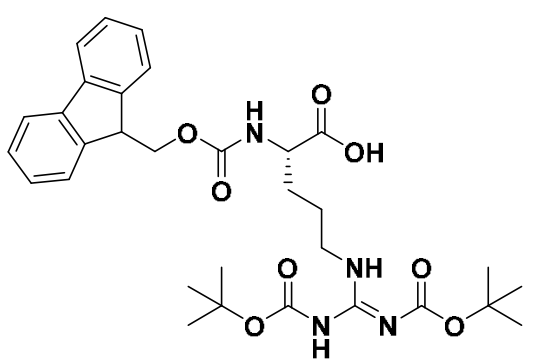

Following GP1 with L-ornithine hydrochloride $(11.9 \mathrm{mmol})$ yielded I (3800mg, $74 \%$ ) as colorless foam.

${ }^{1} \mathrm{H}-\mathrm{NMR}\left(300 \mathrm{MHz}, \mathrm{CDCl}_{3}\right): \delta=1.48\left(\mathrm{~s}, 9 \mathrm{H}, \mathrm{NHCO}_{2} \underline{\mathrm{tBu}}\right), 1.49(\mathrm{~s}$, $\left.9 \mathrm{H}, \mathrm{NHCO}_{2} \underline{\mathrm{tBu}}\right), 1.80-1.66\left(\mathrm{~m}, 3 \mathrm{H}, 3-\mathrm{H}_{\mathrm{B}}, 4-\mathrm{H}\right), 2.01-1.90(\mathrm{~m}$, $\left.1 \mathrm{H}, 3-\mathrm{H}_{\mathrm{A}}\right), 3.49-3.37(\mathrm{~m}, 2 \mathrm{H}, 5-\mathrm{H}), 4.22(\mathrm{t}, J=7.0 \mathrm{~Hz}, 1 \mathrm{H}, 9-\mathrm{H})$, $4.41(\mathrm{~d}, J=7.0 \mathrm{~Hz}, 8-\mathrm{H}), 4.46-4.37(\mathrm{~m}, 1 \mathrm{H}, 2-\mathrm{H}), 5.81(\mathrm{~d}, J=8.1$ $\mathrm{Hz}, 1 \mathrm{H}, \mathrm{NH}(2)), 7.30\left(\mathrm{td}, J_{d}=1.1 \mathrm{~Hz}, J_{t}=7.4 \mathrm{~Hz}, 2 \mathrm{H}, 12-\mathrm{H}\right), 7.40$ (t, $J=7.4 \mathrm{~Hz}, 13-\mathrm{H}), 7.74-7.63(\mathrm{~m}, 2 \mathrm{H}, 11-\mathrm{H}), 7.76(\mathrm{~d}, J=7.4 \mathrm{~Hz}, 2 \mathrm{H}, 14-\mathrm{H}), 8.44$ (br. $\mathrm{s}, 1 \mathrm{H}, \mathrm{N} \underline{\mathrm{H}}(1))$, 11.40 (br. s, $1 \mathrm{H}, \mathrm{NHCO}_{2} t \mathrm{Bu}$ ) ppm.

${ }^{13}$ C-NMR (125 MHz, $\left.\mathrm{CDCl}_{3}\right): \delta=25.3^{*}, 25.5,28.2,28.3,28.4^{*}, 29.7,29.8^{*}, 40.4^{*}, 40.6,47.3,53.7$, 54.1*, 67.1, 67.3*, 79.7*, 80.1, 80.5*, 83.4, 83.7*, 84.3, 120.1, 124.9*, 125.3, 127.2, 127.8, 141.4, $143.8,144.0^{*}, 152.9^{*}, 153.3,156.4,156.4,156.6^{*}, 162.8,163.3^{*}, 172.5^{*}, 174.9$ ppm, *minor rotamers.

HRMS (ESI-TOF): calculated for $\mathrm{C}_{31} \mathrm{H}_{41} \mathrm{O}_{8} \mathrm{~N}_{4}[\mathrm{M}+\mathrm{H}]^{+}$597.2919; found 597.2917.

\subsubsection{Synthesis of Fmoc-D-vinylogous-Arg( $\left(, \Phi^{\prime}-\mathrm{Boc}\right)-\mathrm{OH}$ (II)}<smiles>CC(C)(C)OC(=O)N=C(NCCCC(NC(=O)OCC1c2ccccc2-c2ccccc21)C(=O)O)NC(=O)OC(C)(C)C</smiles>

Following GP1 with $D$-ornithine hydrochloride $(8.9 \mathrm{mmol})$ yielded II (3000 mg, $81 \%)$ as colorless foam.

Analytical data in accordance with reported in 2.1.1.

\subsection{General procedure for the methyl ester formation (GP2)}<smiles></smiles>

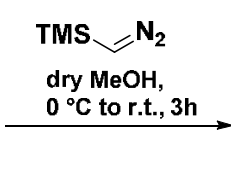<smiles></smiles>

Methyl esters are formed by treatment of the respective acids with diazomethane. ${ }^{3}$ Protected amino acid (1.0 eq) was solubilized in dry $\mathrm{MeOH}(7.7 \mathrm{~mL}$ per $1.0 \mathrm{mmol})$ and cooled to $0{ }^{\circ} \mathrm{C}$. TMSdiazomethane ( $2 \mathrm{M}$ solution in hexane, 5.0 eq.) was added dropwise to the reaction mixture under inert atmosphere and warmed to room temperature. The reaction was monitored every $30 \mathrm{~min}$ by TLC (cyclohexane/EtOAc, 7:3) with $p$-anisaldehyde as the visualizing agent. TMS-diazomethane (2.5 eq.) was added every 30 min until full conversion of the acid was observed. The reaction was then concentrated in vacuo to give the crude product which was purified by flash chromatography on silica gel (mobile phase: cyclohexane/EtOAc, 9:1 to 1:1). 


\subsubsection{Synthesis of Fmoc-L-Arg( $\left(,, \omega^{\prime}-B o c\right)-O M e(I I I)$}

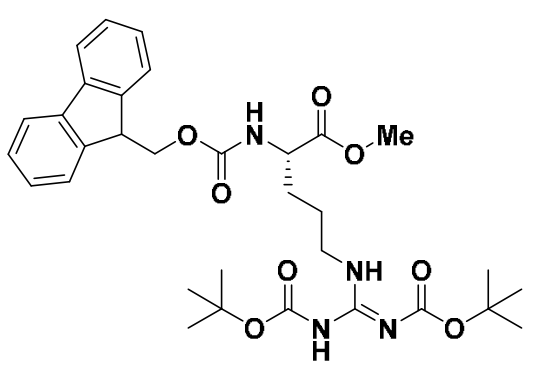

Following GP2 with compound I (1.20 mmol) yielded III (580 mg, $79 \%)$ as a white solid.

${ }^{1} \mathrm{H}-\mathrm{NMR}\left(500 \mathrm{MHz}, \mathrm{CDCl}_{3}\right): \delta=11.49\left(\mathrm{~s}, 1 \mathrm{H}, \mathrm{N} \underline{\mathrm{HCO}}{ }_{2} \mathrm{tBu}\right), 8.34(\mathrm{~s}$, $1 \mathrm{H}, \mathrm{N} \underline{\mathrm{H}}(1)), 7.76(\mathrm{~d}, J=7.6 \mathrm{~Hz}, 2 \mathrm{H}, 14-\mathrm{H}), 7.61(\mathrm{~m}, 2 \mathrm{H}, 11-\mathrm{H})$, $7.40(\mathrm{t}, J=7.4 \mathrm{~Hz}, 2 \mathrm{H}, 13-\mathrm{H}), 7.31(\mathrm{t}, J=7.4 \mathrm{~Hz}, 2 \mathrm{H}, 12-\mathrm{H}), 5.60$ $(\mathrm{d}, J=8.0 \mathrm{~Hz}, 1 \mathrm{H}, \mathrm{N} \underline{\mathrm{H}}(2)), 4.44-4.38(\mathrm{~m}, 3 \mathrm{H}, 2-\mathrm{H}, 8-\mathrm{H}), 4.23(\mathrm{t}, J$

$=7.1 \mathrm{~Hz}, 1 \mathrm{H}, 9-\mathrm{H}), 3.76\left(\mathrm{~s}, 3 \mathrm{H}, \mathrm{OC}_{\mathrm{H}_{3}}\right), 3.50-3.46\left(\mathrm{~m}, 1 \mathrm{H}, 5-\mathrm{H}_{\mathrm{A}}\right)$, $3.42-3.39\left(\mathrm{~m}, 1 \mathrm{H}, 5-\mathrm{H}_{\mathrm{B}}\right), 1.93-1.89\left(\mathrm{~m}, 1 \mathrm{H}, 3-\mathrm{H}_{\mathrm{A}}\right), 1.74-1.72\left(\mathrm{~m}, 1 \mathrm{H}, 3-\mathrm{H}_{\mathrm{B}}\right), 1.67-1.57(\mathrm{~m}, 2 \mathrm{H}, 4-$ $\mathrm{H}), 1.50\left(\mathrm{~s}, 18 \mathrm{H}, \mathrm{NHCO}_{2} \underline{\mathrm{tBu}}\right) \mathrm{ppm}$.

${ }^{13} \mathrm{C}-\mathrm{NMR}\left(125 \mathrm{MHz}, \mathrm{CDCl}_{3}\right.$ ): $\delta=$ 172.7, 163.6 (2s, C-1, C-6), 156.3 (s, $\underline{\mathrm{CO}}_{2} \mathrm{tBu}$ ), 156.0 (s, C-7), 153.4 (s, $\left.\mathrm{CO}_{2} t \mathrm{Bu}\right), 144.0^{*}, 143.8,141.4$ (2s, C-10, C-15), 127.7, 127.1, 125.2, 120.0 (4d, C-13, C-12, C-11, C-14), 83.3, $79.4\left(2 \mathrm{~s}, \mathrm{NHCO}_{2} \underline{\mathrm{tBu}}\right.$ ), 70.0 (t, C-8), 53.8 (d, C-2), 52.5 (q, $\left.\mathrm{OCH}_{3}\right), 47.3$ (d, C-9), 40.3, 29.5 (2t, C-5, $\mathrm{C}-3), 28.3,28.1\left(2 \mathrm{q}, \mathrm{NHCO}_{2} \underline{\mathrm{tBu}}\right), 25.4(\mathrm{t}, \mathrm{C}-4) \mathrm{ppm} *$ minor rotamers.

HRMS (ESI-TOF): calculated for $\mathrm{C}_{32} \mathrm{H}_{43} \mathrm{O}_{8} \mathrm{~N}_{4}[\mathrm{M}+\mathrm{H}]^{+} 611.3075$; found 611.3075 .

\subsubsection{Synthesis of Fmoc-D-Arg(,$\left.\infty^{\prime}-B o c\right)-O M e(I V)$}

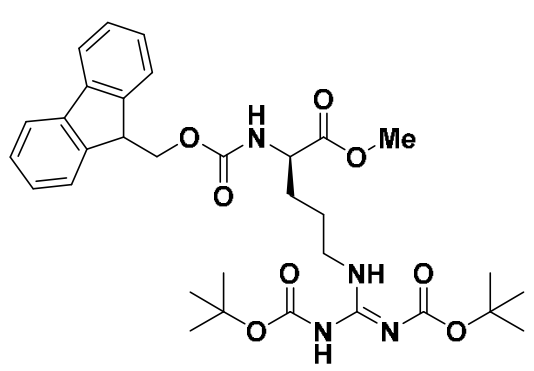

Following GP2 with compound II (1.20 mmol) yielded IV (555 $\mathrm{mg}, 76 \%)$ as a white solid.

Analytical data in accordance with reported in 2.2.1.

\subsubsection{Synthesis of Fmoc-L-Lys( $\varepsilon$-Boc)-OMe (V)}

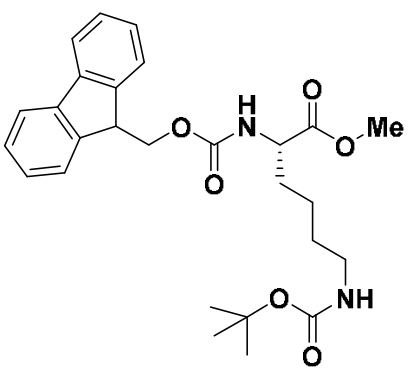

Following GP2 with Fmoc-L-Lys(Boc)-OH $(0.64 \mathrm{mmol})$ yielded V (268 $\mathrm{mg}, 87 \%)$ as a white solid.

${ }^{1} \mathrm{H}-\mathrm{NMR}\left(500 \mathrm{MHz}, \mathrm{CDCl}_{3}\right): \delta=7.76(\mathrm{~d}, J=7.7 \mathrm{~Hz}, 2 \mathrm{H}, 14-\mathrm{H}), 7.61(\mathrm{~m}, 2 \mathrm{H}$, $11-\mathrm{H}), 7.40(\mathrm{t}, J=7.7 \mathrm{~Hz}, 2 \mathrm{H}, 13-\mathrm{H}), 7.32(\mathrm{t}, J=7.7 \mathrm{~Hz}, 2 \mathrm{H}, 12-\mathrm{H}), 5.38(\mathrm{~d}$, $J=6.7 \mathrm{~Hz}, 1 \mathrm{H}, \mathrm{N} \underline{\mathrm{H}}(1)), 4.57$ (br. s, $\left.1 \mathrm{H}, \mathrm{C}-6, \mathrm{~N} \underline{\mathrm{H}} \mathrm{CO}_{2} t \mathrm{Bu}\right), 4.44-4.34(\mathrm{~m}, 3 \mathrm{H}$, $\left.2-\mathrm{H}, 8-\mathrm{H}), 4.23(\mathrm{t}, J=6.7 \mathrm{~Hz}, 1 \mathrm{H}, 9-\mathrm{H}), 3.75\left(\mathrm{~s}, 3 \mathrm{H}, \mathrm{OC}_{3}\right)_{3}\right), 3.12(\mathrm{~m}, 2 \mathrm{H}, 5-$ $\mathrm{H}), 1.90-1.83\left(\mathrm{~m}, 1 \mathrm{H}, 3-\mathrm{H}_{\mathrm{A}}\right), 1.74-1.67\left(\mathrm{~m}, 1 \mathrm{H}, 3-\mathrm{H}_{\mathrm{B}}\right), 1.52-1.49(\mathrm{~m}$, $2 \mathrm{H}, 5-\mathrm{H}), 1.45\left(\mathrm{~s}, 9 \mathrm{H}, \mathrm{NHCO}_{2} \underline{\mathrm{tBu}}\right), 1.40-1.31(\mathrm{~m}, 2 \mathrm{H}, 4-\mathrm{H}) \mathrm{ppm}$.

${ }^{13} \mathrm{C}-\mathrm{NMR}\left(125 \mathrm{MHz}, \mathrm{CDCl}_{3}\right): \delta=173.1$ (s, C-1), 156.2 (s, $\left.\mathrm{CO}_{2} t \mathrm{Bu}\right), 156.1$ (s, C-7), 144.1*, 143.9 (s, C-10), 141.5 (2s, C-10), 127.9, 127.2, 125.2 (3d, C-13, C-12, C-11), 120.1*, 120.1 (d, C-14), 79.4 (s, $\left.\mathrm{NHCO}_{2} \underline{\mathrm{tBu}}\right), 67.2(\mathrm{t}, \mathrm{C}-8), 53.8(\mathrm{~d}, \mathrm{C}-2), 52.6\left(\mathrm{q}, \mathrm{OCH}_{3}\right), 47.3$ (d, C-9), 40.2, 32.3, 29.8 (3t, C-6, C-3, C-5), 28.6 ( $\left.q, \mathrm{NHCO}_{2} \underline{\mathrm{tBu}}\right), 26.2$ (t, C-4) ppm (*minor rotamers).

HRMS (ESI-TOF): calculated for $\mathrm{C}_{27} \mathrm{H}_{35} \mathrm{O}_{6} \mathrm{~N}_{2}[\mathrm{M}+\mathrm{H}]^{+} 483.2490$; found 483.2494 . 


\subsubsection{Synthesis of Fmoc-D-Lys( $\varepsilon$-Boc)-OMe (VI)}

Following GP2 with Fmoc-D-Lys(Boc)-OH $(1.28 \mathrm{mmol})$ yielded VI (450<smiles>COC(=O)C(CCCCNC(=O)OC(C)(C)C)NC(=O)OCC1c2ccccc2-c2ccccc21</smiles>

$\mathrm{mg}, 73 \%)$ as a white solid.

Analytical data in accordance with reported in 2.2.3.

\subsection{General procedure for the reduction of methyl esters ${ }^{4}$ (GP3)}<smiles>[R]C[C@H](NC(=O)OCC1c2ccccc2-c2ccccc21)C(=O)OC</smiles>

DIBAL(H), DCM, $-78^{\circ} \mathrm{C}, 3 \mathrm{~h}$<smiles>[R]C[C@@H](C=O)NC(=O)OCC1c2ccccc2-c2ccccc21</smiles>

The obtained methyl ester (1.0 eq) was dissolved in DCM $(20 \mathrm{~mL}$ per $1.0 \mathrm{mmol})$ and cooled to $-78^{\circ} \mathrm{C}$ under argon flow. DIBAL(H) (1.2 $\mathrm{M}$ in toluene, 2.0 eq.) was added dropwise over $1 \mathrm{~h}$ and the reaction mixture was stirred at $-80^{\circ} \mathrm{C}$ for an additional hour. Reaction control was performed using TLC (cyclohexane/EtOAc, 7:3). In case reduction was incomplete after one hour, additional 0.5 eq. DIBAL(H) was added every 30 min until full conversion of the methyl ester to the aldehyde was observed. The solution was then quenched with a saturated solution of sodium potassium $L(+)-$ tartrate tetrahydrate $(30 \mathrm{~mL})$ until the production of gas ceased. DCM and saturated solution of Rochelle salt were then added in a ratio 1:1 in order to get an emulsion, which was strongly stirred for an additional hour. The water phase was three times extracted with DCM (3 $\times 40 \mathrm{~mL})$. Organic layers were combined, washed with brine, dried over $\mathrm{Na}_{2} \mathrm{SO}_{4}$, filtered and concentrated in vacuo to obtain respective aldehyde.

\subsubsection{Synthesis of Fmoc-L-Arg( $\left.\odot, \Phi^{\prime}-B o c\right)$ aldehyde (VII)}

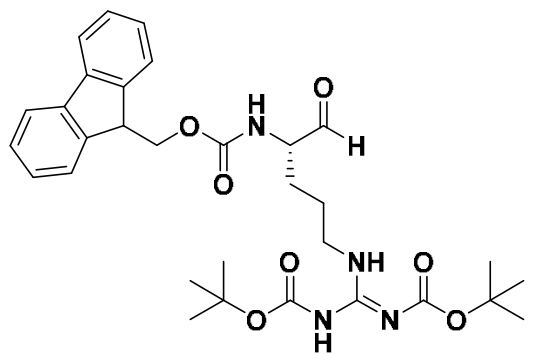

Following GP3 with III $(0.98 \mathrm{mmol})$ yielded VII $(550 \mathrm{mg})$ as a yellowish oil. The crude product was introduced into the next step without further purification due to the low stability of aldehydes. 


\subsubsection{Synthesis of Fmoc-D-Arg( $\left.\odot, \square^{\prime}-B o c\right)$ aldehyde (VIII)}

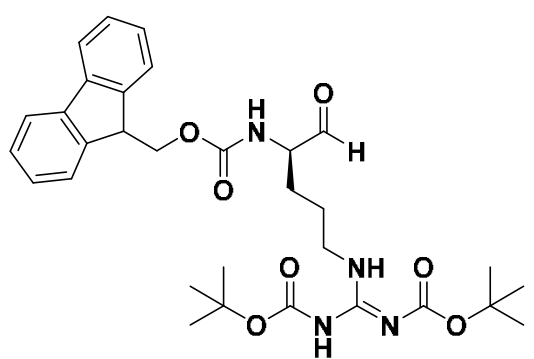

Following GP3 with IV (0.91 mmol) yielded VIII $(520 \mathrm{mg})$ as a yellowish oil. The crude product was introduced into the next step without further purification due to the low stability of aldehydes.

\subsubsection{Synthesis of Fmoc-L-Lys( $\varepsilon$-Boc) aldehyde (IX)}<smiles>CC(C)(C)OC(=O)NCCCC[C@@H](C=O)NC(=O)OCC1c2ccccc2-c2ccccc21</smiles>

Following GP3 with V $(0.36 \mathrm{mmol})$ yielded IX $(126 \mathrm{mg})$ as a yellowish oil. The crude product was introduced into the next step without further purification due to the low stability of aldehydes.

\subsubsection{Synthesis of Fmoc-D-Lys( $\varepsilon$-Boc) aldehyde (X)}<smiles>CC(C)(C)OC(=O)NCCCCC(C=O)NC(=O)OCC1c2ccccc2-c2ccccc21</smiles>

Following GP3 with VI $(0.98 \mathrm{mmol})$ yielded $\mathbf{X}(496 \mathrm{mg})$ as a yellowish oil. The crude product was introduced into the next step without further purification due to the low stability of aldehydes. 


\section{General procedure for solid-phase peptide synthesis (GP4)}

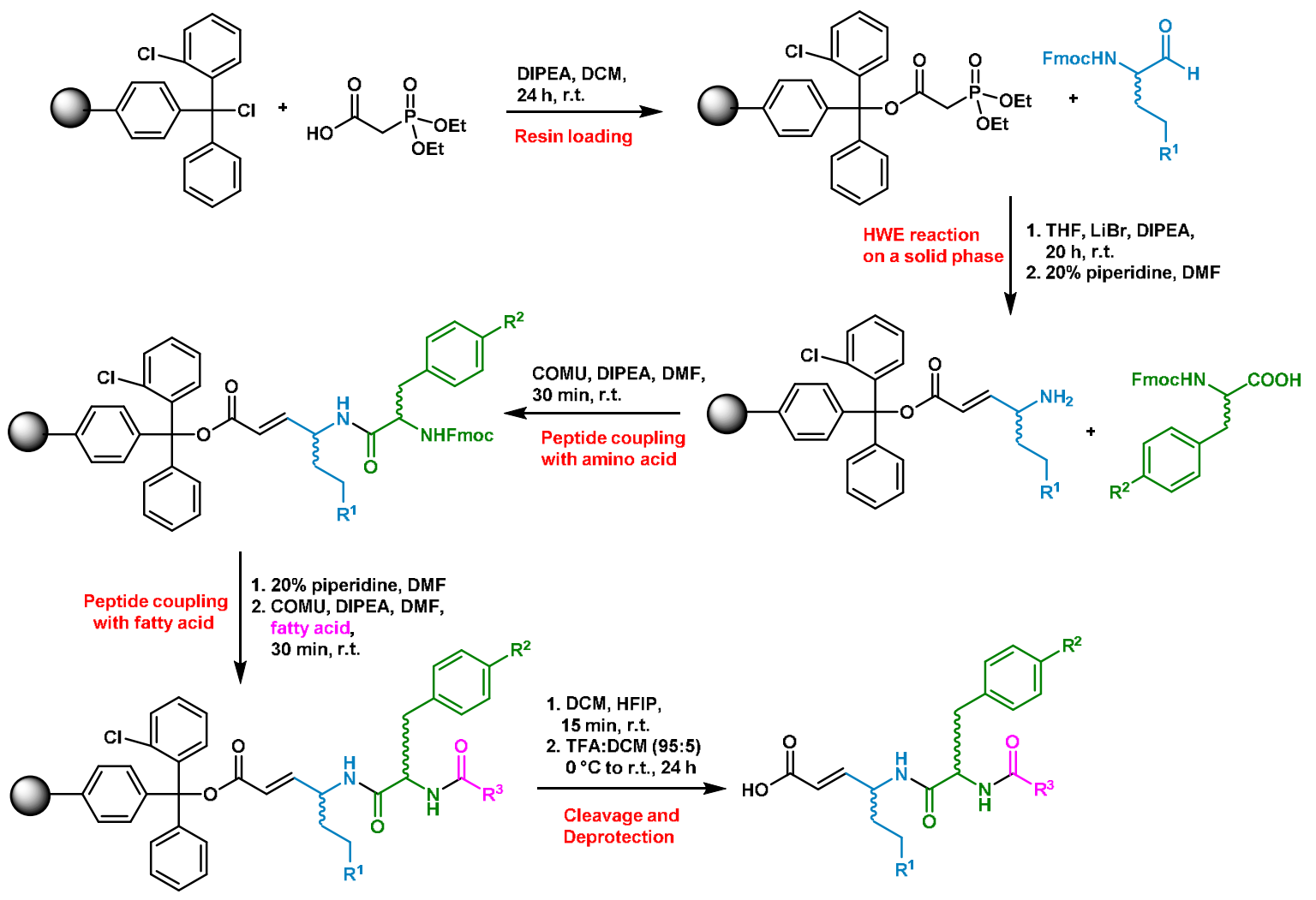

\section{Step 1: Loading of the resin}

2-Chlorotrityl chloride resin (CTC resin) (1 g) was suspended in DCM (15 mL) and allowed to swell for $1 \mathrm{~h}$. Meanwhile, diethylphosphonoacetic acid $(2.2 \mathrm{mmol}, 429 \mathrm{mg})$ was solubilized in DCM $(2-3 \mathrm{~mL})$ in a reaction vessel. Solubilized acid and DIPEA $(1.75 \mathrm{mmol}, 0.305 \mathrm{~mL})$ were added on the resin. After $5 \mathrm{~min}$ DIPEA ( $2.63 \mathrm{mmol}, 0.458 \mathrm{~mL}$ ) was added on the resin. Resin was shaken for $20 \mathrm{hrs}$. After 20 hrs, MeOH (1 mL per $1 \mathrm{~g}$ of resin) was added to quench the reaction and the resin was shaken for additional $30 \mathrm{~min}$. Subsequently, solvents were removed and the resin was alternatively three times washed with DCM ( $3 \times 10 \mathrm{~mL}$ per $1 \mathrm{~g}$ of resin) and THF ( $3 \times 10 \mathrm{~mL}$ per $1 \mathrm{~g}$ of resin), followed by a last wash with DCM (10 mL per $1 \mathrm{~g}$ of resin). Loaded resin was dried under vacuum and stored at $4{ }^{\circ} \mathrm{C}$ or below.

\section{Determination of phosphonate loading:}

A $2 \mathrm{ml}$ Eppendorf tube was charged with loaded resin $(\sim 100 \mathrm{mg})$. Then $\mathrm{CDCl}_{2}(0.8 \mathrm{~mL})$ was added followed by HFIP $(0.2 \mathrm{~mL})$. The Eppendorf tube was shaken at room temperature for $15 \mathrm{~min}$ and the resulting dark red suspension was passed through a syringe filter (PVDF, $0.45 \mu \mathrm{m}$ ). An aliquot of the clear solution $\left(0.6 \mathrm{~mL}\right.$ ) was added to the NMR tube already containing $\mathrm{PPh}_{3}$. The NMR tube was vortexed gently to achieve a homogenous solution. A non-decoupled ${ }^{31} \mathrm{P}-\mathrm{NMR}$ was measured with 128 scans. The $\mathrm{PPh}_{3}$ signal (-6.0 ppm, see figure) was set to have an integral of 1.00 . The loading was calculated using following formula and assuming a quantitative cleavage from the resin:

$$
\text { Loading in } \mathrm{mmol} / \mathrm{g}=\frac{x}{M W_{P P h_{3}}} \cdot y \cdot \frac{10}{6} \cdot \frac{1000}{z}
$$


$\mathrm{x}=$ amount of $\mathrm{PPh}_{3}$ (in $\mathrm{mg}$ ) in the NMR tube

$y={ }^{31} \mathrm{P}-\mathrm{NMR}$ integral of diethylphosphonoacetic acid (relative to $\mathrm{PPh}_{3}=1$ )

$\mathrm{z}=$ amount of loaded resin (in $\mathrm{mg}$ ) in the Eppendorf tube

$\mathrm{MW}_{\mathrm{PPh} 3}=262.29 \mathrm{~g} / \mathrm{mol}$

This procedure was repeated three times and the average was calculated as the loading of the resin. The loading of the resin was determined to be $\mathbf{0 . 8} \mathbf{~ m m o l} / \mathrm{g}$.

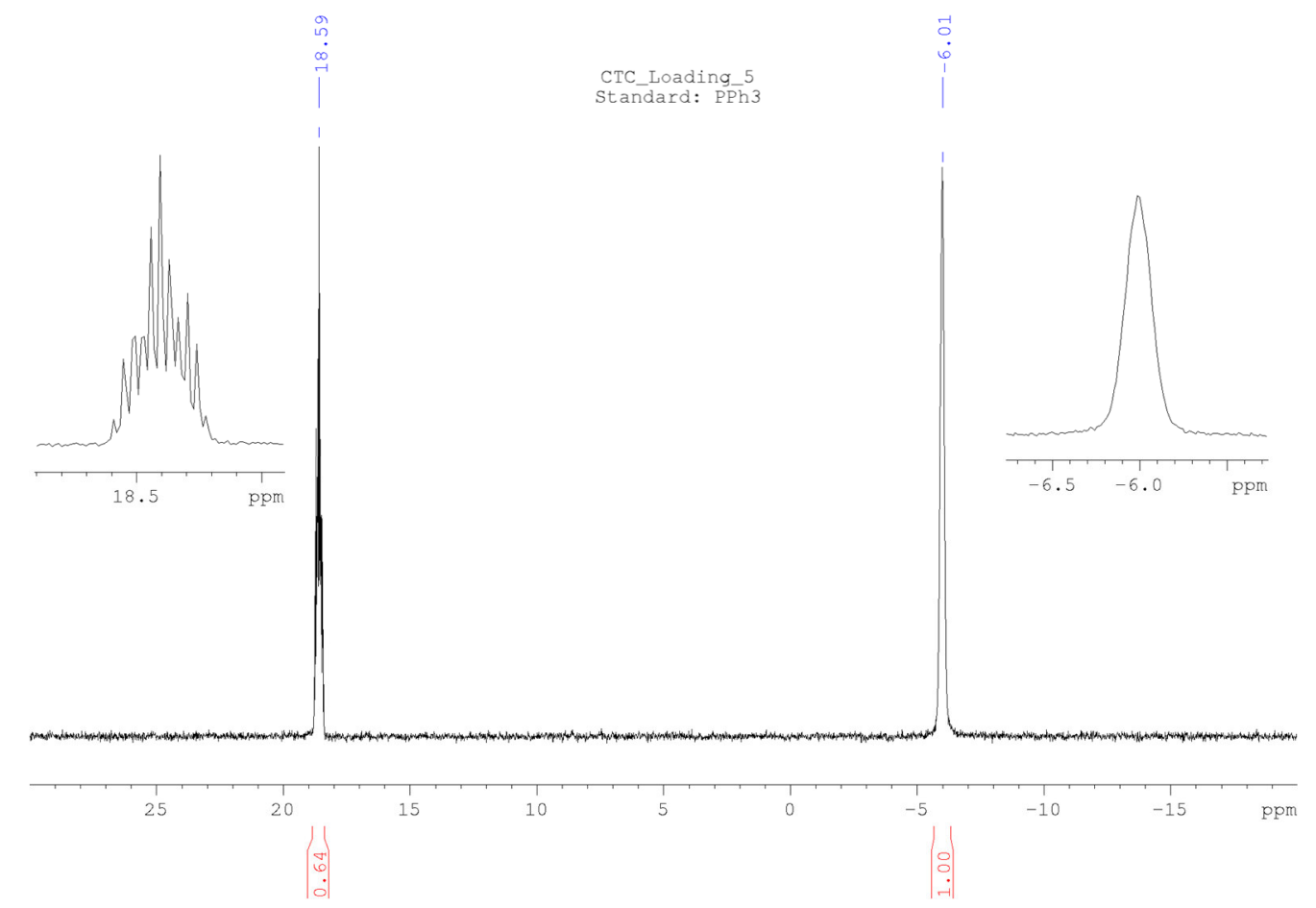

Typical ${ }^{31} \mathrm{P}-\mathrm{NMR}$ spectra of the loading determination protocol.

\section{Step 2: HWE reaction}

The protocol of HWE reaction on a solid-phase was adapted from Johnson et. al ${ }^{5}$ and Sun et. $a l^{6}$. Loaded CTC resin $(1 \mathrm{~g})$ was swollen in THF $(10-15 \mathrm{~mL})$ for $1 \mathrm{~h}$. Meanwhile, LiBr $(1.0 \mathrm{mmol}, 87 \mathrm{mg})$ and DIPEA $(0.75 \mathrm{mmol}, 0.137 \mathrm{~mL})$ were solubilized in THF $(2-3 \mathrm{~mL})$ and added to the resin. Vinylogous arginine aldehyde $(1.5 \mathrm{mmol}, 679 \mathrm{mg})$ was dissolved in THF $(2-3 \mathrm{~mL})$ and added to the resin. The resin was shaken for $20 \mathrm{hrs}$ at ambient temperature. The reaction was monitored through the Kaiser test ${ }^{1}$. After $20 \mathrm{hrs}$, solvents were removed and the resin was alternatively three times washed with THF ( $3 \times 10 \mathrm{~mL}$ per $1 \mathrm{~g}$ of resin) and $\mathrm{MeOH}(3 \times 10 \mathrm{~mL}$ per $1 \mathrm{~g}$ of resin), followed by a last wash with DMF (10 mL per $1 \mathrm{~g}$ of resin). The intermediate was used without further purification in the next step.

\section{Step 3 and 5: Deprotection}

The resin was premixed with $20 \%$ piperidine and DMF and shaken 3 times for 5 min $(3 \times 5 \mathrm{~mL}$ per $1 \mathrm{~g}$ of resin). The resulting deprotected compound (on resin) was washed 3 times alternatively with DMF ( $3 \times 10 \mathrm{~mL}$ per $1 \mathrm{~g}$ of resin) and $\mathrm{MeOH}(3 \times 10 \mathrm{~mL}$ per $1 \mathrm{~g}$ of resin), followed by a final wash with DMF (10 $\mathrm{mL}$ per $1 \mathrm{~g}$ of resin). 


\section{Step 4: Coupling with Fmoc-protected amino acid}

The corresponding amino acid (1.5 mmol per $1 \mathrm{~g}$ of resin), e.g. Fmoc- $\operatorname{Tyr}(t \mathrm{Bu})-\mathrm{OH}(1.5 \mathrm{mmol}, 689$ $\mathrm{mg})$, and COMU (1.25 mmol, $535 \mathrm{mg}$ ) were solubilized in DMF $(6 \mathrm{~mL})^{7}$. DIPEA ( $2.5 \mathrm{mmol}, 0.437 \mathrm{~mL}$ ) was added and the reaction mixture was added to the resin. The resin was shaken and after $30 \mathrm{~min}$ solvents were removed and the resin was alternatively 3-times washed with DMF $(3 \times 10 \mathrm{~mL}$ per $1 \mathrm{~g}$ of resin) and $\mathrm{MeOH}(3 \times 10 \mathrm{~mL}$ per $1 \mathrm{~g}$ of resin), followed by a last wash with DMF (10 mL per $1 \mathrm{~g}$ of resin). The coupling and washing were repeated. The reaction process was monitored through the Kaiser test. The resin-bound product was introduced into the next step without further purification.

\section{Step 6: Acylation}

The corresponding acid (1.5 mmol per $1 \mathrm{~g}$ of resin), e.g. 2-octenoic acid (1.5 mmol, $0.226 \mathrm{~mL})$, and COMU (1.25 mmol, $535 \mathrm{mg}$ ) were solubilized in DMF (10 mL per $1 \mathrm{~g}$ of resin). DIPEA ( $2.5 \mathrm{mmol}, 0.436$ $\mathrm{mL}$ ) was added and the reaction mixture was poured to the resin. The procedure for workup was analogous to step 4.

\section{Step 7: Cleavage from resin ${ }^{8}$}

The resin was solubilized in DCM ( $8 \mathrm{~mL}$ per $1 \mathrm{~g}$ of resin) and transferred into the round bottom flask. HFIP ( $2 \mathrm{~mL}$ per $1 \mathrm{~g}$ of resin) was added in a ration (HFIP:DCM; 1:4) and the suspension was shaken for $15 \mathrm{~min}$. After $15 \mathrm{~min}$, the resin was filtered and the reaction mixture was quickly concentrated in vacuo. The resulting product was introduced into the next step without further purification.

\section{Step 8: Deprotection}

Cleaved product was cooled to $0{ }^{\circ} \mathrm{C}$. Trifluoroacetic acid (TFA) in DCM (95:5) was added to the starting material ( $1 \mathrm{~mL}$ per $100-200 \mathrm{mg}$ of cleaved product). The reaction was warmed to r.t. and stirred overnight. Subsequently, the reaction was concentrated in vacuo and the crude product was purified by HPLC to obtain a pure lipodipeptide.

\section{General procedure for the esterification of the C-terminus (GP5)}

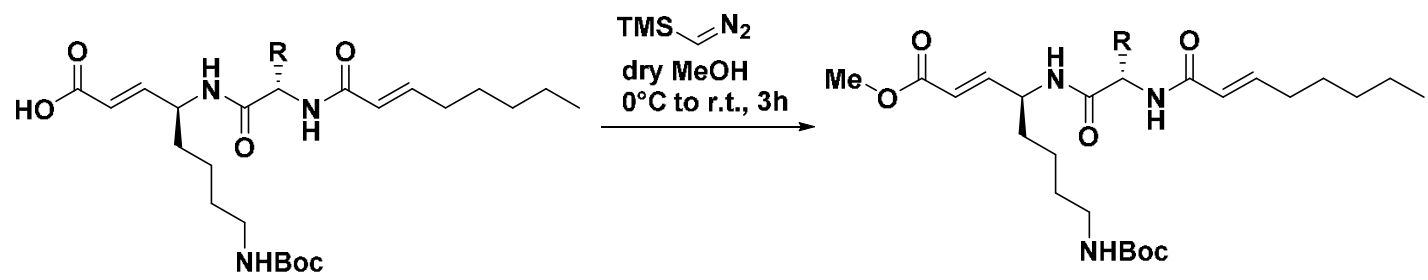

The protected lipodipeptide (1.0 eq) was solubilized in dry $\mathrm{MeOH}(7.7 \mathrm{~mL}$ per $1.0 \mathrm{mmol}$ ) and cooled to $0{ }^{\circ} \mathrm{C}$. TMS-diazomethane ( $2 \mathrm{M}$ solution in hexane, 5.0 eq.) was added dropwise to the reaction mixture under inert atmosphere and let warm to room temperature. The reaction was monitored by LC-MS. TMS-diazomethane ( 0.5 eq.) was added every 30 min until full conversion of the acid was observed. The reaction was then concentrated in vacuo to give the crude product which was purified by flash chromatography on reverse phase (mobile phase: $\mathrm{MeOH}: \mathrm{H}_{2} \mathrm{O}, 1: 9$ to 10:0). 


\section{Experimental Procedures of SPPS and Analytical Data}

\section{1 (S,E)-7-guanidino-4-((S)-3-(4-hydroxyphenyl)-2-((E)-oct-2-enamido)propanamido)hep-}

2-enoic acid (Barnesin A, 1)

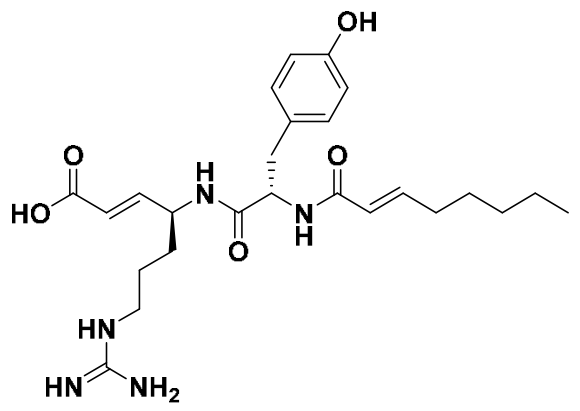

Following GP4 (Step 1 - Step 8) with VII $(0.34 \mathrm{mmol})$ and $688 \mathrm{mg}$ of loaded resin yielded 1 ( $2.8 \mathrm{mg}, 1.0 \%$ overall yield) as a white solid after purification on semipreparative HPLC.

${ }^{1} \mathrm{H}-\mathrm{NMR}$ (600 MHz, DMSO-d $\left.)_{6}\right): \delta=0.85(\mathrm{t}, J=6.7 \mathrm{~Hz}, 3 \mathrm{H}), 1.23$ $(\mathrm{m}, 2 \mathrm{H}), 1.27(\mathrm{~m}, 2 \mathrm{H}), 1.35(\mathrm{~m}, 2 \mathrm{H}), 1.45(\mathrm{~m}, 2 \mathrm{H}), 1.46(\mathrm{~m}, 1 \mathrm{H})$, $1.69(\mathrm{~m}, 1 \mathrm{H}), 2.08(\mathrm{~m}, 2 \mathrm{H}), 2.59(\mathrm{~m}, 1 \mathrm{H}), 2.87(\mathrm{~m}, 1 \mathrm{H}), 3.06(\mathrm{~m}$, $2 \mathrm{H}), 4.34(\mathrm{~m}, 2 \mathrm{H}), 4.47(\mathrm{~m}, 2 \mathrm{H}), 5.73(\mathrm{~d}, J=15.4 \mathrm{~Hz}, 1 \mathrm{H}), 5.90$ $(\mathrm{d}, J=15.3 \mathrm{~Hz}, 1 \mathrm{H}), 6.46(\mathrm{dd}, J=15.7,4.8 \mathrm{~Hz}, 1 \mathrm{H}), 6.50(\mathrm{dt}, J=$ $15.4,6.8 \mathrm{~Hz}, 1 \mathrm{H}), 6.60(\mathrm{~d}, J=8.2 \mathrm{~Hz}, 2 \mathrm{H}), 7.00(\mathrm{~d}, J=8.3 \mathrm{~Hz}, 2 \mathrm{H}), 8.05(\mathrm{~d}, J=8.5 \mathrm{~Hz}, \mathrm{NH}), 8.46(\mathrm{~d}, J=$ $7.9 \mathrm{~Hz}, \mathrm{~N} \underline{\mathrm{H}}), 9.80$ (br., N트) ppm.

${ }^{13}$ C-NMR (150 MHz, DMSO-d $\left.d_{6}\right): \delta=13.9,21.9,24.9,27.5,30.7,30.8,31.1,37.3,40.4,48.9,54.6$, $114.8,124.3,124.7,128.0,129.9,142.6,144.3,155.7,157.4,164.7,169.7,171.1$ ppm.

HRMS (ESI-TOF): calculated for $\mathrm{C}_{25} \mathrm{H}_{38} \mathrm{~N}_{5} \mathrm{O}_{5}[\mathrm{M}+\mathrm{H}]^{+} 488.2868$; found 488.2869 .

IR (ATR) $v_{\text {max }}: 1113,1417,1652,1716,1732,2835,2921,2947,3309 \mathrm{~cm}^{-1}$.

$[\alpha]_{D}^{25}:-1.95^{\circ}$ (c 1.0; MeOH).

\section{2 (R,E)-7-guanidino-4-((S)-3-(4-hydroxyphenyl)-2-((E)-oct-2-}

\section{enamido)propanamido)hept-2-enoic acid (Barnesin-D-Arginine-L-Tyrosine, 5)}

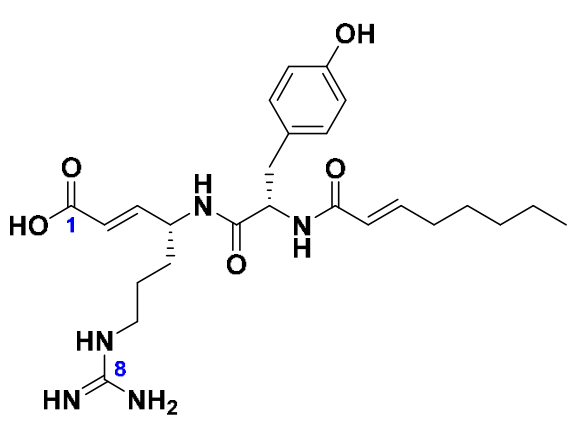

Following GP4 (Step 1 - Step 8) with VIII $(0.96 \mathrm{mmol})$ and $637 \mathrm{mg}$ of loaded resin yielded $\mathbf{5}$ ( $1.95 \mathrm{mg}, 0.8 \%$ overall yield) as a white solid after purification on semipreparative HPLC.

${ }^{1} \mathrm{H}-\mathrm{NMR}\left(600 \mathrm{MHz}\right.$, DMSO- $\left.d_{6}\right): \delta=0.85(\mathrm{t}, J=6.9 \mathrm{~Hz}, 3 \mathrm{H}), 1.23$ $(\mathrm{m}, 2 \mathrm{H}), 1.26(\mathrm{~m}, 2 \mathrm{H}), 1.29(\mathrm{~m}, 2 \mathrm{H}), 1.35(\mathrm{~m}, 2 \mathrm{H}), 1.45(\mathrm{~m}, 1 \mathrm{H})$, $1.58(\mathrm{~m}, 1 \mathrm{H}), 2.07(\mathrm{~m}, 2 \mathrm{H}), 2.66(\mathrm{~m}, 1 \mathrm{H}), 2.82(\mathrm{~m}, 1 \mathrm{H}), 2.97(\mathrm{~m}$, $2 \mathrm{H}), 4.29(\mathrm{~m}, 2 \mathrm{H}), 4.52(\mathrm{~m}, 2 \mathrm{H}), 5.70(\mathrm{~d}, J=15.5 \mathrm{~Hz}, 1 \mathrm{H}), 5.93$ $(\mathrm{d}, J=15.5 \mathrm{~Hz}, 1 \mathrm{H}), 6.37(\mathrm{dd}, J=15.9,5.3 \mathrm{~Hz}, 1 \mathrm{H}), 6.50(\mathrm{dt}, J=$ 15.1, 7.1 Hz, 1H), $6.60(\mathrm{~d}, J=8.4 \mathrm{~Hz}, 2 \mathrm{H}), 7.00(\mathrm{~d}, J=8.4 \mathrm{~Hz}, 2 \mathrm{H}), 8.15(\mathrm{~d}, J=8.3 \mathrm{~Hz}, \mathrm{~N} \underline{\mathrm{H}}), 8.21(\mathrm{~d}, J=$ $8.3 \mathrm{~Hz}, \mathrm{~N} \underline{\mathrm{H}}), 10.02$ (br., N트) ppm.

${ }^{13}$ C-NMR (150 MHz, DMSO- $d_{6}$ ): $\delta=13.9,21.9,22.1,27.5,30.8,30.9,31.2,37.5,40.4,48.7,54.6$, $114.9,124.4,128.0,128.7,130.0,141.2,142.7,155.9,164.6,170.8$ ppm.

Note: Two quarternary carbons $(\mathrm{C} 1, \mathrm{C} 8)$ are not detectable in the carbon spectra.

HRMS (ESI-TOF): calculated for $\mathrm{C}_{25} \mathrm{H}_{38} \mathrm{~N}_{5} \mathrm{O}_{5}[\mathrm{M}+\mathrm{H}]^{+} 488.2868$; found 488.2855 .

IR (ATR) V $v_{\text {max }}: 797,1190,1249,1399,1657,1745,1872,2913,2954,3304,0,83366 \mathrm{~cm}^{-1}$.

$[\alpha]_{D}^{25}:-0.33(c 1.0 ; \mathrm{MeOH})$. 


\section{$5.3(S, E)-7-g u a n i d i n o-4-((R)-3-(4-h y d r o x y p h e n y l)-2-((E)-o c t-2-$}

\section{enamido)propanamido)hept-2-enoic acid (Barnesin-L-Arginine-D-Tyrosine, 6 )}

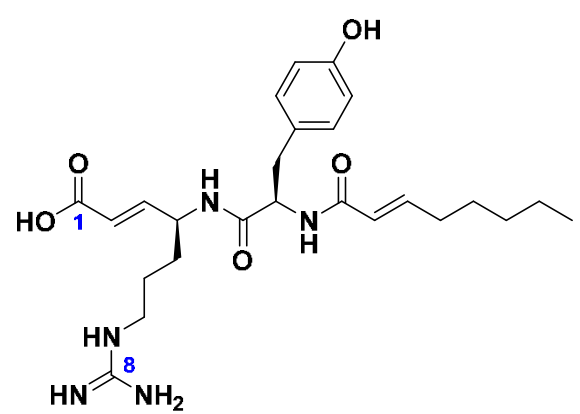

Following GP4 (Step 1 - Step 8) with VII $(0.42 \mathrm{mmol})$ and $280 \mathrm{mg}$ of loaded resin, followed by a peptide coupling with Fmoc-D-Tyr(tBu)-OH in step 4 of GP4, yielded 13 (2.15 mg, 2 $\%$ overall yield) as a white solid after purification on semipreparative HPLC.

${ }^{1} \mathrm{H}-\mathrm{NMR}$ (600 MHz, DMSO-d $)^{\text {): } \delta}=0.85(\mathrm{t}, \mathrm{J}=6.7 \mathrm{~Hz}, 3 \mathrm{H}$ ), 1.23 $(\mathrm{m}, 2 \mathrm{H}), 1.24(\mathrm{~m}, 2 \mathrm{H}), 1.29(\mathrm{~m}, 2 \mathrm{H}), 1.35(\mathrm{~m}, 2 \mathrm{H}), 1.45(\mathrm{~m}, 1 \mathrm{H})$, $1.58(\mathrm{~m}, 1 \mathrm{H}), 2.07(\mathrm{~m}, 2 \mathrm{H}), 2.66(\mathrm{~m}, 1 \mathrm{H}), 2.82(\mathrm{~m}, 1 \mathrm{H}), 2.97$ $(\mathrm{m}, 2 \mathrm{H}), 4.28(\mathrm{~m}, 2 \mathrm{H}), 4.52(\mathrm{~m}, 2 \mathrm{H}), 5.70(\mathrm{~d}, J=15.8 \mathrm{~Hz}, 1 \mathrm{H}), 5.94(\mathrm{~d}, J=15.8 \mathrm{~Hz}, 1 \mathrm{H}), 6.36(\mathrm{dd}, J=$ $15.8,5.2 \mathrm{~Hz}, 1 \mathrm{H}$ ), $6.53(\mathrm{dt}, J=15.0,7.2 \mathrm{~Hz}, 1 \mathrm{H}), 6.60(\mathrm{~d}, J=8.5 \mathrm{~Hz}, 2 \mathrm{H}), 6.99(\mathrm{~d}, J=8.3 \mathrm{~Hz}, 2 \mathrm{H}), 8.15(\mathrm{~d}$, $J=8.1 \mathrm{~Hz}, \mathrm{~N} \underline{\mathrm{H}}), 8.21$ (d, $J=8.1 \mathrm{~Hz}, \mathrm{~N} \underline{\mathrm{H}}), 9.99$ (br., N트) ppm.

${ }^{13}$ C-NMR (150 MHz, DMSO-d $d_{\text {): }} \delta=14.3,22.3,22.5,27.9,29.1,31.3,31.6,38.0,40.4,49.2,55.0$, $115.4,124.8,128.3,129.2,130.5,140.8,143.1,156.3,165.0,171.2 \mathrm{ppm}$.

Note: Two quarternary carbons $(\mathrm{C} 1, \mathrm{C} 8)$ were not detectable in the carbon spectra.

HRMS (ESI-TOF): calculated for $\mathrm{C}_{25} \mathrm{H}_{38} \mathrm{~N}_{5} \mathrm{O}_{5}[\mathrm{M}+\mathrm{H}]^{+} 488.2868$; found 488.2853 .

IR (ATR) V $V_{\text {max }}: 710,983,1122,1256,1351,1588,1864,2852,2921,3304 \mathrm{~cm}^{-1}$.

$[\alpha]_{D}^{25}:-7.93^{\circ}(c$ 1.0; $\mathrm{MeOH})$.

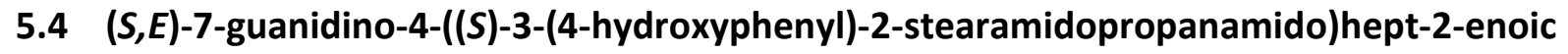
acid (Barnesin-L-Arginine-L-Tyrosine-stearic acid, 7)

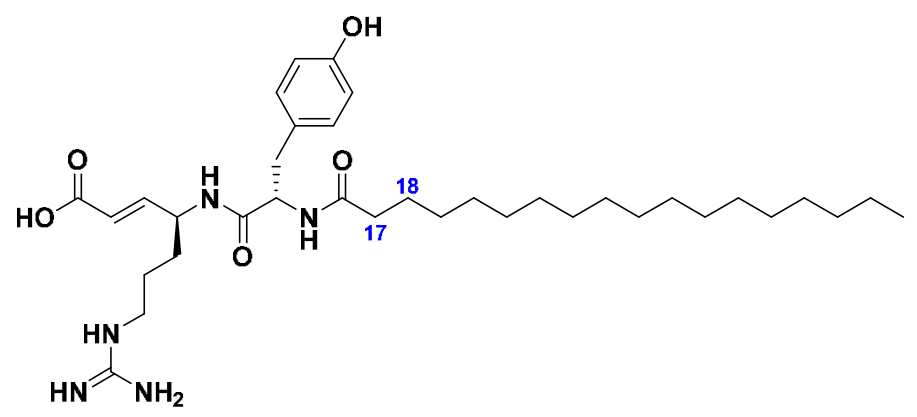

Following GP4 (Step 1 - Step 8) with VII $(0.75 \mathrm{mmol})$ and $500 \mathrm{mg}$ of loaded resin, followed by a coupling with stearic acid (0.75 mmol, 3.0 eq.) in step 6 of GP4, yielded 7 (14.0 mg, $5.6 \%$ overall yield) as a white solid after purification on semipreparative HPLC.

${ }^{1} \mathrm{H}-\mathrm{NMR}\left(600 \mathrm{MHz}\right.$, DMSO- $\left.d_{6}\right): \delta=0.85$ (t, J = 6.5 Hz, 3H), $1.08(\mathrm{~m}, 2 \mathrm{H}), 1.17(\mathrm{~m}, 4 \mathrm{H}), 1.23(\mathrm{~m}, 22 \mathrm{H}), 1.34(\mathrm{~m}, 2 \mathrm{H}), 1.44(\mathrm{~m}, 3 \mathrm{H}), 1.62(\mathrm{~m}, 1 \mathrm{H})$, $1.99(\mathrm{~m}, 2 \mathrm{H}), 2.61(\mathrm{~m}, 1 \mathrm{H}), 2.84(\mathrm{~m}, 1 \mathrm{H}), 3.05(\mathrm{~m}, 2 \mathrm{H}), 4.36(\mathrm{~m}, 1 \mathrm{H}), 4.40(\mathrm{~m}, 1 \mathrm{H}), 5.72(\mathrm{~d}, J=15.4 \mathrm{~Hz}$, $1 \mathrm{H}), 6.50(\mathrm{dd}, J=5.0,15.4 \mathrm{~Hz}, 1 \mathrm{H}), 6.60(\mathrm{~d}, J=8.3 \mathrm{~Hz}, 2 \mathrm{H}), 6.98(\mathrm{~d}, J=8.3 \mathrm{~Hz}, 2 \mathrm{H}), 7.91(\mathrm{~d}, J=8.3 \mathrm{~Hz}$,

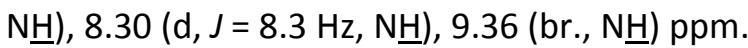

${ }^{13} \mathrm{C}-N M R\left(150 \mathrm{MHz}\right.$, DMSO- $\left.d_{6}\right): \delta=13.9,22.1,25.2,24.8,28.8\left(\mathrm{~m}, 12 \times \mathrm{CH}_{2}\right), 30.7,31.3,35.2,37.2$, $40.1,48.8,54.4,114.8,125.4,127.9,130.0,143.6,155.8,157.3,169.8,171.2,172.0$ ppm.

HRMS (ESI-TOF): calculated for $\mathrm{C}_{35} \mathrm{H}_{60} \mathrm{~N}_{5} \mathrm{O}_{5}[\mathrm{M}+\mathrm{H}]^{+} 630.4589$; found 630.4579 .

IR (ATR) $v_{\text {max }}: 1017,1205,1647,1710,3233,3379 \mathrm{~cm}^{-1}$ 
$[\alpha]_{\mathrm{D}}^{25}:+2.58^{\circ}(c 1.0 ; \mathrm{MeOH})$

5.5 (S,E)-7-guanidino-4-((S)-3-(4-hydroxyphenyl)-2-octanamidopropanamido)hept-2enoic acid (17,18-Dihydrobarnesin, 8)

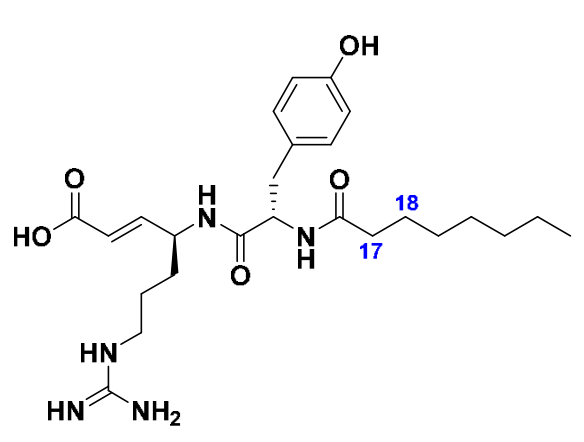

Following GP4 (Step 1 - Step 8) with VII $(3.00$ mmol) and $500 \mathrm{mg}$ of loaded resin, followed by a coupling with octanoic acid ( $0.75 \mathrm{mmol}, 3.0$ eq.) in step 6 of GP4, yielded $8(2.30 \mathrm{mg}$, $1.2 \%$ overall yield) as a white solid after purification on semipreparative HPLC.

${ }^{1} \mathrm{H}-\mathrm{NMR}(600 \mathrm{MHz} \text {, DMSO-d })^{\text {): } \delta}=0.85(\mathrm{t}, J=7.1 \mathrm{~Hz}, 3 \mathrm{H}), 1.08$ $(\mathrm{m}, 2 \mathrm{H}), 1.18(\mathrm{~m}, 4 \mathrm{H}), 1.24(\mathrm{~m}, 2 \mathrm{H}), 1.35(\mathrm{~m}, 2 \mathrm{H}), 1.38(\mathrm{~m}, 1 \mathrm{H})$, $1.45(\mathrm{~m}, 2 \mathrm{H}), 1.66(\mathrm{~m}, 1 \mathrm{H}), 1.99(\mathrm{~m}, 2 \mathrm{H}), 2.59(\mathrm{~m}, 1 \mathrm{H}), 2.85(\mathrm{~m}$, $1 \mathrm{H}), 3.05(\mathrm{~m}, 2 \mathrm{H}), 4.34(\mathrm{~m}, 1 \mathrm{H}), 4.42(\mathrm{~m}, 1 \mathrm{H}), 5.73(\mathrm{~d}, J=15.4 \mathrm{~Hz}, 1 \mathrm{H}), 6.43(\mathrm{dd}, J=15.4,4.9 \mathrm{~Hz}, 1 \mathrm{H})$, $6.61(\mathrm{~d}, J=8.4 \mathrm{~Hz}, 2 \mathrm{H}), 6.98(\mathrm{~d}, J=8.4 \mathrm{~Hz}, 2 \mathrm{H}), 7.92(\mathrm{~d}, J=8.7 \mathrm{~Hz}, \mathrm{NH}), 8.37(\mathrm{~d}, J=8.2 \mathrm{~Hz}, \mathrm{~N} \underline{\mathrm{H}}), 9.81$ (br., N $\underline{H}$ ) ppm.

${ }^{13} \mathrm{C}-N M R\left(150 \mathrm{MHz}\right.$, DMSO- $\left.d_{6}\right): \delta=14.4,22.7,25.2,25.8,29.1,29.1,31.2,31.7,35.9,37.8,40.5,49.3$, $54.9,115.4,127.9,128.7,130.6,142.5,156.2,158.0,171.4,171.6,172.6$ ppm.

HRMS (ESI-TOF): calculated for $\mathrm{C}_{25} \mathrm{H}_{40} \mathrm{~N}_{5} \mathrm{O}_{5}[\mathrm{M}+\mathrm{H}]^{+} 490.3024$; found 490.3008 .

IR (ATR) V $\max : 717,743,983,1056,1253,1354,1610,2710,2848,2925,3271,3304 \mathrm{~cm}^{-1}$.

$[\alpha]_{D}^{25}:+2.09^{\circ}(c 1.0 ; \mathrm{MeOH})$.

\section{$5.6(S, E)-4-((S)-2-((E)$-but-2-enamido)-3-(4-hydroxyphenyl)propanamido)-7-}

\section{guanidinohept-2-enoic acid (Barnesin-trans-2-butenoic acid, 9)}

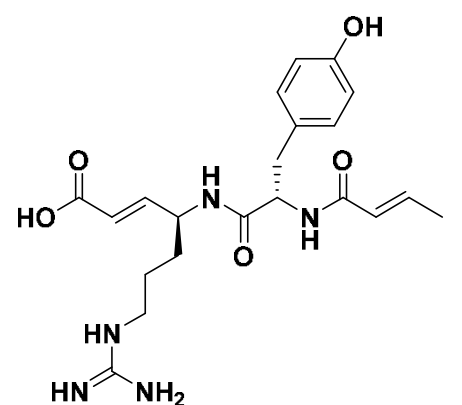

Following GP4 (Step 1 - Step 8) with VII $(1.17 \mathrm{mmol})$ and $778 \mathrm{mg}$ of loaded resin, followed by a coupling with trans-2-butenoic acid (3 eq.) in step 6 of GP4, yielded $\mathbf{9}(7.71 \mathrm{mg}, 2.9 \%$ overall yield) as a white solid after purification on semipreparative HPLC.

${ }^{1}$ H-NMR (600 MHz, DMSO- $\left.d_{6}\right): \delta=1.30(\mathrm{~m}, 1 \mathrm{H}), 1.31(\mathrm{~m}, 2 \mathrm{H}), 1.61(\mathrm{~m}$, $1 \mathrm{H}), 1.73(\mathrm{~d}, J=5.7 \mathrm{~Hz}, 3 \mathrm{H}), 2.66(\mathrm{~m}, 1 \mathrm{H}), 2.82(\mathrm{~m}, 1 \mathrm{H}), 2.98(\mathrm{~m}, 2 \mathrm{H})$, $4.29(\mathrm{~m}, 1 \mathrm{H}), 4.52(\mathrm{~m}, 1 \mathrm{H}), 5.70(\mathrm{~d}, J=15.5 \mathrm{~Hz}, 1 \mathrm{H}), 5.95(\mathrm{~d}, J=15.4$ $\mathrm{Hz}, 1 \mathrm{H}), 6.39(\mathrm{dd}, J=15.5,5.6 \mathrm{~Hz}, 1 \mathrm{H}), 6.52(\mathrm{dt}, J=15.1,6.8 \mathrm{~Hz}, 1 \mathrm{H}), 6.62(\mathrm{~d}, J=8.3 \mathrm{~Hz}, 2 \mathrm{H}), 7.00(\mathrm{~d}, J$ $=8.3 \mathrm{~Hz}, 2 \mathrm{H}), 8.12(\mathrm{~d}, J=9.0 \mathrm{~Hz}, \mathrm{~N} \underline{\mathrm{H}}), 8.19(\mathrm{~d}, J=8.4 \mathrm{~Hz}, \mathrm{NH}), 10.08(\mathrm{br}, \mathrm{NH}) \mathrm{ppm}$.

${ }^{13} \mathrm{C}$-NMR (150 MHz, DMSO- $\left.d_{6}\right): \delta=22.8,25.1,31.0,37.3,40.6,48.8,54.6,114.9,125.3,127.9,130.0$, $143.8,156.0,157.5,169.0,169.7,171.3 \mathrm{ppm}$.

HRMS (ESI-TOF): calculated for $\mathrm{C}_{21} \mathrm{H}_{30} \mathrm{~N}_{5} \mathrm{O}_{5}[\mathrm{M}+\mathrm{H}]^{+} 432.2242$; found 432.2243 .

IR (ATR) $\mathbf{V}_{\max }: 1101,1240,1390,1449,1637,2829,2944,3268,3345 \mathrm{~cm}^{-1}$.

$[\alpha]_{D}^{25}:-3.52^{\circ}(c 1.0 ; \mathrm{MeOH})$. 


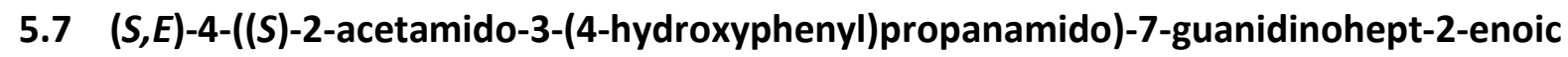
acid (Acylderivative, 10)

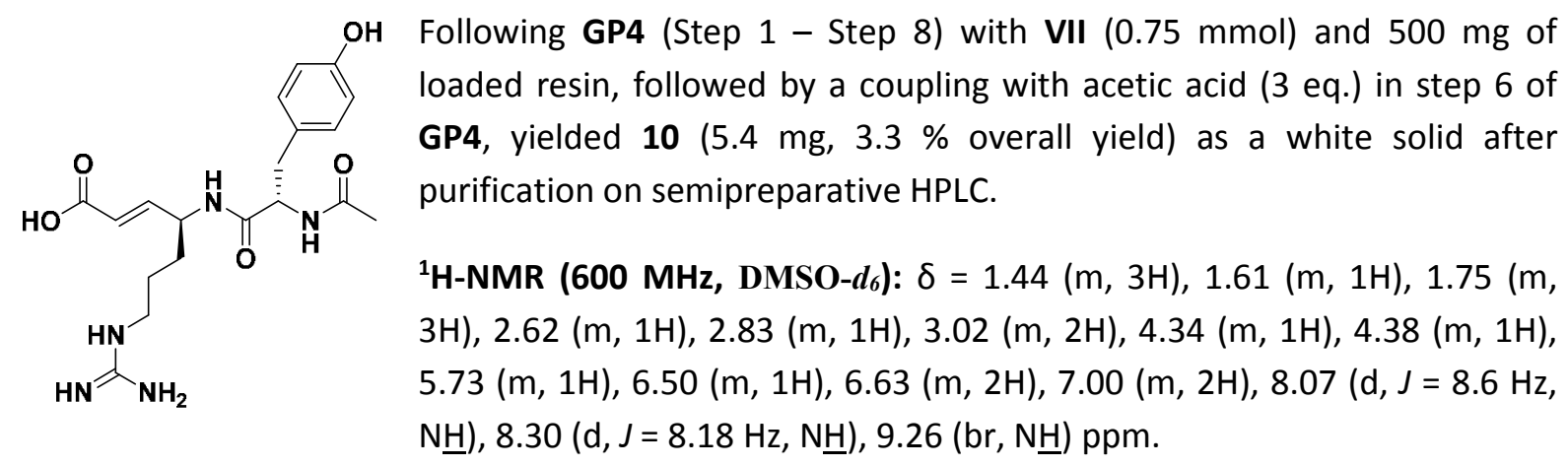

${ }^{13} \mathrm{C}$-NMR (150 MHz, DMSO-d $)$ : $\delta=22.8,25.1,31.0,37.3,40.6,48.8,54.6,114.9,125.3,127.9,130.0$, $143.8,156.0,157.5,169.0,169.7,171.3 \mathrm{ppm}$.

HRMS (ESI-TOF): calculated for $\mathrm{C}_{19} \mathrm{H}_{28} \mathrm{~N}_{5} \mathrm{O}_{5}[\mathrm{M}+\mathrm{H}]^{+}$406.2085; found 406.2070 .

IR (ATR) $v_{\text {max }}: 772,979,1245,1387,1643,1832,2714,2808,2936,3263 \mathrm{~cm}^{-1}$.

$[\alpha]_{D}^{25}:+4.45^{\circ}(c 1.0 ; \mathrm{MeOH})$.

5.8 (S)-7-guanidino-4-((S)-3-(4-hydroxyphenyl)-2-octanamidopropanamido)heptanoic acid (2,3,17,18-Tetrahydro Barnesin, 11)

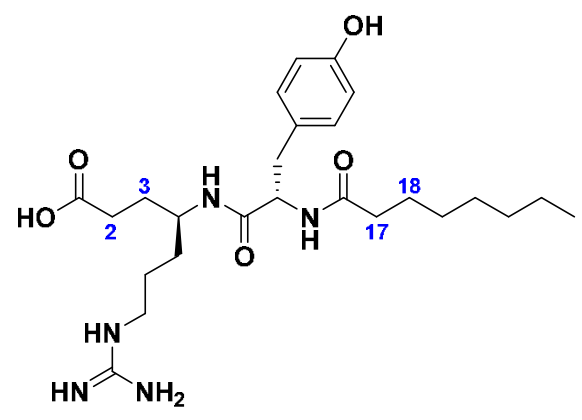
Following GP4 (Step 1 - Step 8) with VII $(0.89 \mathrm{mmol})$ and $1785 \mathrm{mg}$ of loaded resin gave 11 (crude product $~ 87 \mathrm{mg}$ ), which was furthermore introduced into the palladium catalyzed hydrogenation. Purification by semipreparative HPLC system yielded 11 (7.9 mg, $1.1 \%$ overall yield) as a white solid.

${ }^{1} \mathrm{H}-N M R\left(600 \mathrm{MHz}\right.$, DMSO- $\left.d_{6}\right): \delta=0.84(\mathrm{t}, J=7.06 \mathrm{~Hz}, 3 \mathrm{H})$, $1.09(\mathrm{~m}, 2 \mathrm{H}), 1.17(\mathrm{~m}, 4 \mathrm{H}), 1.23(\mathrm{~m}, 2 \mathrm{H}), 1.33(\mathrm{~m}, 1 \mathrm{H}), 1.35$ $(\mathrm{m}, 2 \mathrm{H}), 1.41(\mathrm{~m}, 2 \mathrm{H}), 1.48(\mathrm{~m}, 1 \mathrm{H}), 1.49(\mathrm{~m}, 1 \mathrm{H}), 1.65(\mathrm{~m}, 1 \mathrm{H}), 1.95(\mathrm{~m}, 2 \mathrm{H}), 2.01(\mathrm{~m}, 2 \mathrm{H}), 2.62(\mathrm{~m}$, $1 \mathrm{H}), 2.81(\mathrm{~m}, 1 \mathrm{H}), 3.01(\mathrm{~m}, 2 \mathrm{H}), 4.35(\mathrm{~m}, 1 \mathrm{H}), 4.64(\mathrm{~m}, 1 \mathrm{H}), 6.61(\mathrm{~d}, J=8.3 \mathrm{~Hz}, 2 \mathrm{H}), 6.99(\mathrm{~d}, J=8.3 \mathrm{~Hz}$,

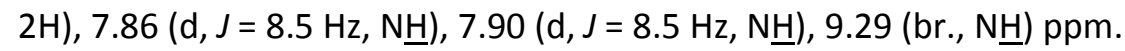

${ }^{13} \mathrm{C}-N M R\left(150 \mathrm{MHz}\right.$, DMSO- $\left.d_{6}\right): \delta=13.9,22.1,24.9,25.2,28.4,28.4,30.8,31.1,31.3,33.1,35.2,37.2$, $40.3,48.0,54.4,114.7,128.0,129.9,155.8,157.5,171.2,172.0,176.9$ ppm.

HRMS (ESI-TOF): calculated for $\mathrm{C}_{25} \mathrm{H}_{42} \mathrm{~N}_{5} \mathrm{O}_{5}[\mathrm{M}+\mathrm{H}]^{+} 492.3181$; found 492.3162 .

IR (ATR) $\mathbf{v}_{\text {max }}: 776,1026,1245,1391,1460,1643,1832,1863,2863,2929,3552,3683 \mathrm{~cm}^{-1}$.

$[\alpha]_{D}^{25}:+3.05^{\circ}(c 1.0 ; \mathrm{MeOH})$. 


\section{9 (S,E)-7-guanidino-4-((S)-2-((E)-oct-2-enamido)-3-phenylpropanamido)hept-2-enoic}

acid (Barnesin-L-Phenylalanine, 12)

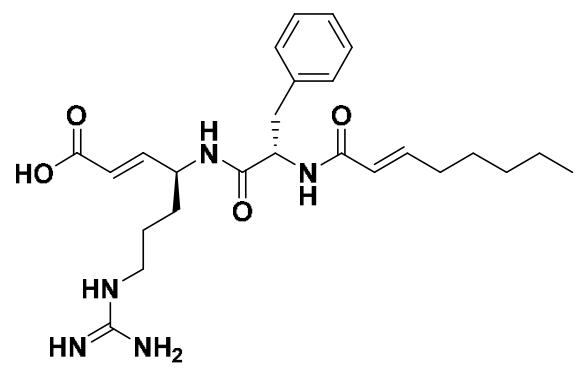

Following GP4 (Step 1 - Step 8) with VII $(1.50 \mathrm{mmol})$ and 500 $\mathrm{mg}$ of loaded resin, followed by a peptide coupling with Fmoc-L-Phe-OH (0.75 mmol, 3.0 eq.) in step 4 of GP4, yielded 12 (3.6 mg, $1.9 \%$ overall yield) as a white solid after purification on semipreparative HPLC.

${ }^{1} \mathrm{H}-\mathrm{NMR}\left(600 \mathrm{MHz}\right.$, DMSO- $\left.d_{6}\right): \delta=0.85(\mathrm{t}, J=7.0 \mathrm{~Hz}, 3 \mathrm{H}), 1.23$ $(\mathrm{m}, 2 \mathrm{H}), 1.27(\mathrm{~m}, 2 \mathrm{H}), 1.35(\mathrm{~m}, 2 \mathrm{H}), 1.39(\mathrm{~m}, 1 \mathrm{H}), 1.46(\mathrm{~m}, 2 \mathrm{H})$, $1.67(\mathrm{~m}, 1 \mathrm{H}), 2.06(\mathrm{q}, J=14.2,7.3 \mathrm{~Hz}, 2 \mathrm{H}), 2.71(\mathrm{~m}, 1 \mathrm{H}), 2.98(\mathrm{~m}, 1 \mathrm{H}), 3.07(\mathrm{~m}, 2 \mathrm{H}), 4.36(\mathrm{~m}, 2 \mathrm{H}), 4.56$ $(\mathrm{m}, 2 \mathrm{H}), 5.72(\mathrm{~d}, J=15.4 \mathrm{~Hz}, 1 \mathrm{H}), 5.89(\mathrm{~d}, J=15.5 \mathrm{~Hz}, 1 \mathrm{H}), 6.49(\mathrm{~m}, 2 \mathrm{H}), 7.16(\mathrm{~m}, 1 \mathrm{H}), 7.23(\mathrm{~m}, 4 \mathrm{H})$, $8.13(\mathrm{~d}, J=8.5 \mathrm{~Hz}, \mathrm{~N} \underline{\mathrm{H}}), 8.47$ (d, $J=8.47 \mathrm{~Hz}, \mathrm{~N} \underline{\mathrm{H}}), 9.79$ (br., N트) ppm.

${ }^{13}$ C-NMR (150 MHz, DMSO- $d_{6}$ ): $\delta=13.9,21.9,24.9,27.5,30.7,30.8,31.2,38.2,40.1,48.8,54.3$, $124.3,126.2,128.0,129.1,129.7,138.0,142.3,142.8,157.3,164.7,170.6,170.9$ ppm.

HRMS (ESI-TOF): calculated for $\mathrm{C}_{25} \mathrm{H}_{38} \mathrm{~N}_{5} \mathrm{O}_{4}[\mathrm{M}+\mathrm{H}]^{+} 472.2918$; found 472.2916 .

IR (ATR) $v_{\max }: 704,1194,1649,3156,3672 \mathrm{~cm}^{-1}$

$[\alpha]_{D}^{25}:-7.59^{\circ}$ (c 1.0; MeOH).

\subsection{Methyl (S,E)-8-amino-4-((S)-3-(4-hydroxyphenyl)-2-((E)-oct-2-}

\section{enamido)propanamido)oct-2-enoate (Barnesin-L-Lysin-OMe, 13)}

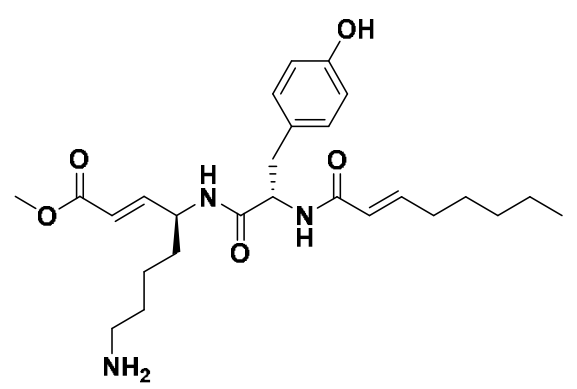

Following GP4 (Step 1 - Step 7) with IX (1.48 mmol) and 2950 $\mathrm{mg}$ of loaded resin yielded fully protected 16 , which was directly subjected to methylation following GP5 and after further deprotection yielded $\mathbf{1 3}$ (34 mg, $3.0 \%$ overall yield) as a white solid after purification on semipreparative HPLC.

${ }^{1} \mathrm{H}-\mathrm{NMR}$ (600 MHz, DMSO-d $\left.\mathbf{d}\right): \delta=0.86(\mathrm{t}, J=7.3 \mathrm{~Hz}, 3 \mathrm{H}), 1.27$ $(\mathrm{m}, 6 \mathrm{H}), 1.37(\mathrm{~m}, 2 \mathrm{H}), 1.42(\mathrm{~m}, 1 \mathrm{H}), 1.51(\mathrm{~m}, 2 \mathrm{H}), 1.57(\mathrm{~m}, 1 \mathrm{H})$, $2.09(\mathrm{q}, J=7.0,14.0 \mathrm{~Hz}, 2 \mathrm{H}), 2.68(\mathrm{dd}, J=9.2,13.4 \mathrm{~Hz}, 1 \mathrm{H}), 2.75(\mathrm{~m}, 2 \mathrm{H}), 2.83(\mathrm{dd}, J=5.4,13.9 \mathrm{~Hz}$, $1 \mathrm{H}), 3.65(\mathrm{~s}, 3 \mathrm{H}), 4.39(\mathrm{~m}, 1 \mathrm{H}), 4.45(\mathrm{~m}, 1 \mathrm{H}), 5.73(\mathrm{~d}, J=15.4 \mathrm{~Hz}, 1 \mathrm{H}), 5.95(\mathrm{~d}, J=14.4 \mathrm{~Hz}, 1 \mathrm{H}), 6.55$ (dt, $J=6.8,15.3 \mathrm{~Hz}, 1 \mathrm{H}), 6.62(\mathrm{~d}, J=8.5 \mathrm{~Hz}, 2 \mathrm{H}), 6.76(\mathrm{dd}, J=5.2,15.7 \mathrm{~Hz}, 1 \mathrm{H}), 7.01(\mathrm{~d}, J=8.5 \mathrm{~Hz}, 2 \mathrm{H})$,

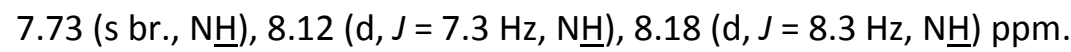

${ }^{13} \mathrm{C}-N M R\left(150 \mathrm{MHz}\right.$, DMSO- $\left.d_{6}\right): \delta=13.9,21.9,22.2,26.6,27.4,30.8,31.2,32.6,37.1,38.6,49.1,51.4$, 54.7, 114.9, 119.5, 124.1, 127.6, 130.0, 142.9, 149.1, 155.9, 164.8, 166.1, 171.1 ppm.

HRMS (ESI-TOF): calculated for $\mathrm{C}_{26} \mathrm{H}_{40} \mathrm{~N}_{3} \mathrm{O}_{4}[\mathrm{M}+\mathrm{H}]^{+} 474.2963$; found 474.2950 .

IR (ATR) $v_{\text {max }}: 989,1138,1194,1669,2860,2926 \mathrm{~cm}^{-1}$.

$[\alpha]_{D}^{25}:-9.46^{\circ}$ (c 1.0; MeOH). 


\subsection{Methyl (S,E)-8-amino-4-((S)-2-((E)-oct-2-enamido)-3-phenylpropanamido)oct-2-}

enoate (Barnesin-L-Lysin-OMe-L-Phenylalanine, 14)

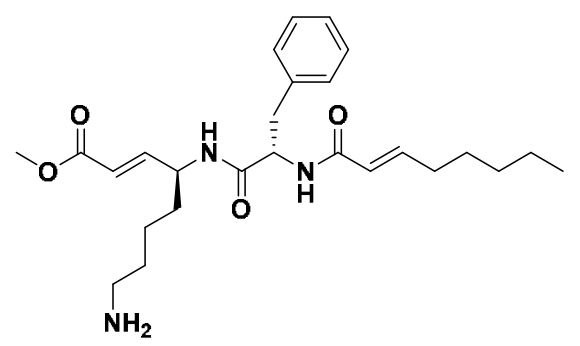

Following GP4 (Step 1 - Step 7) with IX $(1.58 \mathrm{mmol})$ and $1056 \mathrm{mg}$ of loaded resin yielded fully protected $\mathbf{1 5}$, which was directly subjected to methylation procedure according to GP5. Final deprotection yielded $\mathbf{1 4}$ (13 $\mathrm{mg}, 3.4 \%$ overall yield) as a white solid after purification on semipreparative HPLC.

${ }^{1} \mathrm{H}-\mathrm{NMR}\left(600 \mathrm{MHz}\right.$, DMSO-d $\left.d_{6}\right): \delta=0.85(\mathrm{t}, J=6.9 \mathrm{~Hz}, 3 \mathrm{H}), 1.25$ $(\mathrm{m}, 4 \mathrm{H}), 1.26(\mathrm{~m}, 2 \mathrm{H}), 1.37(\mathrm{~m}, 2 \mathrm{H}), 1.45(\mathrm{~m}, 3 \mathrm{H}), 1.54(\mathrm{~m}, 1 \mathrm{H}), 2.09(\mathrm{q}, J=6.9,14.2 \mathrm{~Hz}, 2 \mathrm{H}), 2.66(\mathrm{~m}$, $2 \mathrm{H}), 2.81(\mathrm{dd}, J=4.2,13.5 \mathrm{~Hz}, 1 \mathrm{H}), 2.95(\mathrm{dd}, J=5.5,13.6 \mathrm{~Hz}, 1 \mathrm{H}), 3.65(\mathrm{~s}, 3 \mathrm{H}), 4.38(\mathrm{~m}, 1 \mathrm{H}), 4.54(\mathrm{~m}$, $1 \mathrm{H}), 5.69(\mathrm{~d}, J=15.4 \mathrm{~Hz}, 1 \mathrm{H}), 5.95(\mathrm{~d}, J=15.4 \mathrm{~Hz}, 1 \mathrm{H}), 6.55(\mathrm{~m}, 1 \mathrm{H}), 6.74(\mathrm{dd}, J=5.3,15.5 \mathrm{~Hz}, 1 \mathrm{H})$, $7.17(\mathrm{~m}, 1 \mathrm{H}), 7.24(\mathrm{~m}, 4 \mathrm{H}), 8.28(\mathrm{~d}, J=7.5 \mathrm{~Hz}, \mathrm{NH}), 8.36(\mathrm{~d}, J=7.8 \mathrm{~Hz}, \mathrm{~N} \underline{\mathrm{H}}) \mathrm{ppm}$.

${ }^{13}$ C-NMR (150 MHz, DMSO-d $\left.d_{6}\right): \delta=13.9,21.9,22.4,27.4,28.3,30.8,31.2,33.7,37.8,39.1,49.2,51.3$, $54.5,119.3,124.1,126.3,128.0,129.1,137.7,142.9,149.2,164.8,165.8,171.0$ ppm.

HRMS (ESI-TOF): calculated for $\mathrm{C}_{26} \mathrm{H}_{40} \mathrm{~N}_{3} \mathrm{O}_{4}[\mathrm{M}+\mathrm{H}]^{+} 458.3013$; found 458.3012 .

IR (ATR) $v_{\max }: 1212,1543,1644,2860,2926 \mathrm{~cm}^{-1}$.

$[\alpha]_{D}^{25}:-6.51^{\circ}(c 1.0 ; \mathrm{MeOH})$.

\section{$5.12(S, E)-8$-amino-4-((S)-2-((E)-oct-2-enamido)-3-phenylpropanamido)oct-2-enoic acid} (Barnesin-L-Lysin-L-Phenylalanine, 15)

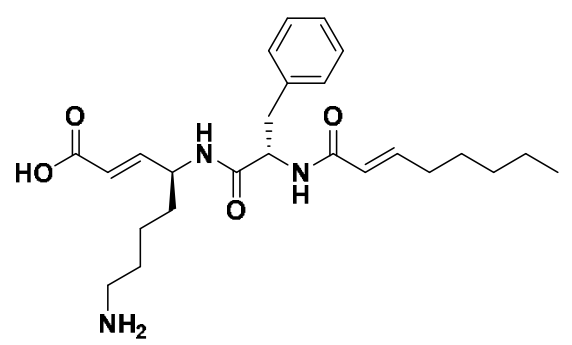

Following GP4 (Step 1 - Step 8) with IX $(1.25 \mathrm{mmol})$ and $835 \mathrm{mg}$ of loaded resin yielded 15 ( $4.8 \mathrm{mg}, 1.6 \%$ overall yield) as a white solid after purification on semipreparative HPLC.

${ }^{1} \mathrm{H}-\mathrm{NMR}\left(600 \mathrm{MHz}\right.$, DMSO-d $\left.\boldsymbol{d}_{6}\right): \delta=0.85(\mathrm{t}, J=6.6 \mathrm{~Hz}, 3 \mathrm{H}), 1.26$ $(\mathrm{m}, 6 \mathrm{H}), 1.36(\mathrm{~m}, 2 \mathrm{H}), 1.43(\mathrm{~m}, 1 \mathrm{H}), 1.50(\mathrm{~m}, 3 \mathrm{H}), 2.08(\mathrm{q}, J=$ $6.9,14.1 \mathrm{~Hz}, 2 \mathrm{H}), 2.69(\mathrm{t}, J=7.1 \mathrm{~Hz}, 2 \mathrm{H}), 2.78(\mathrm{dd}, J=10.2,13.4$ $\mathrm{Hz}, 1 \mathrm{H}), 2.97(\mathrm{dd}, J=4.7,13.7 \mathrm{~Hz}, 1 \mathrm{H}), 4.34(\mathrm{~m}, 1 \mathrm{H}), 4.55(\mathrm{~m}, 1 \mathrm{H}), 5.68(\mathrm{~d}, J=15.6 \mathrm{~Hz}, 1 \mathrm{H}), 5.93(\mathrm{~d}, J=$ $15.3 \mathrm{~Hz}, 1 \mathrm{H}), 6.50(\mathrm{~m}, 1 \mathrm{H}), 6.53(\mathrm{~m}, 1 \mathrm{H}), 7.16(\mathrm{~m}, 1 \mathrm{H}), 7.24(\mathrm{~m}, 4 \mathrm{H}), 8.26(\mathrm{~d}, J=8.3 \mathrm{~Hz}, 2 \mathrm{x} \mathrm{NH}) \mathrm{ppm}$.

${ }^{13} \mathrm{C}-N M R\left(150 \mathrm{MHz}\right.$, DMSO- $\left.d_{6}\right): \delta=13.9,21.9,22.2,27.4,27.6,30.8,31.1,33.3,37.9,38.8,49.1,54.3$, $124.2,124.7,142.9,126.3,128.0,129.2,137.9,144.2,164.8,168.5,170.9$ ppm.

HRMS (ESI-TOF): calculated for $\mathrm{C}_{25} \mathrm{H}_{38} \mathrm{~N}_{3} \mathrm{O}_{4}[\mathrm{M}+\mathrm{H}]^{+} 444.2857$; found 444.2860 .

IR (ATR) $v_{\text {max }}: 983,1397,1627,1794,2683,2850,3278 \mathrm{~cm}^{-1}$.

$[\alpha]_{D}^{25}:-3.95^{\circ}(c 1.0 ; \mathrm{MeOH})$. 
$5.13(S, E)-8$-amino-4-((S)-3-(4-hydroxyphenyl)-2-((E)-oct-2-enamido)propanamido)oct-2enoic acid (Barnesin-L-Lysin, 16)

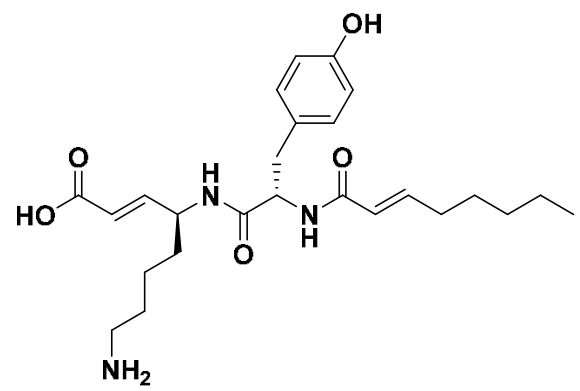

Following GP4 (Step 1 - Step 8) with IX $(0.72 \mathrm{mmol})$ and $384 \mathrm{mg}$ of loaded resin yielded 16 (17.1 $\mathrm{mg}, 9.7 \%$ overall yield) as a white solid after purification on semipreparative HPLC.

${ }^{1} \mathrm{H}-\mathrm{NMR}\left(600 \mathrm{MHz}, \mathrm{D}_{2} \mathrm{O}\right): \delta=1.25(\mathrm{~m}, 4 \mathrm{H}), 1.26(\mathrm{~m}, 2 \mathrm{H}), 1.35$ $(\mathrm{m}, 2 \mathrm{H}), 1.41(\mathrm{~m}, 2 \mathrm{H}), 1.44(\mathrm{~m}, 2 \mathrm{H}), 2.09(\mathrm{~m}, 2 \mathrm{H}), 2.63(\mathrm{~m}, 2 \mathrm{H})$, $2.69(\mathrm{~m}, 1 \mathrm{H}), 2.87(\mathrm{~m}, 1 \mathrm{H}), 4.31(\mathrm{~m}, 1 \mathrm{H}), 4.48(\mathrm{~m}, 1 \mathrm{H}), 5.70(\mathrm{~d}$, $J=15.6 \mathrm{~Hz}, 1 \mathrm{H}), 5.94(\mathrm{~d}, J=15.5 \mathrm{~Hz}, 1 \mathrm{H}), 6.43(\mathrm{dd}, J=15.6,5.0 \mathrm{~Hz}, 1 \mathrm{H}), 6.55(\mathrm{dt}, J=15.5,6.8 \mathrm{~Hz}, 1 \mathrm{H})$, $6.62(\mathrm{~d}, J=6.8 \mathrm{~Hz}, 2 \mathrm{H}), 7.01(\mathrm{~d}, J=8.1 \mathrm{~Hz}, 2 \mathrm{H}), 7.99(\mathrm{~m}, 2 \times \mathrm{NH}) \mathrm{ppm}$.

${ }^{13} \mathrm{C}$-NMR (150 MHz, D2O): $\delta=13.6,21.7,22.3,27.3,29.3,30.6,31.0,33.5,37.0,38.8,49.2,54.4$, $114.8,124.2,127.7,127.8,129.8,142.6(2 x), 155.7,164.7,170.7(2 x)$ ppm.

HRMS (ESI-TOF): calculated for $\mathrm{C}_{25} \mathrm{H}_{38} \mathrm{~N}_{3} \mathrm{O}_{5}[\mathrm{M}+\mathrm{H}]^{+} 460.2806$; found 460.2807 .

IR (ATR) V $V_{\text {max }}: 989,1136,1192,1613,2672,2861,2930,3056,3268 \mathrm{~cm}^{-1}$.

$[\alpha]_{D}^{25}:-8.78^{\circ}(c 1.0 ; \mathrm{MeOH})$.

\section{$5.14(R, E)-8$-amino-4-((S)-3-(4-hydroxyphenyl)-2-((E)-oct-2-enamido)propanamido)oct-2-} enoic acid (Barnesin-D-Lysin, 17)

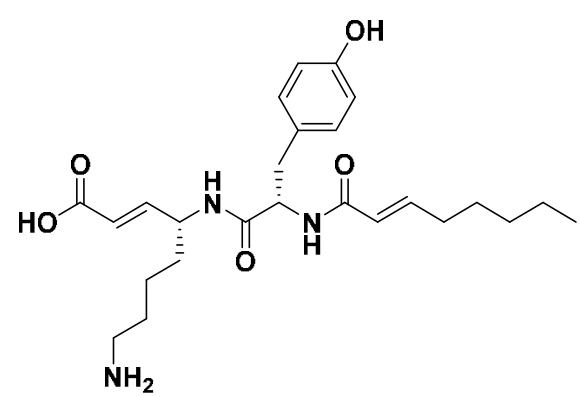

Following GP4 (Step 1 - Step 8) with $\mathbf{X}(0.75 \mathrm{mmol})$ and $500 \mathrm{mg}$ of loaded resin yielded $\mathbf{1 7}$ (7.0 $\mathrm{mg}, 3.8 \%$ overall yield) as a white solid after purification on semipreparative HPLC.

${ }^{1} \mathrm{H}-\mathrm{NMR}\left(600 \mathrm{MHz}\right.$, DMSO-d $\left.\mathbf{d}_{6}\right): \delta=0.86(\mathrm{t}, J=7.0 \mathrm{~Hz}, 3 \mathrm{H}), 1.25$ $(\mathrm{m}$, “ $\mathrm{H}), 1.27(\mathrm{~m}, 4 \mathrm{H}), 1.37(\mathrm{~m}, 2 \mathrm{H}), 1.44(\mathrm{~m}, 1 \mathrm{H}), 1.51(\mathrm{~m}, 2 \mathrm{H})$, $1.57(\mathrm{~m}, 1 \mathrm{H}), 2.09(\mathrm{q}, J=6.8,13.93 \mathrm{~Hz}, 2 \mathrm{H}), 2.67(\mathrm{~m}, 1 \mathrm{H}), 2.75$ $(\mathrm{t}, J=7.57 \mathrm{~Hz}, 2 \mathrm{H}), 2.85(\mathrm{~m}, 1 \mathrm{H}), 4.39(\mathrm{~m}, 2 \mathrm{H}), 4.45(\mathrm{~m}, 2 \mathrm{H})$, $5.73(\mathrm{dd}, J=15.7,1.5 \mathrm{~Hz}, 1 \mathrm{H}), 5.95(\mathrm{~d}, J=15.4 \mathrm{~Hz}, 1 \mathrm{H}), 6.54$ (dt, $J=15.5,7.1 \mathrm{~Hz}, 1 \mathrm{H}), 6.62(\mathrm{~d}, J=8.3 \mathrm{~Hz}, 2 \mathrm{H}), 6.70(\mathrm{dd}, J=15.7,5.5 \mathrm{~Hz}, 1 \mathrm{H}), 7.03(\mathrm{~d}, J=8.3 \mathrm{~Hz}, 2 \mathrm{H}$ ),

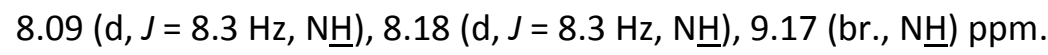

${ }^{13} \mathrm{C}$-NMR (150 MHz, DMSO-d $\left.d_{6}\right): \delta=13.9,21.9,22.2,27.4,30.8,31.1,32.8,36.6,37.1,38.7,49.1,54.6$, $114.9,121.2,124.2,127.8,130.0,142.9,147.9,155.8,164.8,167.1,171.1 \mathrm{ppm}$.

HRMS (ESI-TOF): calculated for $\mathrm{C}_{25} \mathrm{H}_{38} \mathrm{~N}_{3} \mathrm{O}_{5}[\mathrm{M}+\mathrm{H}]^{+} 460.2806$; found 460.2794 .

IR (ATR) V $\max : 1106,1248,1387,1634,1651,1732,2836,2925,2947,3273,3351 \mathrm{~cm}^{-1}$. $[\alpha]_{D}^{25}:-11.91^{\circ}$ (c 1.0; MeOH). 


\section{Bioactivity studies}

\subsection{Enzymatic assays}

The determination of the activity of the inhibitors against hCatL and RD was performed in fluorescence-based assays. In the following, the procedure for the hCatL inhibition assay is described in detail. The assays with rhodesain were carried out using the same procedure. ${ }^{9}$

Table S1. Inhibitory activity ( $\left(\mathrm{C}_{50}\right.$ values* and $\mathrm{K}_{\mathrm{i}}$ values**) of synthesized compounds against cathepsin $\mathrm{L}$ and rhodesain.

\begin{tabular}{|c|c|c|c|c|c|c|}
\hline \multirow{2}{*}{ Cpd } & \multicolumn{2}{|c|}{$\mathbf{I C}_{\mathbf{5 0}}(\boldsymbol{\mu M})^{*}$} & \multicolumn{2}{c|}{ Cathepsin $\mathbf{L}^{* *}$} & \multicolumn{2}{c|}{ Rhodesain** $^{*}$} \\
\cline { 2 - 7 } & hCatL & $\mathbf{R d}$ & $\mathbf{K}_{\mathbf{i}}[\boldsymbol{\mu} \mathbf{M}]$ & $\mathbf{k}_{\mathbf{2 n d}}\left[\mathbf{M}^{-1} \mathbf{s}^{-1}\right]$ & $\mathbf{K}_{\mathbf{i}}[\boldsymbol{\mu M}]$ & $\mathbf{k}_{\mathbf{2 n d}}\left[\mathbf{M}^{-1} \mathbf{s}^{-1}\right]$ \\
\hline $\mathbf{1}$ & 3.50 & 0.37 & $1.5 \pm 0.39$ & $2216 \pm 347$ & $0.081 \pm 0.013$ & $144427 \pm 23974$ \\
\hline $\mathbf{5}$ & n.d. & 18.30 & n.d. & n.d. & $3.6 \pm 1.0$ & $2130 \pm 144$ \\
\hline $\mathbf{6}$ & n.d. & n.d. & n.d. & n.d. & n.d. & n.d. \\
\hline $\mathbf{7}$ & n.d. & n.d. & n.d. & n.d. & n.d. & n.d. \\
\hline $\mathbf{8}$ & 7.60 & 0.52 & $7.0 \pm 2.1$ & $749 \pm 85$ & $0.080 \pm 0.012$ & $84579 \pm 7358$ \\
\hline $\mathbf{9}$ & n.d. & 11.4 & n.d. & n.d. & $2.8 \pm 1.1$ & $6847 \pm 1627$ \\
\hline $\mathbf{1 0}$ & 53.00 & 12.10 & $35 \pm 7.6$ & $105 \pm 10$ & $0.91 \pm 0.34$ & $4862 \pm 736$ \\
\hline $\mathbf{1 1}$ & n.d. & n.d. & n.d. & n.d. & n.d. & n.d. \\
\hline $\mathbf{1 2}$ & 6.20 & 0.42 & $6.4 \pm 2.2$ & $1110 \pm 601$ & $0.075 \pm 0.017$ & $104631 \pm 14066$ \\
\hline $\mathbf{1 3}$ & 3.75 & 2.75 & $1.9 \pm 0.4$ & $3004 \pm 292$ & $0.21 \pm 0.049$ & $54716 \pm 5982$ \\
\hline $\mathbf{1 4}$ & 0.093 & 0.32 & $0.047 \pm 0.005$ & $103802 \pm 1573$ & $0.024 \pm 0.005$ & $797250 \pm 151069$ \\
\hline $\mathbf{1 5}$ & 4.0 & 0.7 & $4.3 \pm 1.0$ & $1704 \pm 167$ & $0.048 \pm 0.01$ & $157543 \pm 25248$ \\
\hline $\mathbf{1 6}$ & 0.65 & 0.22 & $0.11 \pm 0.02$ & $22436 \pm 897$ & $0.012 \pm 0.005$ & $673809 \pm 32619$ \\
\hline $\mathbf{1 7}$ & 9.2 & 0.28 & $4.2 \pm 0.39$ & $904 \pm 43$ & $0.045 \pm 0.02$ & $239099 \pm 85338$ \\
\hline
\end{tabular}

Table S2. Representative protease inhibition assays of barnesin A (1) and its derivatives in comparison to reported inhibitors.
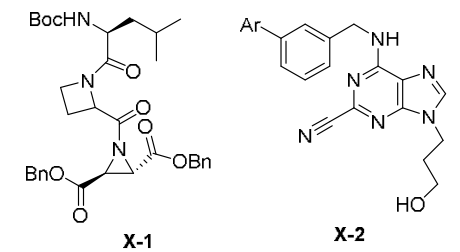<smiles>NC(=S)N/N=C/c1ccc(Cl)c(Cl)c1</smiles>

\begin{tabular}{|c|c|c|c|c|c|c|}
\hline Compound & Papain[a] & Ficin[a] & Cathepsin $\mathrm{B}^{[\mathrm{b}]}$ & Trypsinc & Cat $L^{d}$ & $\mathrm{Rd}^{\mathrm{d}}$ \\
\hline Barnesin A (1) & $\begin{array}{l}15.96 \mu \mathrm{M} \\
( \pm 5.8)\end{array}$ & $\begin{array}{l}3.43 \mu \mathrm{M} \\
( \pm 0.15)\end{array}$ & $\begin{array}{l}91.72 \mathrm{nM} \\
( \pm 3,29)\end{array}$ & $>2000 \mu \mathrm{M}$ & $3.50 \mu \mathrm{M}$ & $0.37 \mu \mathrm{M}$ \\
\hline Derivative (14) & n.t. & n.t. & n.t. & n.t. & $0.093 \mu \mathrm{M}$ & $0.32 \mu \mathrm{M}$ \\
\hline Derivative (15) & n.t. & n.t. & n.t. & n.t. & $4.00 \mu \mathrm{M}$ & $0.70 \mu \mathrm{M}$ \\
\hline Derivative (16) & n.t. & n.t. & n.t. & n.t. & $0.65 \mu \mathrm{M}$ & $0.22 \mu \mathrm{M}$ \\
\hline Compound $\mathbf{X}-\mathbf{1}^{10, \mathrm{e}}$ & n.r. & n.r. & & n.r. & $3.8 \mu \mathrm{M}$ & $0.8 \mu \mathrm{M}$ \\
\hline Compound $\mathbf{X}-\mathbf{2}^{11}$ & n.r. & n.r. & $\begin{array}{l}8.4 \mu \mathrm{M} \\
( \pm 0.8)\end{array}$ & n.r. & $\begin{array}{l}0.8 \mu \mathrm{M} \\
( \pm 0.3)\end{array}$ & $\begin{array}{l}0.7 \mu \mathrm{M} \\
( \pm 0.2)\end{array}$ \\
\hline Compound $\mathbf{X}-\mathbf{3}^{12}$ & n.r. & n.r. & n.r. & n.r. & n.r. & $0.038 \mu \mathrm{M}$ \\
\hline E-64 $13-15$ & $0.29 \mu \mathrm{M}$ & & $0.035 \mu \mathrm{M}$ & & $0.05 \mu \mathrm{M}$ & \\
\hline Kojistatin $\mathrm{A}^{16}$ & $0.0082 \mu \mathrm{M}$ & & $0.0018 \mu \mathrm{M}$ & & $0.0048 \mu \mathrm{M}$ & \\
\hline Leupeptin ${ }^{17}$ & $0.86 \mu \mathrm{M}$ & n.r. & $21.5 \mathrm{nM}$ & $2.2 \mu \mathrm{M}$ & & \\
\hline Miraziridin $\mathrm{A}^{18,19}$ & n.r. & n.r. & $2.05 \mu \mathrm{M}$ & $60 \mu \mathrm{M}$ & & \\
\hline
\end{tabular}


Control reactions: inhibition: a) iodacetamide (2 mM): $98.83 \%$ inhibition of papain; $97.35 \%$ inhibition of ficin; b) leupeptin (1.5 $\mathrm{mM}$ ): $99.86 \%$ inhibition of cathepsin B; c) PMF (2 mM): $100 \%$ inhibition of trypsin; d) determined activity as IC 50 values in $\mu M$ of the inhibitors against $C a t \mathrm{~L}$ and $\mathrm{Rd}$; e) $K_{i}$ inhibitory activity at $\mu \mathrm{M} ; \mathrm{n} . r .=$ not reported in literature; $\mathrm{n} . \mathrm{t} .=$ not tested.

\subsection{Microsome Stability Assays (HML)}

\section{General procedure for HML assays}

\section{$\underline{\text { Test item }}$}

- $360 \mu \mathrm{L}$ Microsomal solution

- $\quad 360 \mu \mathrm{L}$ NADP-regeneration mix

- $\quad 40 \mu \mathrm{L}$ Phosphate buffer

- Addition of $10 \mu \mathrm{L}$ WS1 of the test item to the pre-incubated solution at $37^{\circ} \mathrm{C} / 1500 \mathrm{rpm}$

\section{Negativ control (NC)}

- $760 \mu \mathrm{L}$ phosphate buffer

- Addition of $40 \mu \mathrm{L}$ WS1 of the test item to the pre-incubated solution at $37^{\circ} \mathrm{C} / 1500 \mathrm{rpm}$

\section{Positiv control (PC)}

- $360 \mu \mathrm{L}$ Microsomal solution

- $\quad 360 \mu \mathrm{L}$ NADP-regeneration mix

- $\quad 40 \mu \mathrm{L}$ Phosphate buffer

- Addition of $10 \mu \mathrm{L}$ WS1 of diclofenac to the pre-incubated solution at $37^{\circ} \mathrm{C} / 1500 \mathrm{rpm}$

\section{Preparation of samples}

- Proteine precipitation by addition of $100 \mu \mathrm{L} \mathrm{ACN}$ to $100 \mu \mathrm{L}$ aliquots of the assay mixture at $\mathrm{t}=0,30$ and $90 \mathrm{~min}$ in case of the test item, $\mathrm{t}=0$ and $30 \mathrm{~min}$ in case of $\mathrm{PC}$ and $\mathrm{t}=0$ and $90 \mathrm{~min}$ in case of NC

- $\quad 2$ min mixing at $1500 \mathrm{rpm}, 2$ min centrifugation at $16.1 \mathrm{krcf}$

- Injection of $5 \mu \mathrm{L}$ samples of the supernatant to UPLC/HRMS system

- Determination of the peak areas of the extracted ion chromatograms

\subsection{Glutathione Stability Assays (GSH)}

\section{General procedure for GSH assays}

Test item

- $720 \mu \mathrm{L}$ Phosphate buffer

- $\quad 40 \mu \mathrm{L} \mathrm{GSH}$ solution

- Addition of $40 \mu \mathrm{L}$ WS1 of the test item/PC (internal lab standard) to the pre-incubated solution at $37^{\circ} \mathrm{C} / 1500 \mathrm{rpm}$

Negativ control (NC)

- $760 \mu \mathrm{L}$ phosphate buffer

- Addition of $40 \mu \mathrm{L}$ WS1 of the test item to the pre-incubated solution at $37^{\circ} \mathrm{C} / 1500 \mathrm{rpm}$

\section{Preparation of samples}

- Addition of $100 \mu \mathrm{L} \mathrm{ACN}$ to $100 \mu \mathrm{L}$ aliquots of the assay mixture at $t=0,30$ and $90 \mathrm{~min}$ in case of the test item, $\mathrm{t}=0$ and $90 \mathrm{~min}$ in case of PC or NC

- 2 min mixing at $1500 \mathrm{rpm}, 2$ min centrifugation at $16.1 \mathrm{krcf}$ 
- Injection of $5 \mu \mathrm{L}$ samples of the supernatant to UPLC/HRMS system

- Determination of the peak areas of the extracted ion chromatogram

Table S3. Results of HML assays

\begin{tabular}{|c|c|c|c|c|c|c|c|}
\hline \multirow[t]{2}{*}{ Cpd } & \multirow[t]{2}{*}{ Type } & \multicolumn{3}{|c|}{ Area rel. } & \multicolumn{3}{|c|}{ Area rel. (\%) } \\
\hline & & $0 \mathrm{~min}$ & $30 \mathrm{~min}$ & $90 \mathrm{~min}$ & $0 \mathrm{~min}$ & $30 \mathrm{~min}$ & $90 \mathrm{~min}$ \\
\hline \multirow[t]{2}{*}{1} & PC & 1.000 & 0.883 & 0.834 & 100.0 & 88.3 & 83.4 \\
\hline & NC & 1.000 & & 0.923 & 100.0 & & 92.3 \\
\hline \multirow[t]{2}{*}{5} & PC & 1.000 & 0.793 & 0.675 & 100.0 & 79.3 & 67.5 \\
\hline & NC & 1.000 & & 1.028 & 100.0 & & 102.8 \\
\hline \multirow[t]{2}{*}{6} & $\mathrm{PC}$ & 1.000 & 0.894 & 0.871 & 100.0 & 89.4 & 87.1 \\
\hline & NC & 1.000 & & 1.058 & 100.0 & & 105.8 \\
\hline \multirow[t]{2}{*}{$7 *$} & PC & 1.000 & 0.710 & 0.903 & 100.0 & 71.0 & 90.3 \\
\hline & $\mathrm{NC}$ & 1.000 & & 0.063 & & & 6.3 \\
\hline \multirow[t]{2}{*}{8} & PC & 1.000 & 0.927 & 0.920 & 100.0 & 92.7 & 92.0 \\
\hline & NC & 1.000 & & 1.043 & 100.0 & & 104.3 \\
\hline \multirow[t]{2}{*}{9} & $\mathrm{PC}$ & 1.000 & 1.0291 & 1.0359 & 100.0 & 102.91 & 103.59 \\
\hline & NC & 1.000 & & 1.3171 & & & 131.71 \\
\hline \multirow[t]{2}{*}{10} & PC & 1.000 & 1.1064 & 1.0452 & 100.0 & 110.64 & 104.52 \\
\hline & NC & 1.000 & & 1.7208 & 100.0 & & 172.08 \\
\hline \multirow[t]{2}{*}{11} & PC & 1.000 & 0.956 & 0.982 & 100.0 & 95.6 & 98.2 \\
\hline & NC & 1.000 & & 0.995 & 100.0 & & 99.5 \\
\hline \multirow[t]{2}{*}{12} & PC & 1.000 & 0.852 & 0.794 & 100.0 & 85.2 & 79.4 \\
\hline & NC & 1.000 & & 0.892 & 100.0 & & 89.2 \\
\hline \multirow[t]{2}{*}{13} & PC & 1.000 & 0.472 & 0.2451 & 100.0 & 47.20 & 24.51 \\
\hline & NC & 1.000 & & 0.8621 & 100.0 & & 86.21 \\
\hline \multirow[t]{2}{*}{14} & PC & 1.000 & 0.0848 & 0.0205 & 100.0 & 8.48 & 2.05 \\
\hline & NC & 1.000 & & 0.6224 & 100.0 & & 62.24 \\
\hline \multirow[t]{2}{*}{15} & PC & 1.000 & 0.990 & 1.008 & 100.0 & 99.0 & 100.8 \\
\hline & NC & 1.000 & & 0.975 & 100.0 & & 97.5 \\
\hline \multirow[t]{2}{*}{16} & PC & 1.000 & 1.002 & 1.028 & 100.0 & 100.2 & 102.8 \\
\hline & NC & 1.000 & & 1.097 & 100.0 & & 109.7 \\
\hline \multirow[t]{2}{*}{17} & PC & 1.000 & 0.826 & 0.797 & 100.0 & 82.6 & 79.7 \\
\hline & $\mathrm{NC}$ & 1.000 & & 0.923 & 100.0 & & 92.3 \\
\hline
\end{tabular}

Positive control/ tested substance (PC), Negative control (NC), * poor solubility of the sample might cause variations in final concentrations. 
Table S4. Results of GSH assays

\begin{tabular}{|c|c|c|c|c|c|c|c|}
\hline \multirow[t]{2}{*}{ Cpd } & \multirow[t]{2}{*}{ Type } & \multicolumn{3}{|c|}{ Area rel. } & \multicolumn{3}{|c|}{ Area rel. (\%) } \\
\hline & & $0 \mathrm{~min}$ & $30 \mathrm{~min}$ & $90 \mathrm{~min}$ & $0 \mathrm{~min}$ & $30 \mathrm{~min}$ & $90 \mathrm{~min}$ \\
\hline \multirow[t]{2}{*}{1} & PC & 1.000 & 0.933 & 0.942 & 100.0 & 93.3 & 94.2 \\
\hline & $N C$ & 1.000 & & & 100.0 & & 91.9 \\
\hline \multirow[t]{2}{*}{5} & PC & 1.000 & & 0.993 & 100.0 & & 99.3 \\
\hline & NC & & & & & & \\
\hline \multirow[t]{2}{*}{6} & PC & 1.000 & & 0.986 & 100.0 & & 98.6 \\
\hline & $\mathrm{NC}$ & 1.000 & & 0.919 & 100.0 & & 91.9 \\
\hline \multirow[t]{2}{*}{ 7* } & PC & 1.000 & 0.163 & 0.934 & 100.0 & 16.3 & 93.4 \\
\hline & $N C$ & 1.000 & & 0.168 & 100.0 & & 16.8 \\
\hline \multirow[t]{2}{*}{8} & $P C$ & 1.000 & & 1.037 & 100.0 & & 103.7 \\
\hline & $\mathrm{NC}$ & & & & & & \\
\hline \multirow[t]{2}{*}{9} & PC & 1.000 & 1.0082 & 0.9899 & 100.0 & 100.82 & 98.99 \\
\hline & $\mathrm{NC}$ & 1.000 & & 1.0562 & 100.0 & & 105.62 \\
\hline \multirow[t]{2}{*}{10} & PC & 1.000 & 1.176 & 1.1495 & 100.0 & 117.6 & 114.95 \\
\hline & NC & 1.000 & & 0.9336 & 100.0 & & 93.36 \\
\hline \multirow[t]{2}{*}{11} & PC & 1.000 & & 1.029 & 100.0 & & 102.9 \\
\hline & $N C$ & & & & & & \\
\hline \multirow[t]{2}{*}{12} & PC & 1.000 & 1.027 & 1.062 & 100.0 & 102.7 & 106.2 \\
\hline & $\mathrm{NC}$ & 1.000 & & 1.018 & 100.0 & & 101.8 \\
\hline \multirow[t]{2}{*}{13} & PC & 1.000 & 0.7644 & 0.5347 & 100.0 & 76.44 & 53.47 \\
\hline & NC & 1.000 & & 0.7095 & 100.0 & & 70.95 \\
\hline \multirow[t]{2}{*}{14} & PC & 1.000 & 0.8516 & 0.7587 & 100.0 & 85.16 & 75.87 \\
\hline & $N C$ & 1.000 & & 0.6789 & 100.0 & & 67.89 \\
\hline \multirow[t]{2}{*}{15} & PC & 1.000 & & 1.021 & 100.0 & & 102.1 \\
\hline & NC & 1.000 & & 1.020 & 100.0 & & 102.0 \\
\hline \multirow[t]{2}{*}{16} & PC & 1.000 & & 0.968 & 100.0 & & 96.8 \\
\hline & $\mathrm{NC}$ & 1.000 & & 1.006 & 100.0 & & 100.6 \\
\hline \multirow[t]{2}{*}{17} & PC & 1.000 & 1.043 & 0.980 & 100.0 & 104.3 & 98.0 \\
\hline & NC & 1.000 & & 1.039 & & & 103.9 \\
\hline
\end{tabular}

Positive control/ tested substance (PC), Negative control (NC), * poor solubility of the sample might cause variations in final concentrations. 


\section{NMR Tables}

Table S5. NMR table of (S,E)-7-guanidino-4-((S)-3-(4-hydroxyphenyl)-2-((E)-oct-2enamido)propanamido)hep-2-enoic acid (Barnesin A, 1) in $d_{6}$-DMSO at $26^{\circ} \mathrm{C}$

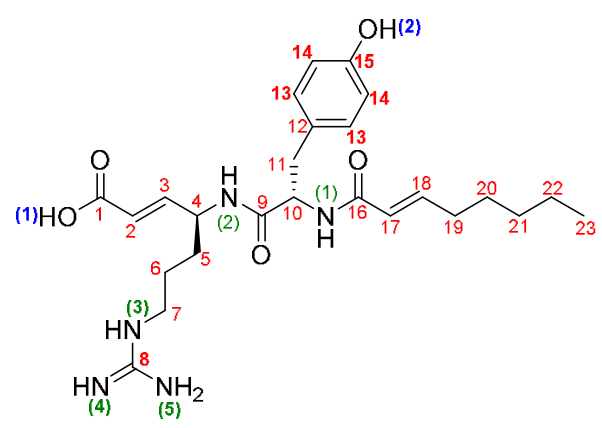

\begin{tabular}{|c|c|c|c|c|}
\hline position & $\delta_{\mathrm{H}}$, mult. $(J$ in $\mathrm{Hz})$ & $\delta_{c}$, type $^{b}$ & COSY & $\mathrm{HMBC}$ \\
\hline 1 & & 169.7, qC & & \\
\hline 2 & $5.73, d(15.4)$ & 124.7, CH & 3 & 1,4 \\
\hline 3 & $6.46, \mathrm{dd}(15.7,4.8)$ & $144.3, \mathrm{CH}$ & 2,4 & $1,2,4$ \\
\hline 4 & $4.34, \mathrm{~m}$ & $48.9, \mathrm{CH}$ & $3,5, N H(2)$ & \\
\hline $5 a$ & $1.46^{\mathrm{d}}, \mathrm{m}$ & $30.7, \mathrm{CH}_{2}$ & $4,5 b, 6$ & \\
\hline $5 b$ & $1.69, \mathrm{~m}$ & & $4,5 a$ & 6 \\
\hline 6 & $1.45, \mathrm{~m}$ & $24.9, \mathrm{CH}_{2}$ & $5 a, 5 b, 7$ & $4,5,7$ \\
\hline 7 & $3.06, \mathrm{~m}$ & $40.4^{\mathrm{c}}, \mathrm{CH}_{2}$ & 6 & 6,8 \\
\hline 8 & & $157.4, \mathrm{qC}$ & & \\
\hline 9 & & $171.1, q C$ & & \\
\hline 10 & $4.47, \mathrm{~m}$ & $54.6, \mathrm{CH}$ & $11 a, 11 b, N H(1)$ & $9,11,12,16$ \\
\hline $11 a$ & $2.87, \mathrm{~m}$ & 37.3, $\mathrm{CH}_{2}$ & $10,11 b$ & 10,12 \\
\hline $11 b$ & 2.59, m & & $10,11 a$ & 10,12 \\
\hline 12 & & 128.0, qC & & \\
\hline 13 & $7.00, d(8.3)$ & $129.9, \mathrm{CH}$ & 14 & $11,13,14,15$ \\
\hline 14 & $6.60, d(8.2)$ & $114.8, \mathrm{CH}$ & 13 & $13,14,15$ \\
\hline 15 & & 155.7, qC & & \\
\hline 16 & & 164.7, qC & & \\
\hline 17 & $5.90, d(15.3)$ & $124.3, \mathrm{CH}$ & 18,19 & 16 \\
\hline 18 & $6.50, \mathrm{dt}(15.4,6.8)$ & $142.6, \mathrm{CH}$ & 17,19 & $16,17,19$ \\
\hline 19 & $2.08, \mathrm{~m}$ & $31.1, \mathrm{CH}_{2}$ & 18,20 & $17,18,20,21$ \\
\hline 20 & $1.35, \mathrm{~m}$ & $27.5, \mathrm{CH}_{2}$ & 19 & $18,20,21$ \\
\hline 21 & $1.27, \mathrm{~m}$ & $30.8, \mathrm{CH}_{2}$ & & $20,22,23$ \\
\hline 22 & $1.23, \mathrm{~m}$ & 21.9, $\mathrm{CH}_{2}$ & 23 & $20,21,23$ \\
\hline 23 & $0.85, \mathrm{t}(6.7)$ & $13.9, \mathrm{CH}_{3}$ & 22 & 21,22 \\
\hline $\mathrm{NH}(3)$ & 9.80, br. S & & 7 & \\
\hline $\mathrm{NH}(2)$ & $8.46, d(7.9)$ & & 4 & 9 \\
\hline $\mathrm{NH}(1)$ & $8.05, d(8.5)$ & & 10 & $10,11,16$ \\
\hline
\end{tabular}

${ }^{a} 600 \mathrm{MHz}$ for ${ }^{1} \mathrm{H}$ NMR, COSY, HSQC and HMBC; $150 \mathrm{MHz}$ for ${ }^{13} \mathrm{C}$ NMR ; ${ }^{\mathrm{b}}$ numbers of attached protons were determined by COSYd and HMBC, HSQC 
Table S6. NMR table of (R,E)-7-guanidino-4-((S)-3-(4-hydroxyphenyl)-2-((E)-oct-2enamido)propanamido)hept-2-enoic acid (Barnesin-D-Arginine-L-Tyrosine, 5) ) in $d_{6}$-DMSO at $26^{\circ} \mathrm{C}$

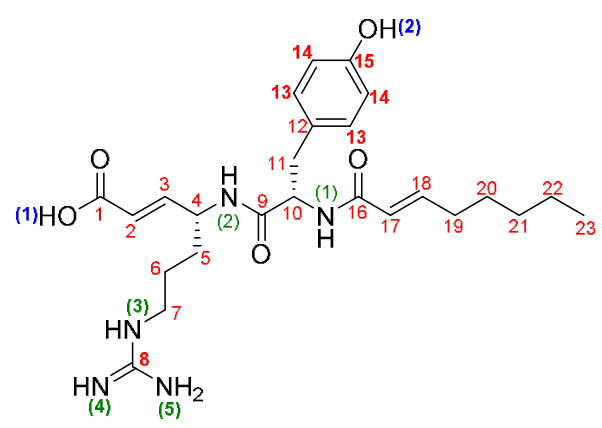

\begin{tabular}{|c|c|c|c|c|}
\hline position & $\delta_{\mathrm{H}}$, mult. $(\mathrm{J}$ in $\mathrm{Hz})$ & $\delta_{c}$, type $^{b}$ & COSY & HMBC \\
\hline \multicolumn{5}{|l|}{1} \\
\hline 2 & $5.70, d(15.5)$ & $128.7, \mathrm{CH}$ & 2 & 1,4 \\
\hline 3 & $6.37, \mathrm{dd}(15.9,5.3)$ & $141.2, \mathrm{CH}$ & 2,4 & $1,2,4$ \\
\hline 4 & $4.29, \mathrm{~m}$ & $48.7, \mathrm{CH}$ & $\mathrm{NH}(2)$ & \\
\hline $5 a$ & $1.58^{\mathrm{d}}, \mathrm{m}$ & $30.9, \mathrm{CH}_{2}$ & $5 b, 6$ & \\
\hline $5 b$ & $1.45, \mathrm{~m}$ & & $5 a, 6$ & 6 \\
\hline 6 & $1.29, \mathrm{~m}$ & $22.1, \mathrm{CH}_{2}$ & $5 a, 5 b, 7$ & $4,5,7$ \\
\hline 7 & $2.97, \mathrm{~m}$ & $40.4^{c}, \mathrm{CH}_{2}$ & 6 & 6,8 \\
\hline \multicolumn{5}{|l|}{8} \\
\hline 9 & & $170.8, q C$ & & \\
\hline 10 & $4.52, \mathrm{~m}$ & $54.6, \mathrm{CH}$ & $11 a, 11 b, N H(1)$ & $9,11,12,16$ \\
\hline $11 a$ & $2.82, \mathrm{~m}$ & $37.5, \mathrm{CH}_{2}$ & $10,11 b$ & 10,12 \\
\hline $11 b$ & $2.66, \mathrm{~m}$ & & $10,11 a$ & 10,12 \\
\hline 12 & & 128.0, qC & & \\
\hline 13 & $7.00, d(8.4)$ & $130.0, \mathrm{CH}$ & 14 & $11,13,14,15$ \\
\hline 14 & $6.60, d(8.4)$ & $114.9, \mathrm{CH}$ & 13 & $13,14,15$ \\
\hline 15 & & $155.9, q C$ & & \\
\hline 16 & & 164.6, qC & & \\
\hline 17 & $5.93, d(15.5)$ & $124.4, \mathrm{CH}$ & 18,19 & 16 \\
\hline 18 & $6.50, \mathrm{dt}(15.1,7.1)$ & $142.7, \mathrm{CH}$ & 17,19 & $16,17,19$ \\
\hline 19 & $2.07, \mathrm{~m}$ & $31.2, \mathrm{CH}_{2}$ & 18,20 & $17,18,20,21$ \\
\hline 20 & $1.35, \mathrm{~m}$ & $27.5, \mathrm{CH}_{2}$ & 19 & $18,20,21$ \\
\hline 21 & $1.26, \mathrm{~m}$ & $30.8, \mathrm{CH}_{2}$ & & $20,22,23$ \\
\hline 22 & $1.23, \mathrm{~m}$ & $21.9, \mathrm{CH}_{2}$ & 23 & $20,21,23$ \\
\hline 23 & $0.85, \mathrm{t}(6.9)$ & $13.9, \mathrm{CH}_{3}$ & 22 & 21,22 \\
\hline $\mathrm{NH}(3)$ & 10.02 , br. S & & 7 & \\
\hline $\mathrm{NH}(2)$ & $8.21, d(8.3)$ & & 4 & 9 \\
\hline $\mathrm{NH}(1)$ & $8.15, d(8.3)$ & & 10 & $10,11,16$ \\
\hline
\end{tabular}

${ }^{a} 600 \mathrm{MHz}$ for ${ }^{1} \mathrm{H}$ NMR, COSY, HSQC and HMBC; $150 \mathrm{MHz}$ for ${ }^{13} \mathrm{C}$ NMR ; ${ }^{\mathrm{b}}$ numbers of attached protons were determined by $\mathrm{COSY}^{\mathrm{d}}$ and $\mathrm{HMBC}, \mathrm{HSQC}$. 
Table S7. NMR Table of (S,E)-7-guanidino-4-((R)-3-(4-hydroxyphenyl)-2-((E)-oct-2enamido)propanamido)hept-2-enoic acid (Barnesin-L-Arginine-D-Tyrosine, 6$)$ in $d_{6}$-DMSO at $26^{\circ} \mathrm{C}$

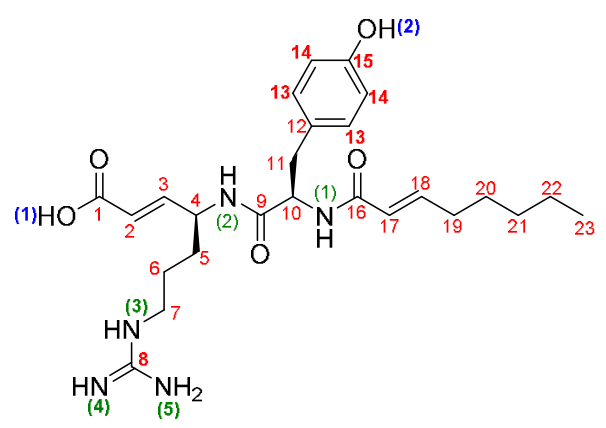

\begin{tabular}{|c|c|c|c|c|}
\hline position & $\delta_{\mathrm{H}}$, mult. $(\mathrm{J}$ in $\mathrm{Hz})$ & $\delta_{c}$, type $^{b}$ & COSY & HMBC \\
\hline \multicolumn{5}{|l|}{1} \\
\hline 2 & $5.70, d(15.8)$ & $129.2, \mathrm{CH}$ & 3 & 4 \\
\hline 3 & $6.36, \mathrm{dd}(15.8,5.2)$ & $140.8, \mathrm{CH}$ & 2,4 & 1,4 \\
\hline 4 & $4.28, \mathrm{~m}$ & $49.2, \mathrm{CH}$ & $3,6, N H(2)$ & \\
\hline $5 a$ & $1.58, \mathrm{~m}$ & $29.1, \mathrm{CH}_{2}$ & $5 b, 6$ & \\
\hline $5 b$ & $1.45, \mathrm{~m}$ & & $5 a, 6$ & \\
\hline 6 & $1.29, \mathrm{~m}$ & $22.5, \mathrm{CH}_{2}$ & $5 a, 5 b, 7$ & 5,7 \\
\hline 7 & $2.97, \mathrm{~m}$ & $40.4^{\mathrm{c}}, \mathrm{CH}_{2}$ & 6 & \\
\hline \multicolumn{5}{|l|}{8} \\
\hline 9 & & $171.2, \mathrm{qC}$ & & \\
\hline 10 & $4.52, \mathrm{~m}$ & $55.0, \mathrm{CH}$ & $11 a, 11 b, N H(1)$ & \\
\hline $11 a$ & $2.82, \mathrm{~m}$ & $38.0, \mathrm{CH}_{2}$ & $10,11 b$ & 12,13 \\
\hline $11 b$ & $2.66, \mathrm{~m}$ & & $10,11 a$ & 12,13 \\
\hline 12 & & 128.3, qC & & \\
\hline 13 & $6.99, d(8.3)$ & $130.5, \mathrm{CH}$ & 14 & $11,13,15$ \\
\hline 14 & $6.60, d(8.5)$ & $115.4, \mathrm{CH}$ & 13 & $12,14,15$ \\
\hline 15 & & $156.3, q C$ & & \\
\hline 16 & & 165.0, qC & & \\
\hline 17 & $5.94, d(15.8)$ & $124.8, \mathrm{CH}$ & 18,19 & 16,19 \\
\hline 18 & $6.53, \mathrm{dt}(15.0,7.2)$ & $143.1, \mathrm{CH}$ & 17,19 & $16,19,20$ \\
\hline 19 & $2.07, \mathrm{~m}$ & $31.6, \mathrm{CH}_{2}$ & 18,20 & $17,18,20,21$ \\
\hline 20 & $1.35, \mathrm{~m}$ & $27.9, \mathrm{CH}_{2}$ & 19 & $18,21,22$ \\
\hline 21 & $1.24, \mathrm{~m}$ & $31.3, \mathrm{CH}_{2}$ & & $20,22,23$ \\
\hline 22 & $1.23, \mathrm{~m}$ & $22.3, \mathrm{CH}_{2}$ & 23 & $20,21,23$ \\
\hline 23 & $0.85, \mathrm{t}(6.7)$ & $14.3, \mathrm{CH}_{3}$ & 22 & 21,22 \\
\hline $\mathrm{NH}(3)$ & 9.99, br. S & & & \\
\hline $\mathrm{NH}(2)$ & $8.21, \mathrm{~d}(8.1)$ & & 4 & 9 \\
\hline $\mathrm{NH}(1)$ & $8.15, d(8.1)$ & & 10 & 16 \\
\hline
\end{tabular}

${ }^{a} 600 \mathrm{MHz}$ for ${ }^{1} \mathrm{H}$ NMR, COSY, HSQC and HMBC; $150 \mathrm{MHz}$ for ${ }^{13} \mathrm{C} \mathrm{NMR} \mathrm{;}{ }^{\mathrm{b}}$ numbers of attached protons were determined by COSYd and $\mathrm{HMBC}, \mathrm{HSQC}$. 
Table S8. NMR table of (S,E)-7-guanidino-4-((S)-3-(4-hydroxyphenyl)-2stearamidopropanamido)hept-2-enoic acid (Barnesin-L-Arginine-L-Tyrosine-stearic acid, 7 ) in $d_{\sigma^{-}}$ DMSO at $26^{\circ} \mathrm{C}$.

\begin{tabular}{|c|c|c|c|c|}
\hline position & $\delta_{\mathrm{H}}$, mult. $(\mathrm{J}$ in $\mathrm{Hz})$ & $\delta_{c}$, type $^{b}$ & COSY & $\mathrm{HMBC}$ \\
\hline 1 & & 169.8, qC & & \\
\hline 2 & $5.72, \mathrm{~d}(15.4)$ & $125.4, \mathrm{CH}$ & 3 & 1,4 \\
\hline 3 & $6.50, \mathrm{dd}(15.4,5.0)$ & $143.6, \mathrm{CH}$ & 2 & $1,2,4,5$ \\
\hline 4 & $4.36, \mathrm{~m}$ & $48.8, \mathrm{CH}$ & $5, N H(2)$ & 5 \\
\hline $5 a$ & $1.62, \mathrm{~m}$ & $30.7, \mathrm{CH}_{2}$ & $5 b, 6$ & \\
\hline $5 b$ & $1.44, \mathrm{~m}$ & & $5 a, 6$ & 6 \\
\hline 6 & $1.44, \mathrm{~m}$ & $24.8, \mathrm{CH}_{2}$ & $5 a, 5 b, 7$ & $4,5,7$ \\
\hline 7 & $3.05, \mathrm{~m}$ & $40.1, \mathrm{CH}_{2}$ & 6 & $5,6,8$ \\
\hline 8 & & 157.3, qC & & \\
\hline 9 & & 171.2, qC & & \\
\hline 10 & $4.40, \mathrm{~m}$ & $54.4, \mathrm{CH}$ & $11 a, 11 b, N H(1)$ & $9,11,12$ \\
\hline $11 a$ & $2.84, \mathrm{~m}$ & $37.2, \mathrm{CH}_{2}$ & $10,11 b$ & $9,10,12$ \\
\hline $11 b$ & $2.61, \mathrm{~m}$ & & $10,11 a$ & $9,10,12$ \\
\hline 12 & & $127.9, \mathrm{qC}$ & & \\
\hline 13 & $6.98, d(8.3)$ & $130.0, \mathrm{CH}$ & 14 & $11,14,15$ \\
\hline 14 & $6.60, d(8.3)$ & $114.8, \mathrm{CH}$ & 13 & 12,15 \\
\hline 15 & & $155.8, \mathrm{qC}$ & & \\
\hline 16 & & 172.0, qC & & \\
\hline 17 & 1.99, m & $35.2, \mathrm{CH}_{2}$ & 18 & $16,18,19$ \\
\hline 18 & $1.34, \mathrm{~m}$ & $25.2, \mathrm{CH}_{2}$ & 19 & 16,17 \\
\hline 19 & $1.08, \mathrm{~m}$ & $28.8, \mathrm{~m}, \mathrm{CH}_{2}$ & 20,21 & 17,18 \\
\hline 20 & $1.17, \mathrm{~m}$ & $28.8, \mathrm{~m}, \mathrm{CH}_{2}$ & 19,21 & \\
\hline 21 & $1.17, \mathrm{~m}$ & $28.8, \mathrm{~m}, \mathrm{CH}_{2}$ & 19,21 & \\
\hline 22 & $1.23, \mathrm{~m}$ & $28.8, \mathrm{~m}, \mathrm{CH}_{2}$ & 21,23 & \\
\hline 23 & $1.23, \mathrm{~m}$ & $28.8, \mathrm{~m}, \mathrm{CH}_{2}$ & 22,24 & \\
\hline 24 & $1.23, \mathrm{~m}$ & $28.8, \mathrm{~m}, \mathrm{CH}_{2}$ & 23,25 & \\
\hline 25 & $1.23, \mathrm{~m}$ & $28.8, \mathrm{~m}, \mathrm{CH}_{2}$ & 24,26 & \\
\hline 26 & $1.23, \mathrm{~m}$ & $28.8, \mathrm{~m}, \mathrm{CH}_{2}$ & 25,27 & \\
\hline 27 & $1.23, \mathrm{~m}$ & $28.8, \mathrm{~m}, \mathrm{CH}_{2}$ & 26,28 & \\
\hline 28 & $1.23, \mathrm{~m}$ & $28.8, \mathrm{~m}, \mathrm{CH}_{2}$ & 27,29 & \\
\hline 29 & $1.23, \mathrm{~m}$ & $28.8, \mathrm{~m}, \mathrm{CH}_{2}$ & 28,30 & \\
\hline 30 & $1.23, \mathrm{~m}$ & $28.8, \mathrm{~m}, \mathrm{CH}_{2}$ & 29,31 & \\
\hline 31 & $1.23, \mathrm{~m}$ & $31.3, \mathrm{CH}_{2}$ & 30,32 & \\
\hline 32 & $1.23, \mathrm{~m}$ & $22.1, \mathrm{CH}_{2}$ & 31,33 & \\
\hline 33 & $0.85, \mathrm{t}(6.5)$ & $13.9, \mathrm{CH}_{3}$ & $22-32$ & 31,32 \\
\hline $\mathrm{NH}(3)$ & 9.36, br. $S$ & & 7 & \\
\hline $\mathrm{NH}(2)$ & $8.30, d(8.3)$ & & 4 & 4, 9 \\
\hline $\mathrm{NH}(1)$ & $7.91, d(8.3)$ & & 10 & $10,11,16$ \\
\hline
\end{tabular}


Table S9. NMR table of (S,E)-7-guanidino-4-((S)-3-(4-hydroxyphenyl)-2-

octanamidopropanamido)hept-2-enoic acid (17,18-Dihydrobarnesin, 8) in $d_{6}$-DMSO at $26^{\circ} \mathrm{C}$

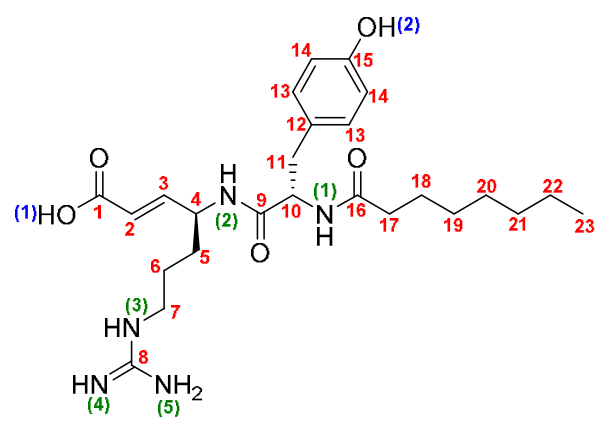

\begin{tabular}{|c|c|c|c|c|}
\hline position & $\delta_{\mathrm{H}}$, mult. $(\mathrm{J}$ in $\mathrm{Hz})$ & $\delta_{c}$, type $^{b}$ & COSY & HMBC \\
\hline 1 & & 171.6, qC & & \\
\hline 2 & $5.73, \mathrm{~d}(15.4)$ & $128.7, \mathrm{CH}$ & 3,4 & 1,4 \\
\hline 3 & $6.43, \mathrm{dd}(15.4,4.9)$ & $142.5, \mathrm{CH}$ & 2,4 & 1,4 \\
\hline 4 & $4.34, \mathrm{~m}$ & $49.3, \mathrm{CH}$ & $3,5, N H(2)$ & \\
\hline $5 a$ & $1.66, \mathrm{~m}$ & $31.2, \mathrm{CH}_{2}$ & $4,5 b, 6$ & \\
\hline $5 b$ & $1.38, \mathrm{~m}$ & & $4,5 a$ & \\
\hline 6 & $1.45, \mathrm{~m}$ & $25.2, \mathrm{CH}_{2}$ & $5 a, 5 b, 7$ & $4,5,7$ \\
\hline 7 & $3.05, \mathrm{~m}$ & $40.5, \mathrm{CH}_{2}$ & $6, \mathrm{NH}(3)$ & $5,6,8$ \\
\hline 8 & & 158.0, qC & & \\
\hline 9 & & $171.4, q C$ & & \\
\hline 10 & $4.42, \mathrm{~m}$ & $54.9, \mathrm{CH}$ & $11 a, 11 b, N H(1)$ & 9,11 \\
\hline $11 a$ & $2.85, \mathrm{~m}$ & $37.8, \mathrm{CH}_{2}$ & $10,11 b$ & 10,12 \\
\hline $11 b$ & $2.59, \mathrm{~m}$ & & $10,11 a$ & 10,12 \\
\hline 12 & & $127.9, \mathrm{qC}$ & & \\
\hline 13 & $6.98, d(8.4)$ & $130.6, \mathrm{CH}$ & 14 & $11,12,14,15$ \\
\hline 14 & $6.61, d(8.4)$ & $115.4, \mathrm{CH}$ & 13 & $12,14,15$ \\
\hline 15 & & 156.2, qC & & \\
\hline 16 & & 172.6, qC & & \\
\hline 17 & $1.99, \mathrm{~m}$ & $35.9, \mathrm{CH}_{2}$ & 18 & $16,18,19$ \\
\hline 18 & $1.35, \mathrm{~m}$ & $25.8, \mathrm{CH}_{2}$ & 17,19 & 19,20 \\
\hline 19 & $1.08, \mathrm{~m}$ & 29.1, $\mathrm{CH}_{2}$ & 18 & 20,21 \\
\hline 20 & $1.18, \mathrm{~m}$ & 29.1, $\mathrm{CH}_{2}$ & 19 & \\
\hline 21 & $1.18, \mathrm{~m}$ & $31.7, \mathrm{CH}_{2}$ & & $20,21,22,23$ \\
\hline 22 & $1.24, \mathrm{~m}$ & 22.7, $\mathrm{CH}_{2}$ & 21,23 & $20,21,23$ \\
\hline 23 & $0.85, \mathrm{t}(7.1)$ & $14.4, \mathrm{CH}_{3}$ & 22 & 21,22 \\
\hline $\mathrm{NH}(3)$ & 9.81, br. s & & 7 & \\
\hline $\mathrm{NH}(2)$ & $8.37, d(8.2)$ & & 4 & 9 \\
\hline $\mathrm{NH}(1)$ & $7.92, d(8.7)$ & & 10 & $10,11,16$ \\
\hline
\end{tabular}

${ }^{\mathrm{a}} 600 \mathrm{MHz}$ for ${ }^{1} \mathrm{H}$ NMR, COSY, HSQC and $\mathrm{HMBC} ; 150 \mathrm{MHz}$ for ${ }^{13} \mathrm{C} \mathrm{NMR} ;{ }^{\mathrm{b}}$ numbers of attached protons were determined by $\mathrm{COSY}^{\mathrm{d}}$ and $\mathrm{HMBC}, \mathrm{HSQC}$. 
Table S10. NMR table of $(S, E)-4-((S)-2-((E)$-but-2-enamido)-3-(4-hydroxyphenyl)propanamido)-7guanidinohept-2-enoic acid (Barnesin-trans-2-butenoic acid, 9) in $d_{6}$-DMSO at $26^{\circ} \mathrm{C}$

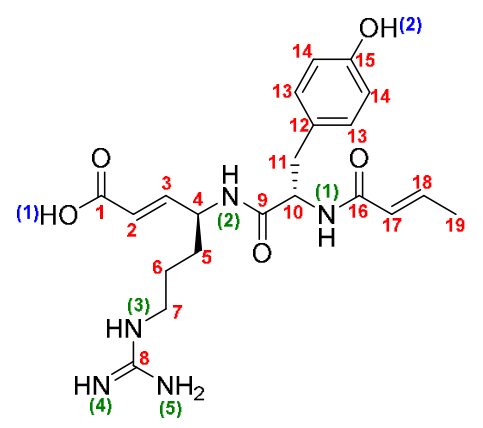

\begin{tabular}{|c|c|c|c|c|}
\hline position & $\delta_{\mathrm{H}}$, mult. $(\mathrm{J}$ in Hz$)$ & $\delta_{c}$, type & $\cos Y$ & HMBC \\
\hline 1 & & $171.4, q C$ & & \\
\hline 2 & $5.70, d(15.5)$ & $127.9, \mathrm{CH}$ & 3 & 1,4 \\
\hline 3 & $6.39, \mathrm{dd}(15.5,5.6)$ & $140.8, \mathrm{CH}$ & 2,4 & $1,4,5$ \\
\hline 4 & $4.29, \mathrm{~m}$ & $48.7, \mathrm{CH}$ & $3,5, N H(2)$ & \\
\hline $5 a$ & $1.30^{\mathrm{d}}, \mathrm{m}$ & $30.9, \mathrm{CH}_{2}$ & $4,5 b, 6$ & \\
\hline $5 b$ & $1.61, \mathrm{~m}$ & & $4,5 a$ & 6 \\
\hline 6 & $1.31, \mathrm{~m}$ & 24.7, $\mathrm{CH}_{2}$ & $5 a, 5 b, 7$ & 4,5 \\
\hline 7 & $2.98, \mathrm{~m}$ & $40.1^{c}, \mathrm{CH}_{2}$ & 6, $\mathrm{NH}(3)$ & $5,6,8$ \\
\hline 8 & & $157.5, \mathrm{qC}$ & & \\
\hline 9 & & 170.6, qC & & \\
\hline 10 & $4.52, \mathrm{~m}$ & $54.6, \mathrm{CH}$ & 11a, 11b, $N H(1)$ & $9,11,12,16$ \\
\hline $11 a$ & $2.82, \mathrm{~m}$ & $37.5, \mathrm{CH}_{2}$ & $10,11 b$ & $9,10,12,13$ \\
\hline $11 b$ & $2.66, \mathrm{~m}$ & & $10,11 a$ & $9,10,12,13$ \\
\hline 12 & & $128.3, q C$ & & \\
\hline 13 & $7.00, d(8.3)$ & $129.9, \mathrm{CH}$ & 14 & $11,13,14,15$ \\
\hline 14 & $6.62, d(8.3)$ & $114.8, \mathrm{CH}$ & 13 & $13,14,15$ \\
\hline 15 & & $155.8, \mathrm{qC}$ & & \\
\hline 16 & & $164.5, \mathrm{qC}$ & & \\
\hline 17 & $5.95, d(15.4)$ & $125.7, \mathrm{CH}$ & 18,19 & 16,19 \\
\hline 18 & $6.52, \mathrm{dt}(15.1,6.8)$ & $137.9, \mathrm{CH}$ & 17,19 & $16,17,19$ \\
\hline 19 & $1.73, \mathrm{~d}(5.7)$ & 17.36, $\mathrm{CH}_{2}$ & 18,20 & $16,17,18$ \\
\hline $\mathrm{NH}(3)$ & 10.08 , br. S & & 7 & \\
\hline $\mathrm{NH}(2)$ & $8.19, d(8.4)$ & & 4 & 4,9 \\
\hline $\mathrm{NH}(1)$ & $8.12, d(9.0)$ & & 10 & $10,11,16$ \\
\hline
\end{tabular}

${ }^{\mathrm{a}} 600 \mathrm{MHz}$ for ${ }^{1} \mathrm{H}$ NMR, COSY, HSQC and HMBC; $150 \mathrm{MHz}$ for ${ }^{13} \mathrm{C} \mathrm{NMR} \mathrm{;}{ }^{\mathrm{b}}$ numbers of attached protons were determined by COSYd and $\mathrm{HMBC}, \mathrm{HSQC}$. 
Table S11. NMR table of $(S, E)$-4-((S)-2-acetamido-3-(4-hydroxyphenyl)propanamido)-7guanidinohept-2-enoic acid (Acylderivative, 10) in $d_{6}$-DMSO at $26^{\circ} \mathrm{C}$

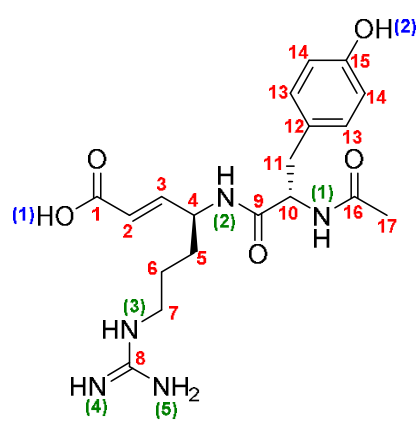

\begin{tabular}{|c|c|c|c|c|}
\hline position & $\delta_{\mathrm{H}}$, mult. $(\mathrm{J}$ in Hz$)$ & $\delta_{c}$, type $^{b}$ & $\cos Y$ & HMBC \\
\hline 1 & & 169.7, qC & & \\
\hline 2 & $5.73, \mathrm{~m}$ & $125.3, \mathrm{CH}$ & 3 & 1,4 \\
\hline 3 & $6.50, \mathrm{~m}$ & $143.8, \mathrm{CH}$ & 2,4 & $1,2,4,5$ \\
\hline 4 & $4.38, \mathrm{~m}$ & $48.8, \mathrm{CH}$ & $3,5 a, 5 b, N H(2)$ & \\
\hline $5 a$ & $1.44, \mathrm{~m}$ & $31.00, \mathrm{CH}_{2}$ & $4,5 b, 6$ & \\
\hline $5 b$ & $1.61, \mathrm{~m}$ & & $4,5 a, 6$ & \\
\hline 6 & $1.44 \mathrm{~m}$ & 25.1, $\mathrm{CH}_{2}$ & $5 a, 5 b, 7$ & \\
\hline 7 & $3.02, \mathrm{~m}$ & $40.6, \mathrm{CH}_{2}$ & 6, NH(3) & 5,8 \\
\hline 8 & & $157.5, \mathrm{qC}$ & & \\
\hline 9 & & $171.3, \mathrm{qC}$ & & \\
\hline 10 & $4.38, \mathrm{~m}$ & $54.6, \mathrm{CH}$ & 11a, 11b, NH(1) & 9,11 \\
\hline 11a & $2.83, \mathrm{~m}$ & 37.3, $\mathrm{CH}_{2}$ & $10,11 b$ & $9,10,12,13$ \\
\hline $11 b$ & $2.62, \mathrm{~m}$ & & $10,11 a$ & $9,10,12,13$ \\
\hline 12 & & $127.9, \mathrm{qC}$ & & \\
\hline 13 & $7.00, \mathrm{~m}$ & $130.0, \mathrm{CH}$ & 14 & $11,14,15$ \\
\hline 14 & $6.63, \mathrm{~m}$ & 114.9, CH & 13 & $12,13,15$ \\
\hline 15 & & $156.0, q C$ & & \\
\hline 16 & & $169.0, q C$ & & \\
\hline 17 & $1.75, \mathrm{~m}$ & $22.8, \mathrm{CH}_{3}$ & & 16 \\
\hline $\mathrm{NH}(3)$ & 9.26 , br. S & & 7 & \\
\hline $\mathrm{NH}(2)$ & $8.30, d(8.18)$ & & 4 & 4,9 \\
\hline $\mathrm{NH}(1)$ & $8.07, d(8.6)$ & & 10 & $10,11,16$ \\
\hline
\end{tabular}

${ }^{\mathrm{a}} 600 \mathrm{MHz}$ for ${ }^{1} \mathrm{H} \mathrm{NMR}, \mathrm{COSY}, \mathrm{HSQC}$ and $\mathrm{HMBC} ; 150 \mathrm{MHz}$ for ${ }^{13} \mathrm{C} \mathrm{NMR}$; ${ }^{\mathrm{b}}$ numbers of attached protons were determined by COSYd and HMBC, HSQCc. 
Table S12. NMR table of (S)-7-guanidino-4-((S)-3-(4-hydroxyphenyl)-2octanamidopropanamido)heptanoic acid $(2,3,17,18$-Tetrahydro Barnesin, 11$)$ in $d_{\sigma}$-DMSO at $26^{\circ} \mathrm{C}$

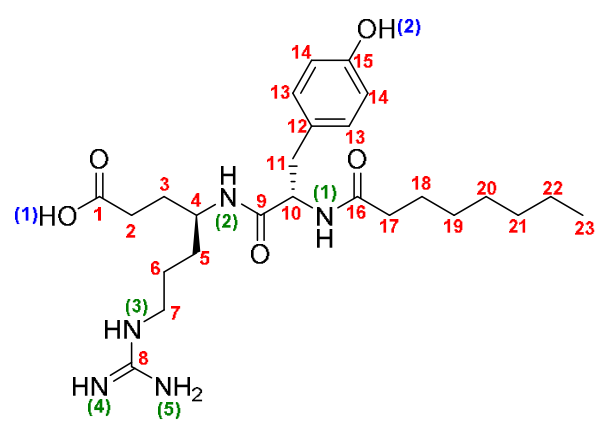

\begin{tabular}{|c|c|c|c|c|}
\hline position & $\delta_{\mathrm{H}}$, mult. $(\mathrm{J}$ in $\mathrm{Hz})$ & $\delta_{c}$, type $^{b}$ & COSY & $\mathrm{HMBC}$ \\
\hline 1 & & $176.9, q C$ & & \\
\hline 2 & 1.95, m & $33.1, \mathrm{CH}$ & 3 & 1,4 \\
\hline $3 a$ & $1.65, \mathrm{~m}$ & $31.3, \mathrm{CH}$ & 2,4 & $1,2,4$ \\
\hline $3 b$ & $1.48, \mathrm{~m}$ & & & \\
\hline 4 & $4.64, \mathrm{~m}$ & $48.0, \mathrm{CH}$ & $3,5, N H(2)$ & \\
\hline $5 a$ & $1.33, \mathrm{~m}$ & $30.8, \mathrm{CH}_{2}$ & 4, 5b, 6 & \\
\hline $5 b$ & $1.49, \mathrm{~m}$ & & $4,5 a$ & 6 \\
\hline 6 & $1.41, \mathrm{~m}$ & 24.9, $\mathrm{CH}_{2}$ & $5 a, 5 b, 7$ & $4,5,7$ \\
\hline 7 & $3.01, \mathrm{~m}$ & $40.3, \mathrm{CH}_{2}$ & 6 & 6,8 \\
\hline 8 & & 157.5, qC & & \\
\hline 9 & & $171.2, \mathrm{qC}$ & & \\
\hline 10 & $4.35, \mathrm{~m}$ & $54.4, \mathrm{CH}$ & $11 a, 11 b, N H(1)$ & $9,11,12,16$ \\
\hline $11 a$ & $2.81, \mathrm{~m}$ & $37.2, \mathrm{CH}_{2}$ & $10,11 b$ & 10,12 \\
\hline $11 b$ & $2.62, \mathrm{~m}$ & & $10,11 a$ & 10,12 \\
\hline 12 & & 128.0, qC & & \\
\hline 13 & $6.99, d(8.3)$ & $129.9, \mathrm{CH}$ & 14 & $11,13,14,15$ \\
\hline 14 & $6.61, d(8.3)$ & 114.7, $\mathrm{CH}$ & 13 & $13,14,15$ \\
\hline 15 & & $155.8, q C$ & & \\
\hline 16 & & 172.0, qC & & \\
\hline 17 & $2.01, \mathrm{~m}$ & $35.2, \mathrm{CH}$ & 18,19 & 16 \\
\hline 18 & $1.35, \mathrm{~m}$ & $25.2, \mathrm{CH}$ & 17,19 & $16,17,19$ \\
\hline 19 & $1.09, \mathrm{~m}$ & 28.4, $\mathrm{CH}_{2}$ & 18,20 & $17,18,20,21$ \\
\hline 20 & $1.17, \mathrm{~m}$ & 28.4, $\mathrm{CH}_{2}$ & 19 & $18,20,21$ \\
\hline 21 & $1.17, \mathrm{~m}$ & $31.1, \mathrm{CH}_{2}$ & & $20,22,23$ \\
\hline 22 & $1.23, \mathrm{~m}$ & 22.1, $\mathrm{CH}_{2}$ & 23 & $20,21,23$ \\
\hline 23 & $0.84, \mathrm{t}(7.06)$ & $13.9, \mathrm{CH}_{3}$ & 22 & 21,22 \\
\hline $\mathrm{NH}(3)$ & 9.29, br. S & & 7 & \\
\hline $\mathrm{NH}(2)$ & $7.90, d(8.5)$ & & 4 & 9 \\
\hline $\mathrm{NH}(1)$ & $7.86, d(8.5)$ & & 10 & $10,11,16$ \\
\hline
\end{tabular}

${ }^{a} 600 \mathrm{MHz}$ for ${ }^{1} \mathrm{H}$ NMR, COSY, HSQC and $\mathrm{HMBC} ; 150 \mathrm{MHz}$ for ${ }^{13} \mathrm{C}$ NMR ; ${ }^{\mathrm{b}}$ numbers of attached protons were determined by COSYd and HMBC, HSQCc. 
Table S13. NMR table of (S,E)-7-guanidino-4-((S)-2-((E)-oct-2-enamido)-3-phenylpropanamido)hept2-enoic acid (Barnesin-L-Phenylalanine, 12) in $d_{6}$-DMSO at $26^{\circ} \mathrm{C}$

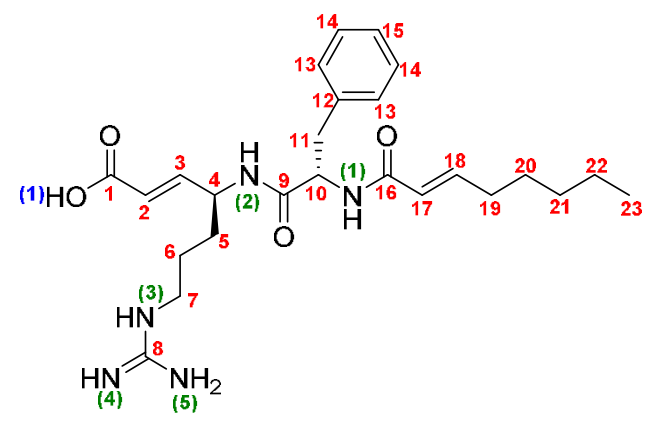

\begin{tabular}{|c|c|c|c|c|}
\hline position & $\delta_{\mathrm{H}}$, mult. $(\mathrm{J}$ in $\mathrm{Hz})$ & $\delta_{c}$, type $^{b}$ & COSY & HMBC \\
\hline 1 & & 170.6, qC & & \\
\hline 2 & $5.72, d(15.4)$ & $126.2, \mathrm{CH}$ & 3 & 1,4 \\
\hline 3 & $6.49, \mathrm{~m}$ & $142.3, \mathrm{CH}$ & 2,4 & $1,2,4$ \\
\hline 4 & $4.36, \mathrm{~m}$ & $48.8, \mathrm{CH}$ & $3,5, N H(2)$ & $5,6,9$ \\
\hline $5 a$ & $1.39, \mathrm{~m}$ & $30.7, \mathrm{CH}_{2}$ & $4,5 b, 6$ & $4,6,7$ \\
\hline $5 b$ & $1.67, \mathrm{~m}$ & & 4, 5a & $4,6,7$ \\
\hline 6 & $1.46, \mathrm{~m}$ & $24.9, \mathrm{CH}_{2}$ & $5 a, 5 b, 7$ & $4,5,7$ \\
\hline 7 & $3.07, \mathrm{~m}$ & $40.1^{\mathrm{c}}, \mathrm{CH}_{2}$ & 6 & $5,6,8$ \\
\hline 8 & & $157.3, \mathrm{qC}$ & & \\
\hline 9 & & $170.9, q C$ & & \\
\hline 10 & $4.56, \mathrm{~m}$ & $54.3, \mathrm{CH}$ & $11 a, 11 b, N H(1)$ & $9,11,12,16$ \\
\hline $11 a$ & $2.98, \mathrm{~m}$ & $38.2, \mathrm{CH}_{2}$ & $10,11 b$ & $9,10,12,13,14$ \\
\hline $11 b$ & $2.71, \mathrm{~m}$ & & $10,11 a$ & $9,10,12,13,14$ \\
\hline 12 & & 138.0, qC & & \\
\hline 13 & $7.23, \mathrm{~m}$ & $129.1, \mathrm{CH}$ & & $11,13,14,15$ \\
\hline 14 & $7.23, \mathrm{~m}$ & $128.0, \mathrm{CH}$ & 15 & $13,14,15$ \\
\hline 15 & $7.16, \mathrm{~m}$ & 129.7, qC & 14 & 13,14 \\
\hline 16 & & 164.7, qC & & \\
\hline 17 & $5.89, \mathrm{~d}(15.5)$ & $124.3, \mathrm{CH}$ & 18 & 16,19 \\
\hline 18 & 6.49, m & $142.8, \mathrm{CH}$ & 17,19 & $16,17,19$ \\
\hline 19 & $2.06, q(7.3,14.2)$ & $31.2, \mathrm{CH}_{2}$ & 18,20 & $17,18,20,21$ \\
\hline 20 & $1.35, \mathrm{~m}$ & $27.5, \mathrm{CH}_{2}$ & 19 & $18,20,21$ \\
\hline 21 & $1.27, \mathrm{~m}$ & $30.8, \mathrm{CH}_{2}$ & & $20,22,23$ \\
\hline 22 & $1.23, \mathrm{~m}$ & $21.9, \mathrm{CH}_{2}$ & 23 & $20,21,23$ \\
\hline 23 & $0.85, \mathrm{t}(7.0)$ & $13.9, \mathrm{CH}_{3}$ & 22 & 21,22 \\
\hline $\mathrm{NH}(3)$ & 9.79, br. S & & 7 & \\
\hline $\mathrm{NH}(2)$ & $8.47, d(8.3)$ & & 4 & 4,9 \\
\hline $\mathrm{NH}(1)$ & $8.13, d(8.5)$ & & 10 & $10,11,16$ \\
\hline
\end{tabular}

${ }^{a} 600 \mathrm{MHz}$ for ${ }^{1} \mathrm{H}$ NMR, COSY, HSQC and HMBC; $150 \mathrm{MHz}$ for ${ }^{13} \mathrm{C} \mathrm{NMR} \mathrm{;}{ }^{\mathrm{b}}$ numbers of attached protons were determined by COSYd and $\mathrm{HMBC}, \mathrm{HSQC}$. 
Table S14. NMR table of methyl (S,E)-8-amino-4-((S)-3-(4-hydroxyphenyl)-2-((E)-oct-2enamido)propanamido)oct-2-enoate (Barnesin-L-Lysin-OMe, 13) in $d_{6}$-DMSO at $26^{\circ} \mathrm{C}$

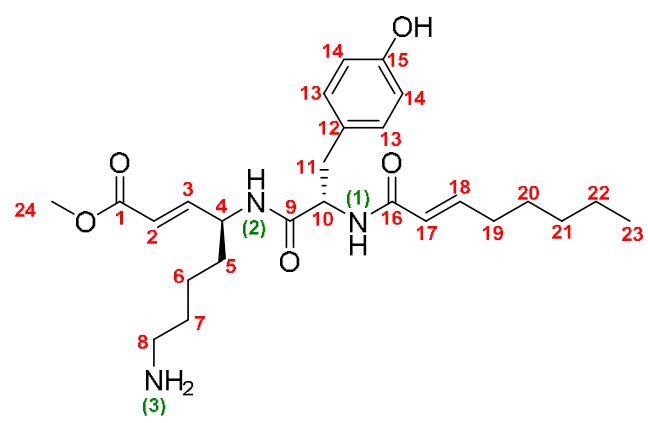

\begin{tabular}{|c|c|c|c|c|}
\hline position & $\delta_{\mathrm{H}}$, mult. $(J$ in $\mathrm{Hz})$ & $\delta_{c}$, type $^{b}$ & COSY & HMBC \\
\hline 1 & & 166.1, qC & & \\
\hline 2 & $5.73, d(15.4)$ & $119.5, \mathrm{CH}$ & 3 & 1,3 \\
\hline 3 & $6.76, \mathrm{dd}(5.2,15.7)$ & $149.1, \mathrm{CH}$ & 2,4 & $1,2,4,5$ \\
\hline 4 & $4.39, \mathrm{~m}^{\mathrm{c}}$ & $49.1, \mathrm{CH}$ & $3,5 a, 5 b, \mathrm{NH}(2)$ & $2,3,5$ \\
\hline $5 a$ & $1.57, \mathrm{~m}^{\mathrm{c}}$ & $32.6, \mathrm{CH}_{2}$ & 4 & $3,4,6$ \\
\hline $5 b$ & $1.42, \mathrm{~m}^{\mathrm{c}}$ & & 4 & $3,4,6$ \\
\hline 6 & $1.27, \mathrm{~m}^{\mathrm{c}}$ & $22.2, \mathrm{CH}_{2}$ & & \\
\hline 7 & $1.51, \mathrm{~m}$ & 26.6, $\mathrm{CH}_{2}$ & 8 & 5,6 \\
\hline 8 & $2.75, \mathrm{~m}$ & $38.6, \mathrm{CH}_{2}$ & $7, \mathrm{NH}(3)$ & 7 \\
\hline 9 & & 171.1, qC & & \\
\hline 10 & $4.45, \mathrm{~m}$ & $54.7, \mathrm{CH}$ & $11 a, 11 b, N H(1)$ & 11,12 \\
\hline $11 a$ & $2.83, \mathrm{dd}(5.4,13.9)$ & $37.1, \mathrm{CH}_{2}$ & $10,11 b$ & $9,10,12$ \\
\hline $11 b$ & $2.68, \mathrm{dd}(9.2,13.4)$ & & $10,11 a$ & $9,10,12$ \\
\hline 12 & & 127.6, qC & & \\
\hline 13 & $7.01, d(8.5)$ & $130.0, \mathrm{CH}$ & 14 & $11,13,14,15$ \\
\hline 14 & $6.62, d(8.5)$ & $114.9, \mathrm{CH}$ & 13 & $12,13,14,15$ \\
\hline 15 & & $155.9, \mathrm{qC}$ & & \\
\hline 16 & & $164.8, \mathrm{qC}$ & & \\
\hline 17 & $5.95, d(14.4)^{c}$ & $124.1, \mathrm{CH}$ & 18 & 16,19 \\
\hline 18 & $6.55, \mathrm{dt},(6.8,15.3)$ & $142.9, \mathrm{CH}$ & 17,19 & $16,19,20$ \\
\hline 19 & $2.09, \mathrm{q}(7.0,14.0)$ & $31.2, \mathrm{CH}_{2}$ & 18,20 & $17,18,20,21$ \\
\hline 20 & $1.37, \mathrm{~m}^{\mathrm{c}}$ & $27.4, \mathrm{CH}_{2}$ & 19,21 & 21,22 \\
\hline 21 & $1.27, \mathrm{~m}^{\mathrm{c}}$ & $30.8, \mathrm{CH}_{2}$ & 20 & 22 \\
\hline 22 & $1.27, \mathrm{~m}^{\mathrm{c}}$ & 21.9, $\mathrm{CH}_{2}$ & 23 & $20,21,23$ \\
\hline 23 & $0.86, \mathrm{t}(7.3)$ & $13.9, \mathrm{CH}_{3}$ & 22 & 21,22 \\
\hline 24 & $3.65, \mathrm{~s}$ & $51.4, \mathrm{CH}_{3}$ & & 1 \\
\hline $\mathrm{NH}(1)$ & $8.12, \mathrm{~d}(7.3)$ & & 10 & $10,11,16$ \\
\hline $\mathrm{NH}(2)$ & $8.18, d(8.3)$ & & 4 & 4,9 \\
\hline $\mathrm{NH}_{2}(3)$ & $7.73, \mathrm{~s}$ br. & & & \\
\hline
\end{tabular}


Table S15. NMR table of methyl (S,E)-8-amino-4-((S)-2-((E)-oct-2-enamido)-3phenylpropanamido)oct-2-enoate (Barnesin-L-Lysin-OMe-L-Phenylalanine, 14 ) in $d_{\sigma}$-DMSO at $26^{\circ} \mathrm{C}$

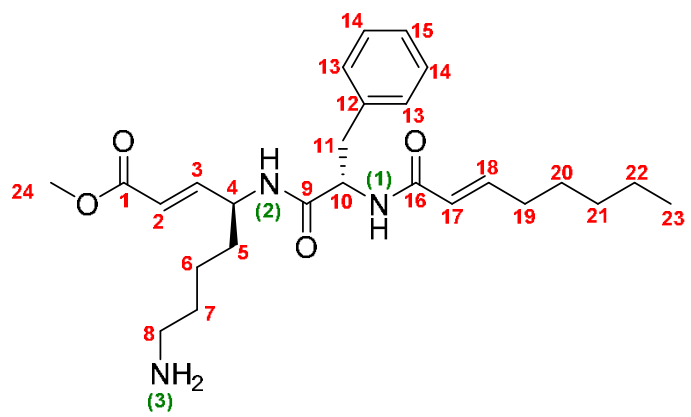

\begin{tabular}{|c|c|c|c|c|}
\hline position & $\delta_{\mathrm{H}}$, mult. ( $J$ in $\mathrm{Hz}$ ) & $\delta_{c}$, type $^{b}$ & cosY & HMBC \\
\hline 1 & & $165.8, q C$ & & \\
\hline 2 & $5.69, \mathrm{~d}(15.4)$ & $119.3, \mathrm{CH}$ & 3 & 1,4 \\
\hline 3 & $6.74, \mathrm{dd}(5.3,15.5)$ & $149.2, \mathrm{CH}$ & 2,4 & $1,4,5$ \\
\hline 4 & $4.38, \mathrm{~m}^{\mathrm{c}}$ & $49.2, \mathrm{CH}$ & $5 a, 5 b, \mathrm{NH}(2)$ & $2,3,5$ \\
\hline $5 a$ & $1.54, \mathrm{~m}^{\mathrm{c}}$ & $33.7, \mathrm{CH}_{2}$ & 4 & 4,6 \\
\hline $5 b$ & $1.45, \mathrm{~m}^{\mathrm{c}}$ & & 4 & 4,6 \\
\hline 6 & $1.25, \mathrm{~m}^{\mathrm{c}}$ & $22.4, \mathrm{CH}_{2}$ & & \\
\hline 7 & $1.45, \mathrm{~m}$ & $28.3, \mathrm{CH}_{2}$ & 8 & 6,8 \\
\hline 8 & $2.66, \mathrm{~m}$ & $39.1, \mathrm{CH}_{2}$ & 7 & 6,7 \\
\hline 9 & & 171.0, qC & & \\
\hline 10 & $4.54, \mathrm{~m}$ & $54.5, \mathrm{CH}$ & $11 a, 11 b, N H(1)$ & $9,11,12$ \\
\hline $11 a$ & $2.95, \mathrm{dd}(5.5,13.6)$ & $37.8, \mathrm{CH}_{2}$ & $10,11 b$ & $9,10,12,13$ \\
\hline $11 b$ & $2.81, \mathrm{dd}(4.2,13.5)$ & & $10,11 a$ & $9,10,12,13$ \\
\hline 12 & & 137.7, qC & & \\
\hline 13 & $7.24, \mathrm{~m}$ & $129.1, \mathrm{CH}$ & & $11,13,14,15$ \\
\hline 14 & $7.24, \mathrm{~m}$ & $128.0, \mathrm{CH}$ & 15 & $12,, 13,14,15$ \\
\hline 15 & 7.17, m & 126.3, qC & 14 & 14 \\
\hline 16 & & $164.8, \mathrm{qC}$ & & \\
\hline 17 & $5.95, d(15.4)^{c}$ & $124.1, \mathrm{CH}$ & 1 & 16,19 \\
\hline 18 & $6.55, \mathrm{~m}$ & $142.9, \mathrm{CH}$ & 17,19 & $16,19,20$ \\
\hline 19 & $2.09, \mathrm{q}(6.9,14.2)$ & $31.2, \mathrm{CH}_{2}$ & 18,20 & $17,18,20,21$ \\
\hline 20 & $1.37, \mathrm{~m}^{\mathrm{c}}$ & 27.4, $\mathrm{CH}_{2}$ & 19,21 & 21,22 \\
\hline 21 & $1.26, \mathrm{~m}^{\mathrm{c}}$ & $30.8, \mathrm{CH}_{2}$ & 20 & 22 \\
\hline 22 & $1.25, \mathrm{~m}^{\mathrm{c}}$ & 21.9, $\mathrm{CH}_{2}$ & 23 & $20,21,23$ \\
\hline 23 & $0.85, \mathrm{t}(6.9)$ & $13.9, \mathrm{CH}_{3}$ & 22 & 21,22 \\
\hline 24 & $3.65, \mathrm{~s}$ & $51.35, \mathrm{CH}_{3}$ & & 1 \\
\hline $\mathrm{NH}(1)$ & $8.36, d(7.8)$ & & 10 & 16 \\
\hline $\mathrm{NH}(2)$ & $8.28, d(7.5)$ & & 4 & 9 \\
\hline $\mathrm{NH}_{2}(3)$ & & & & \\
\hline
\end{tabular}

a $600 \mathrm{MHz}$ for ${ }^{1} \mathrm{H}$ NMR, COSY, $\mathrm{HSQC}$ and $\mathrm{HMBC} ; 150 \mathrm{MHz}$ for ${ }^{13} \mathrm{C} \mathrm{NMR} ;{ }^{\mathrm{b}}$ numbers of attached protons were determined by COSYd and $\mathrm{HMBC}, \mathrm{HSQC}$. 
Table S16. NMR table of $(S, E)$-8-amino-4-((S)-2-((E)-oct-2-enamido)-3-phenylpropanamido)oct-2enoic acid (Barnesin-L-Lysin-L-Phenylalanine, 15) in $d_{\sigma}$-DMSO at $26^{\circ} \mathrm{C}$

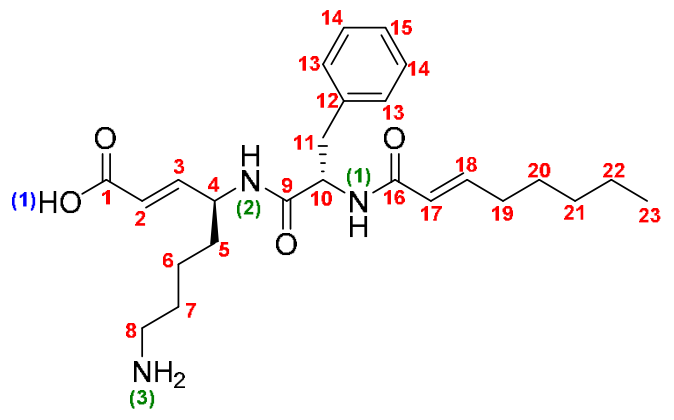

\begin{tabular}{|c|c|c|c|c|}
\hline position & $\delta_{\mathrm{H}}$, mult. $(J$ in $\mathrm{Hz})$ & $\delta_{c}$, type $^{b}$ & COSY & HMBC \\
\hline 1 & & $168.5, q C$ & & \\
\hline 2 & $5.68, d(15.6)$ & $124.7, \mathrm{CH}$ & 3 & 1,4 \\
\hline 3 & $6.50, \mathrm{~m}$ & $144.2, \mathrm{CH}$ & 2,4 & $1,4,5$ \\
\hline 4 & $4.34, \mathrm{~m}^{\mathrm{c}}$ & $49.1, \mathrm{CH}$ & $3,5 a, 5 b, N H(2)$ & $2,3,5$ \\
\hline $5 a$ & $1.50, \mathrm{~m}^{\mathrm{c}}$ & $33.3, \mathrm{CH}_{2}$ & 4 & 4,6 \\
\hline $5 b$ & $1.43, \mathrm{~m}^{\mathrm{c}}$ & & 4 & 4,6 \\
\hline 6 & $1.26, \mathrm{~m}^{\mathrm{c}}$ & $22.2, \mathrm{CH}_{2}$ & & \\
\hline 7 & $1.50, \mathrm{~m}$ & 27.6, $\mathrm{CH}_{2}$ & 8 & 6,8 \\
\hline 8 & $2.69, \mathrm{t}(7.1)$ & $38.8, \mathrm{CH}_{2}$ & 7 & 6,7 \\
\hline 9 & & $170.9, q C$ & & \\
\hline 10 & $4.55, \mathrm{~m}$ & $54.3, \mathrm{CH}$ & $11 a, 11 b, N H(1)$ & $9,11,12$ \\
\hline $11 a$ & $2.97, \mathrm{dd}(4.7,13.7)$ & $37.9, \mathrm{CH}_{2}$ & $10,11 b$ & $9,10,12,13$ \\
\hline $11 b$ & $2.78, \mathrm{dd}(10.2,13.4)$ & & $10,11 a$ & $9,10,12,13$ \\
\hline 12 & & $137.9, \mathrm{qC}$ & & \\
\hline 13 & $7.24, \mathrm{~m}$ & $129.2, \mathrm{CH}$ & 14 & $11,13,14,15$ \\
\hline 14 & $7.24, \mathrm{~m}$ & $128.0, \mathrm{CH}$ & 13 & $12,, 13,14,15$ \\
\hline 15 & $7.16, \mathrm{~m}$ & $126.3, q C$ & 14 & 14 \\
\hline 16 & & $164.8, \mathrm{qC}$ & & \\
\hline 17 & $5.93, d(15.3)^{c}$ & $124.2, \mathrm{CH}$ & 18 & 16,19 \\
\hline 18 & $6.53, \mathrm{~m}$ & $142.9, \mathrm{CH}$ & 17,19 & $16,19,20$ \\
\hline 19 & $2.08, \mathrm{q}(6.9,14.1)$ & $31.1, \mathrm{CH}_{2}$ & 18,20 & $17,18,20,21$ \\
\hline 20 & $1.36, \mathrm{~m}^{\mathrm{c}}$ & $27.4, \mathrm{CH}_{2}$ & 19,21 & 21,22 \\
\hline 21 & $1.26, \mathrm{~m}^{\mathrm{d}}$ & $30.8, \mathrm{CH}_{2}$ & 20 & 22 \\
\hline 22 & $1.26, \mathrm{~m}^{\mathrm{c}}$ & 21.9, $\mathrm{CH}_{2}$ & 23 & $20,21,23$ \\
\hline 23 & $0.85, \mathrm{t}(6.6)$ & $13.9, \mathrm{CH}_{3}$ & 22 & 21,22 \\
\hline $\mathrm{NH}(1)$ & $8.26, d(8.3)$ & & 10 & 10,16 \\
\hline $\mathrm{NH}(2)$ & $8.26, d(8.3)$ & & 4 & 4,9 \\
\hline $\mathrm{NH}_{2}(3)$ & & & & \\
\hline
\end{tabular}


Table S17. NMR table of (S,E)-8-amino-4-((S)-3-(4-hydroxyphenyl)-2-((E)-oct-2enamido)propanamido)oct-2-enoic acid (Barnesin-L-Lysin, 16) in $\mathrm{D}_{2} \mathrm{O}$ at $26^{\circ} \mathrm{C}$

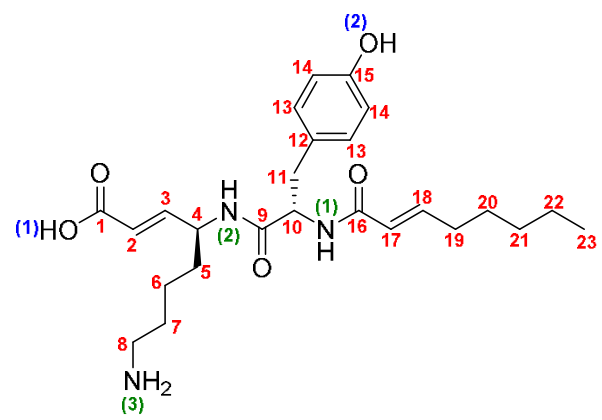

\begin{tabular}{|c|c|c|c|}
\hline position & $\delta_{\mathrm{H}}$, mult. $(\mathrm{J}$ in $\mathrm{Hz})$ & $\delta_{c}$, type $^{b}$ & COSY \\
\hline 1 & & 170.7, qC & \\
\hline 2 & $5.70, d(15.6)$ & $127.7, \mathrm{CH}$ & 3 \\
\hline 3 & $6.43, \mathrm{dd}(15.6,5.0)$ & $142.6, \mathrm{CH}$ & 2,4 \\
\hline 4 & $4.31, \mathrm{~m}$ & $49.2, \mathrm{CH}$ & 3,5 \\
\hline 5 & $1.41, \mathrm{~m}^{\mathrm{c}}$ & $33.5, \mathrm{CH}_{2}$ & 4 \\
\hline 6 & $1.26, \mathrm{~m}^{\mathrm{c}}$ & 22.3, $\mathrm{CH}_{2}$ & 7 \\
\hline 7 & $1.44, \mathrm{~m}$ & 29.3, $\mathrm{CH}_{2}$ & 8 \\
\hline 8 & $2.63, \mathrm{~m}$ & $38.8, \mathrm{CH}_{2}$ & 7 \\
\hline 9 & & 170.7, qC & \\
\hline 10 & $4.48, \mathrm{~m}$ & $54.4, \mathrm{CH}$ & $11 a, 11 b$ \\
\hline $11 a$ & $2.69, \mathrm{~m}$ & 37.0, $\mathrm{CH}_{2}$ & 10 \\
\hline $11 b$ & $2.87, \mathrm{~m}$ & & 10 \\
\hline 12 & & $127.8, \mathrm{qC}$ & \\
\hline 13 & $7.01, d(8.1)$ & $129.8, \mathrm{CH}$ & 14 \\
\hline 14 & $6.62, \mathrm{~d}(6.8)$ & $114.8, \mathrm{CH}$ & 13 \\
\hline 15 & & 155.7, qC & \\
\hline 16 & & 164.7, qC & \\
\hline 17 & $5.94, d(15.5)$ & $124.2, \mathrm{CH}$ & 18 \\
\hline 18 & $6.55, \mathrm{dt}(15.5,6.8)$ & $142.6, \mathrm{CH}$ & 17,19 \\
\hline 19 & $2.09, \mathrm{~m}$ & $31.0, \mathrm{CH}_{2}$ & 18,20 \\
\hline 20 & $1.35, \mathrm{~m}$ & 27.3, $\mathrm{CH}_{2}$ & 19 \\
\hline 21 & $1.25, \mathrm{~m}$ & $30.6, \mathrm{CH}_{2}$ & \\
\hline 22 & $1.25, \mathrm{~m}$ & 21.7, $\mathrm{CH}_{2}$ & \\
\hline 23 & & $13.6, \mathrm{CH}_{3}$ & 22 \\
\hline $\mathrm{NH}(1)$ & 7.99, m & & 10 \\
\hline $\mathrm{NH}(2)$ & 7.99, m & & 4 \\
\hline $\mathrm{NH}_{2}(3)$ & & & \\
\hline
\end{tabular}

a $600 \mathrm{MHz}$ for ${ }^{1} \mathrm{H} \mathrm{NMR,} \mathrm{COSY,} \mathrm{HSQC}$ and $\mathrm{HMBC} ; 150 \mathrm{MHz}$ for ${ }^{13} \mathrm{C} \mathrm{NMR} ;{ }^{\mathrm{b}}$ numbers of attached protons were determined by COSYd and HMBC, HSQCc. 
Table S18. NMR table of (R,E)-8-amino-4-((S)-3-(4-hydroxyphenyl)-2-((E)-oct-2enamido)propanamido)oct-2-enoic acid (Barnesin-D-Lysin, 17) in $d_{\sigma}$-DMSO at $26^{\circ} \mathrm{C}$

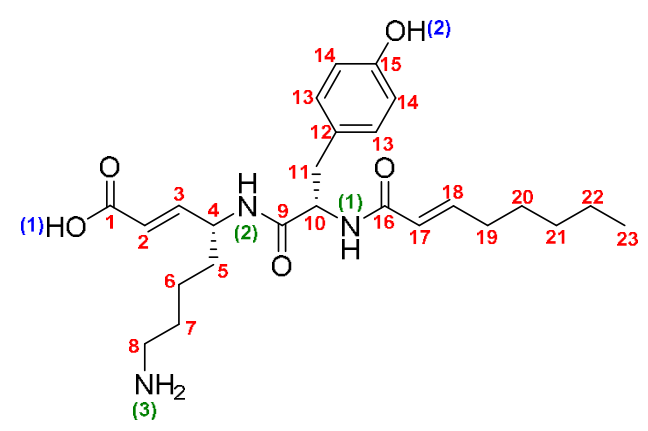

\begin{tabular}{|c|c|c|c|c|}
\hline position & $\delta_{\mathrm{H}}$, mult. $(J$ in $\mathrm{Hz})$ & $\delta_{c}$, type $^{b}$ & COSY & HMBC \\
\hline 1 & & $167.1, q C$ & & \\
\hline 2 & $5.73, \mathrm{dd}(15.7,1.5)$ & $121.2, \mathrm{CH}$ & 3 & 1,4 \\
\hline 3 & $6.70, \mathrm{dd}(15.7,5.5)$ & $147.9, \mathrm{CH}$ & 2,4 & $1,2,4,5$ \\
\hline 4 & $4.39, \mathrm{~m}^{\mathrm{c}}$ & $49.1, \mathrm{CH}$ & $5 a, 5 b, \mathrm{NH}(2)$ & $2,3,5$ \\
\hline $5 a$ & $1.57, \mathrm{~m}^{\mathrm{c}}$ & $32.8, \mathrm{CH}_{2}$ & 4 & 4,6 \\
\hline $5 b$ & $1.44, \mathrm{~m}^{\mathrm{c}}$ & & 4 & 4,6 \\
\hline 6 & $1.27, \mathrm{~m}^{\mathrm{c}}$ & $22.2, \mathrm{CH}_{2}$ & & \\
\hline 7 & $1.51, \mathrm{~m}$ & $36.6, \mathrm{CH}_{2}$ & 8 & 6,8 \\
\hline 8 & $2.75, \mathrm{t}(7.57)$ & $38.7, \mathrm{CH}_{2}$ & 7 & 6,7 \\
\hline 9 & & 171.1, qC & & \\
\hline 10 & $4.45, \mathrm{~m}$ & $54.6, \mathrm{CH}$ & $11 a, 11 b, N H(1)$ & $8,9,11$ \\
\hline $11 a$ & $2.85, \mathrm{~m}^{\mathrm{c}}$ & $37.1, \mathrm{CH}_{2}$ & $10,11 b$ & $9,10,12,13$ \\
\hline $11 b$ & $2.67, \mathrm{~m}^{\mathrm{c}}$ & & $10,11 a$ & $9,10,12,13$ \\
\hline 12 & & $127.8, q C$ & & \\
\hline 13 & $7.03, d(8.3)^{c}$ & $130.0, \mathrm{CH}$ & 14 & $11,13,14,15$ \\
\hline 14 & $6.62, d(8.3)^{c}$ & $114.9, \mathrm{CH}$ & 13 & $12,13,14,15$ \\
\hline 15 & & $155.8, q C$ & & \\
\hline 16 & & $164.8, q C$ & & \\
\hline 17 & $5.95, d(15.4)^{c}$ & $124.2, \mathrm{CH}$ & 18 & 16,19 \\
\hline 18 & $6.54, \mathrm{dt}(15.5,7.1)^{\mathrm{c}}$ & $142.9, \mathrm{CH}$ & 19,17 & $16,17,19,20$ \\
\hline 19 & $2.09, \mathrm{q}(6.8,13.93)^{\mathrm{c}}$ & $31.1, \mathrm{CH}_{2}$ & 18,20 & $17,18,20,21$ \\
\hline 20 & $1.37, \mathrm{~m}^{\mathrm{c}}$ & 27.4, $\mathrm{CH}_{2}$ & 19,21 & $18,19,22$ \\
\hline 21 & $1.25, \mathrm{~m}^{\mathrm{d}}$ & $30.8, \mathrm{CH}_{2}$ & 20 & 22 \\
\hline 22 & $1.27, \mathrm{~m}^{\mathrm{c}}$ & 21.9, $\mathrm{CH}_{2}$ & 23 & 20,23 \\
\hline 23 & $0.86, t(7.0)$ & $13.9, \mathrm{CH}_{3}$ & 22 & 21,22 \\
\hline $\mathrm{NH}(1)$ & $8.09, \mathrm{~d}(8.3)$ & & 10 & 10,16 \\
\hline $\mathrm{NH}(2)$ & $8.18, d(8.3)$ & & 4 & 4,9 \\
\hline $\mathrm{NH}_{2}(3)$ & $9.17, \mathrm{br}, \mathrm{s}$ & & & \\
\hline
\end{tabular}




\section{References}

1. Kaiser, E.; Colescott, R. L.; Bossinger, C. D.; Cook, P. I. Anal. Biochem. 1970, 34, 595-598.

2. Wu, Y.; Matsueda, G. R.; Bernatowicz, M. Synth. Commun. 1993, 23, 3055-3060.

3. Kühnel, E.; Laffan, D. D. P.; Lloyd-Jones, G. C.; Martínez del Campo, T.; Shepperson, I. R.; Slaughter, J. L. Angew. Chem. 2007, 46, 7075-7078.

4. Bastiaans, H. M. M.; van der Baan, J. L.; Ottenheijm, H. C. J. J. Org. Chem. 1997, 62, 38803889.

5. Johnson, C. R.; Zhang, B. Tetrahedron Lett. 1995, 36, 9253-9256.

6. Sun, S.; Murray, W. V, J. Org. Chem. 1999, 64, 5941-5945.

7. Carpino, L. A.; Han, G. Y. J. Org. Chem. 1972, 37, 3404-3409.

8. Sheppard, R. J. Pept. Sci. 2003, 9, 545-552.

9. Giroud, M.; Ivkovic, J.; Martignoni, M.; Fleuti, M.; Trapp, N.; Haap, W.; Kuglstatter, A.; Benz, J.; Kuhn, B.; Schirmeister, T.; Diederich, F. ChemMedChem 2017, 12, 257-270.

10. Vicik, R.; Hoerr, V.; Glaser, M.; Schultheis, M.; Hansell, E.; McKerrow, J. H.; Holzgrabe, U.; Caffrey, C. R.; Ponte-Sucre, A.; Moll, H.; Stich, A.; Schirmeister, T. Bioorg. Med. Chem. Lett. 2006, 16, 2753-2757.

11. Mallari, J. P.; Shelat, A. A.; Kosinski, A.; Caffrey, C. R.; Connelly, M.; Zhu, F.; McKerrow, J. H.; Guy, R. K. J. Med. Chem. 2009, 52, 20, 6489-6493.

12. Fujii, N.; Mallari, J. P.; Hansell, E. J.; Mackey, Z.; Doyle, P.; Zhou, Y. M.; Gut, J.; Rosenthal, P. J.; McKerrow, J. H.; Guy, R. K. Bioorg. Med. Chem. Lett. 2005, 15, 121-123.

13. Sasaki, T.; Kikuchi, T.; Fukui, I.; Murachi, T. J. Biochem. 1986, 99, 173-179.

14. Haruta, J.; Tanaka, M.; Uchida, I.; Ohta, A.; Hara, S. US005214056A, 1993, 5.

15. Hanada, K.; Tamai, M.; Yamagishi, M.; Ohmura, S.; Sawada, J.; Tanaka, I. Agric. Biol. Chem. 1978, 42, 523.

16. Sato, N.; Horiuchi, T.; Hamano, M.; Sekine, H.; Chiba, S.; Yamamoto, H.; Yoshioka, T.; Kimura, I.; Satake, M.; Ida, Y. Biosci. Biotechnol., Biochem. 1996, 60, 1747.

17. Gobec, S.; Frlan, R. Curr. Med. Chem. 2006, 13, 2309-2327.

18. Konno, H.; Kubo, K.; Makabe, H.; Toshiro, E.; Hinoda, N.; Nosaka, K.; Akaji, K. Tetrahedron 2007, 63, 9502-9513.

19. Schaschke, N. Bioorg. Med. Chem. Lett. 2004, 14, 855-857. 